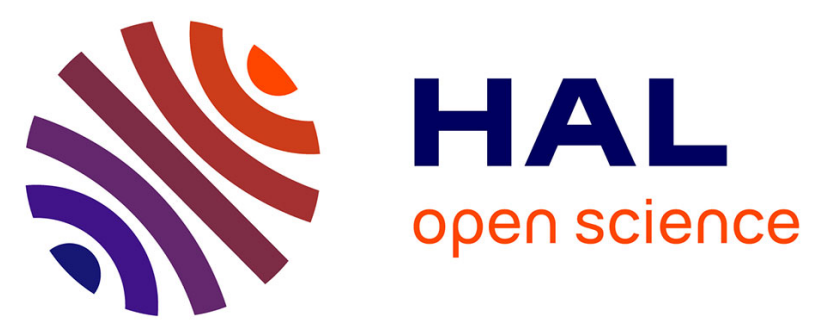

\title{
Prosthetic groups for radioiodination and astatination of peptides and proteins: a comparative study of five potential bioorthogonal labeling strategies
}

Laurent Navarro, Marion Berdal, Michel Chérel, Frédéric Pecorari, Jean-François Gestin, François Guérard

\section{To cite this version:}

Laurent Navarro, Marion Berdal, Michel Chérel, Frédéric Pecorari, Jean-François Gestin, et al.. Prosthetic groups for radioiodination and astatination of peptides and proteins: a comparative study of five potential bioorthogonal labeling strategies. Bioorganic and Medicinal Chemistry, In press, pp.167-174. 10.1016/j.bmc.2018.11.034 . inserm-01939636

\section{HAL Id: inserm-01939636 https://www.hal.inserm.fr/inserm-01939636}

Submitted on 29 Nov 2018

HAL is a multi-disciplinary open access archive for the deposit and dissemination of scientific research documents, whether they are published or not. The documents may come from teaching and research institutions in France or abroad, or from public or private research centers.
L'archive ouverte pluridisciplinaire HAL, est destinée au dépôt et à la diffusion de documents scientifiques de niveau recherche, publiés ou non, émanant des établissements d'enseignement et de recherche français ou étrangers, des laboratoires publics ou privés. 


\section{Accepted Manuscript}

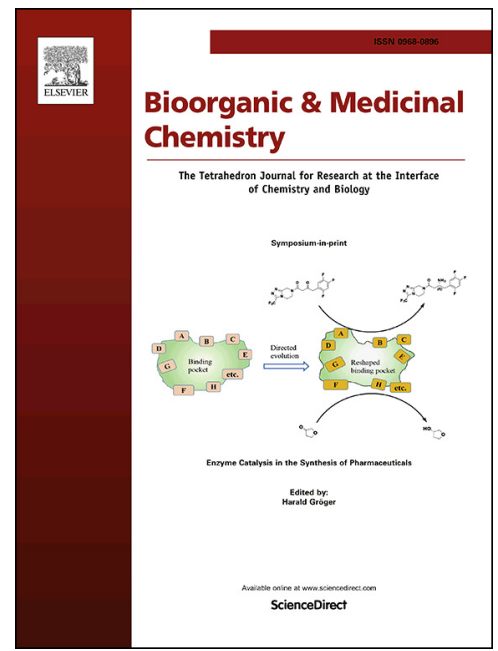

Prosthetic groups for radioiodination and astatination of peptides and proteins: a comparative study of five potential bioorthogonal labeling strategies

Laurent Navarro, Marion Berdal, Michel Chérel, Frédéric Pecorari, JeanFrançois Gestin, François Guérard

PII: S0968-0896(18)31610-9

DOI: https://doi.org/10.1016/j.bmc.2018.11.034

Reference:

BMC 14638

To appear in:

Bioorganic \& Medicinal Chemistry

Received Date:

20 September 2018

Revised Date:

22 November 2018

Accepted Date:

24 November 2018

Please cite this article as: Navarro, L., Berdal, M., Chérel, M., Pecorari, F., Gestin, J-F., Guérard, F., Prosthetic groups for radioiodination and astatination of peptides and proteins: a comparative study of five potential bioorthogonal labeling strategies, Bioorganic \& Medicinal Chemistry (2018), doi: https://doi.org/10.1016/j.bmc. 2018.11.034

This is a PDF file of an unedited manuscript that has been accepted for publication. As a service to our customers we are providing this early version of the manuscript. The manuscript will undergo copyediting, typesetting, and review of the resulting proof before it is published in its final form. Please note that during the production process errors may be discovered which could affect the content, and all legal disclaimers that apply to the journal pertain. 


\title{
Prosthetic groups for radioiodination and astatination of peptides and proteins: a comparative study of five potential bioorthogonal labeling strategies
}

\author{
Laurent Navarro, Marion Berdal, Michel Chérel, Frédéric Pecorari, Jean-François Gestin*, \\ François Guérard*
}

CRCINA, Inserm, CNRS, Université d'Angers, Université de Nantes, Nantes, France

\begin{abstract}
I}$ - and ${ }^{211}$ At-labeled azide and tetrazine $(\mathrm{Tz})$ based prosthetic groups for bioorthogonal conjugation were designed and tested in a comparative study of five bioorthogonal systems. All five bioconjugation reactions conducted on a model clickable peptide led to quantitative yields within less than a minute to several hours depending on the system used. Transferability to the labeling of an $\mathrm{IgG}$ was demonstrated with one of the bioorthogonal system. This study provides several new alternatives to the conventional and suboptimal approach currently in use for radioiodination and astatination of biomolecules and should accelerate the development of new probes with these radionuclides for applications in nuclear imaging and targeted alpha-therapy.
\end{abstract}

\section{Introduction}

Heavy radiohalogens astatine and iodine have been increasingly studied over the past decades for therapeutic or diagnostic purpose in nuclear medicine. ${ }^{1}$ The most relevant iodine radioisotopes - ${ }^{123} \mathrm{I}\left(\mathrm{\gamma}, \mathrm{t}_{1 / 2}=13.2\right.$ hours $),{ }^{124} \mathrm{I}\left(\beta^{+}, \mathrm{t}_{1 / 2}=4.18\right.$ days $),{ }^{125} \mathrm{I}\left(\mathrm{\gamma}\right.$, Auger $\mathrm{e}^{-}, \mathrm{t}_{1 / 2}=59.4$ days) and ${ }^{131} \mathrm{I}$ ( $\beta^{-}$and $\gamma, \mathrm{t}_{1 / 2}=8$ days) - can be used for imaging and/or therapy depending on the radiation they emit upon decay, whereas ${ }^{211} \mathrm{At}\left(\mathrm{t}_{1 / 2}=7.2 \mathrm{~h}, \alpha\right.$-emitter $)$ is a promising isotope for the treatment of small cell clusters or isolated tumor cells. ${ }^{2,3}$ The radioiodination strategy of relevant peptides and proteins has long been the direct electrophilic substitution on tyrosine. Despite the advantage of being a fast and simple procedure, this method exhibits limits for in vivo applications due to rapid deiodination that leads to radioiodine activity uptake in non-targeted organs (especially in thyroid and stomach). Consequently, more stable labeling strategies based on the use of a radioiodinated agent for acylation of lysine residues have been developed since then to overcome this issue. ${ }^{4,5}$ The lack of sufficient stability of direct electrophilic labeling with astatine is even more marked, ${ }^{6}$ and in this case, the use of an astatinated prosthetic group is essential to carry out any in vitro or in vivo experimentation. Thus, several astatinated agents have also been developed for conjugation to amino groups of lysine residues ${ }^{7,8}$ or more recently to cysteine ${ }^{9}$ in order to obtain sufficient label stability for biological experimentations.

The most used prosthetic groups to date are $N$-succinimidyl-3-[*I]iodobenzoate ([*I]SIB) or $N$ succinimidyl-3-[ $\left[{ }^{111} \mathrm{At}\right]$ astatobenzoate $\left(\left[{ }^{211} \mathrm{At}\right] \mathrm{SAB}\right)$ which are comprised of an activated ester for conjugation to the lysine residues of proteins. The conjugation step requires a mildly basic aqueous solution $(\mathrm{pH} \approx 8.5)$ to make the amino group sufficiently reactive with the activated ester. However, competitive hydrolysis of the ester also occurs at this $\mathrm{pH}$, leading to the 
production of the inactive benzoate side product and to suboptimal conjugation yields (Figure 1a). In the most favorable cases, relatively good conjugation yields can be obtained by this approach (up to $75-80 \%$ on an intact $\mathrm{IgG}$ as reported by us recently ${ }^{10}$ ) but a minimum protein concentration of $4-5 \mathrm{mg} / \mathrm{mL}$ is necessary to favor lysine conjugation over competitive hydrolysis, a concentration that is not always compatible with antibodies at this $\mathrm{pH}$ due to aggregation and precipitation issues and which also limits the achievable specific activity.

Recent developments in bioorthogonal click chemistry offer a growing choice of strategies to conjugate tags with high yields and specificity with biomolecules pre-modified with a complementary bioorthogonal handle. The strength of this chemistry is that it relies on the inertness or low reactivity of bioorthogonal functionalities with aqueous media and chemical groups naturally encountered in biological material. ${ }^{11}$ It allows theoretically the bioconjugation of clickable tags within a short time with quantitative yields (Figure 1b). Click ligation of radioactive tags on various biomolecules are also the object of an important research effort to provide new strategies for labeling with radioisotopes that require fast, simple and efficient procedures that are difficult to reach by conventional chemistry. ${ }^{12}$

a) conventional lysine conjugation (ref 10)

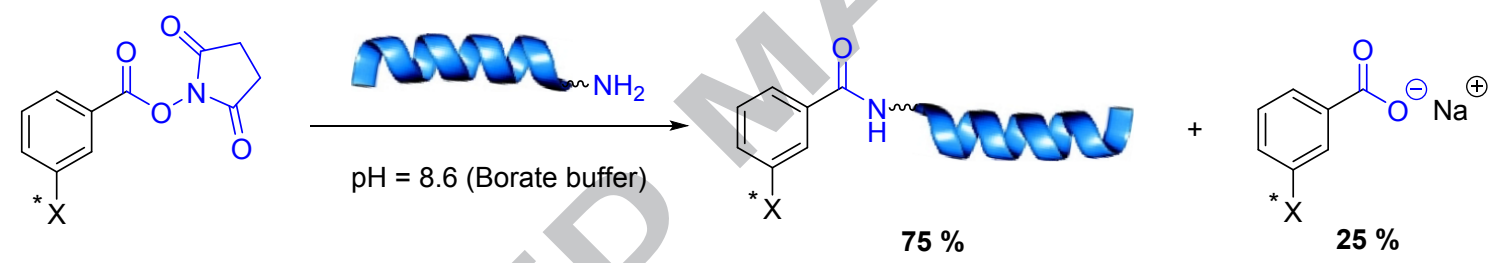

b) bioorthogonal conjugation (this work)

inactive benzoate side product
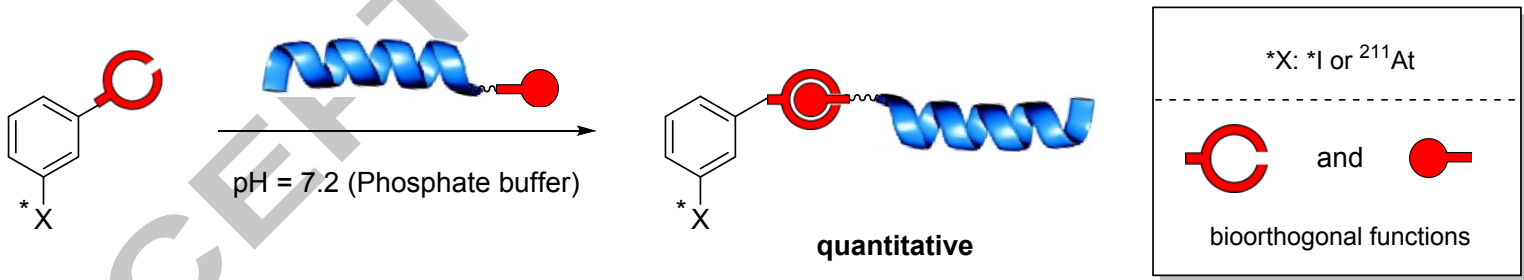

Figure 1. Bioconjugation strategies to form radiohalogenated proteins.

Recent reports have proposed the use of bioorthogonal chemistry for radioiodination of peptides or proteins with clickable prosthetic groups including the strain-promoted alkyneazide cycloaddition (SPAAC) ${ }^{13,14}$ and the inverse electron demand Diels Alder cycloaddition (IEDDA) reactions, ${ }^{15,16}$ but to our knowledge, such strategy has not yet been reported for astatination. Yet, the necessity of fast, simple and quantitative yielding labeling procedure is even more essential for astatination with ${ }^{211} \mathrm{At}$ because of its availability in low amounts, its shorter physical half-life compared to relevant iodine radioisotopes, and the marked radiolysis issues due to the astatine decay limiting the starting activity that can be engaged in a radiolabeling procedure, ${ }^{17}$ for the preparation of radiopharmaceuticals for clinical use, or even for animal studies. 
In this context, we report herein the comparison of three or the most popular bioorthogonal reactions that we have adapted to the context of peptide or protein radiolabeling with iodine and astatine: i) the copper catalyzed alkyne azide cycloaddition (CuAAC), ii) the SPAAC, and iii) the IEDDA between tetrazines and strained alkynes or strained alkenes. On one hand, clickable radioiodinated and astatinated prosthetic groups bearing a tetrazine or an azide bioorthogonal handle were designed and synthesized from corresponding aryliodonium salts. As reported recently, aromatic nucleophilic substitution $\left(\mathrm{S}_{\mathrm{N}} \mathrm{Ar}\right)$ with aryliodonium salts is an efficient strategy for the radiohalogenation of an aryl position, especially with astatine, since it is more robust than electrophilic pathways, and that purifications of labeled compounds are simplified. ${ }^{10,18}$ On the other hand, a simple tripeptide that was comprised of a lysine between two protected glycines was synthesized and conjugated via the amino group of the lysine to four bioorthogonal handles: i) a terminal alkyne for $\mathrm{CuAAC}$, ii) a dibenzoazacyclooctyne (DIBAC) for SPAAC with azides (DIBAC/N $\left.\mathrm{N}_{3}-\mathrm{SPAAC}\right)$, iii) a bicyclononyne (BCN) for either SPAAC with azide (BCN/N ${ }_{3}$-SPAAC) or IEDDA with Tz (BCN/Tz-IEDDA) or iv) a transcyclooctene (TCO) for IEDDA with Tz (TCO/Tz-IEDDA) (Figure 2). The purpose was to identify the most adapted systems based on the following criteria: ease of access to the labeled clickable prosthetic groups, simplicity of execution, kinetics and yield of the bioorthogonal ligation. Results obtained herein on a model peptide are discussed in the perspective of protein radioiodination and astatination.

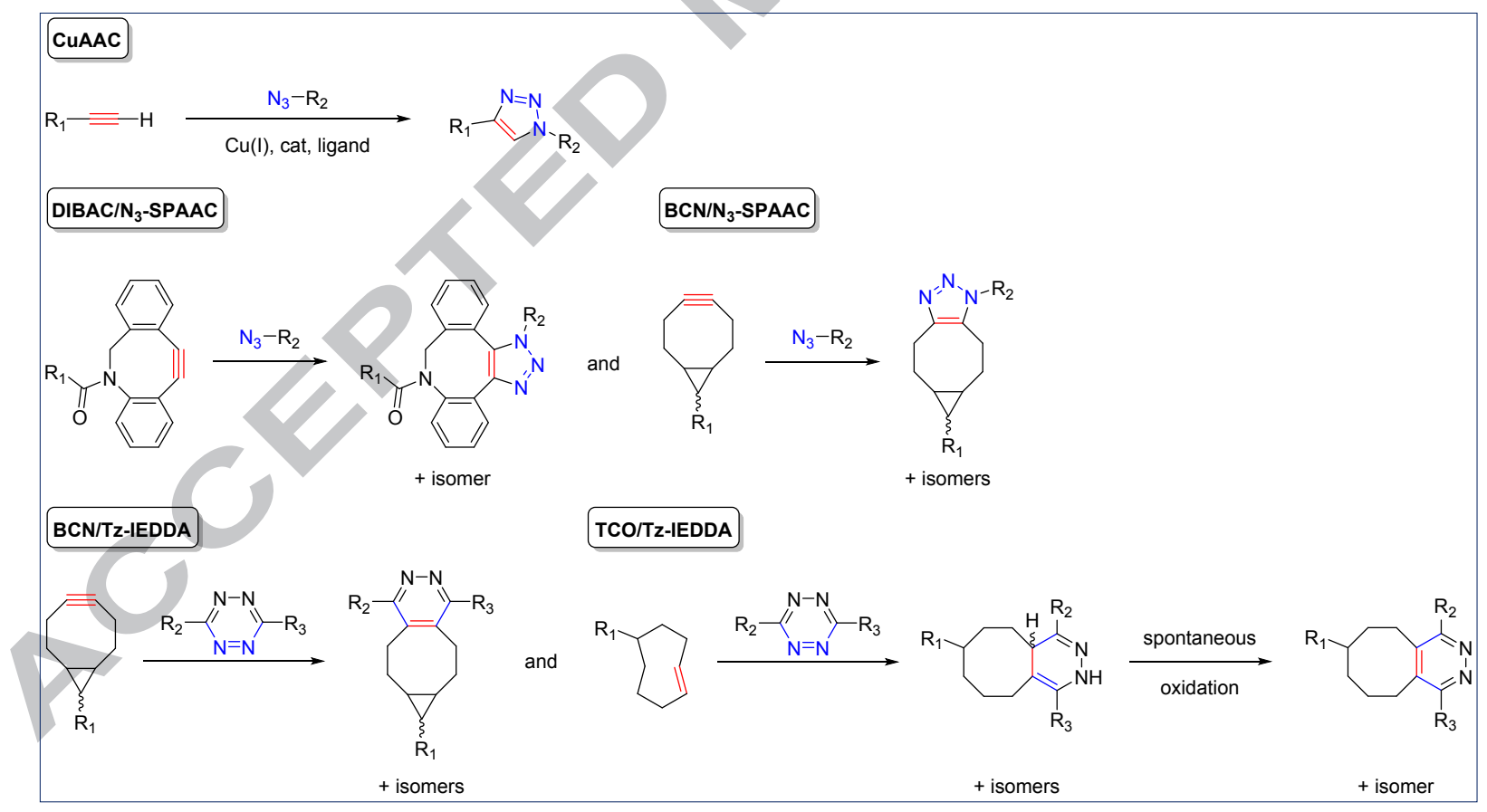

Figure 2. Bioorthogonal reactions evaluated in this report. 


\section{Results and discussion}

\subsection{Synthesis}

Bifunctional precursors. In order to investigate CuAAC, SPAAC and IEDDA strategies, bifunctional precursors were designed as small aromatic compounds with functionalities allowing on one hand the substitution by the radiohalogen by $\mathrm{S}_{\mathrm{N}} \mathrm{Ar}$, and on the other hand the bioorthogonal ligation by one of the five reactions investigated. Aryliodonium tosylates were generated in the last synthesis step by oxidation of the corresponding iodoarenes with $m$ CPBA followed by electrophilic substitution with anisole in the presence of tosic acid. The benzylazide iodonium precursor 3 was obtained in good yield whereas in the case of the tetrazine, no iodonium could be formed in sufficient yield for isolation by this approach, probably because of the strong deactivation of the aromatic ring. An alternative approach by oxidative diacetoxylation using Selectfluor ${ }^{\circledR}$ reported recently by Qin et al ${ }^{19}$ provided the expected compound 4 in moderate (36\%) but sufficient yield (Scheme 1 ).

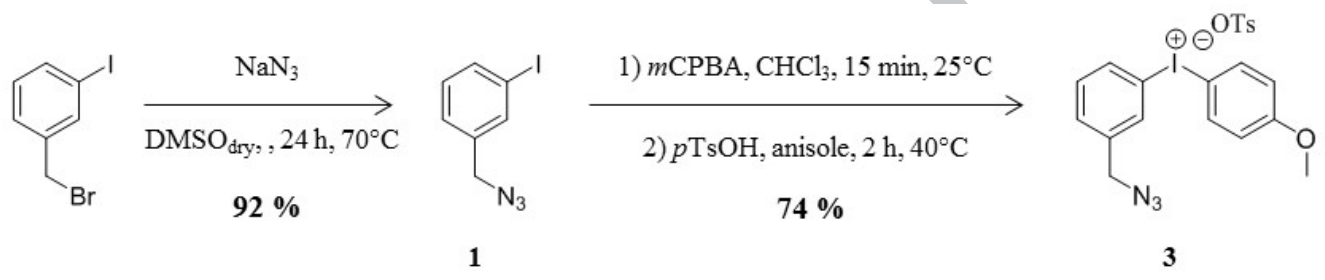

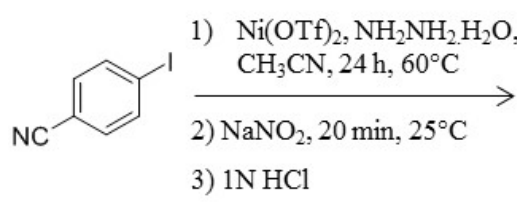

$18 \%$

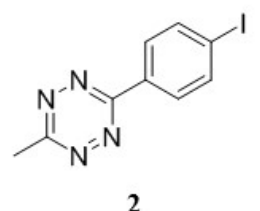

2

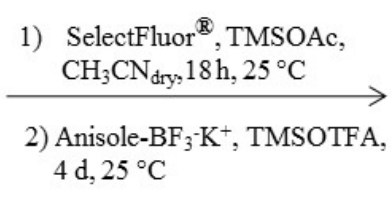

$36 \%$

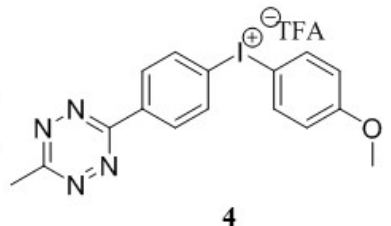

4

Scheme 1. Synthesis of bifunctional aryliodonium precursors.

Clickable model peptides and cold iodinated references. For the comparative study of the different bioorthogonal strategies investigated, we chose to synthesize a simple tripeptide consisting in a lysine between two protected glycines (peptide 9). It was prepared by conventional peptide synthesis methods as a triflate salt of the free amino group (synthetic details in ESI). This peptide was designed as the most simple way to mimic a lysine on which bioconjugation by acylation is usually performed on proteins.

Four bioorthogonal groups complementary to the azide or to the tetrazine groups were then conjugated, resulting in clickable peptides $14,15,16,17$ conjugated respectively to a terminal alkyne for CuAAC with the azide, TCO for TCO/Tz-IEDDA, DIBAC for DIBAC/ $\mathrm{N}_{3}-$ SPAAC, or $\mathrm{BCN}$ for $\mathrm{BCN} / \mathrm{N}_{3}$-SPAAC or $\mathrm{BCN} / \mathrm{Tz}-\mathrm{IEDDA}$, with yields ranging from 74 to $83 \%$.

All four clickable peptides where then subjected to cycloaddition with the cold iodinated benzylazide 1 and/or methylphenyltetrazine 2. Conversion was quantitative, resulting in five cold clicked peptides 18, 19, 20, 21, 22 with yields ranging from 32 to $85 \%$ after chromatographic purification and that were used as references for chromatographic analysis with their radioiodinated and astatinated analogues (Scheme 2, synthetic details given in ESI). 

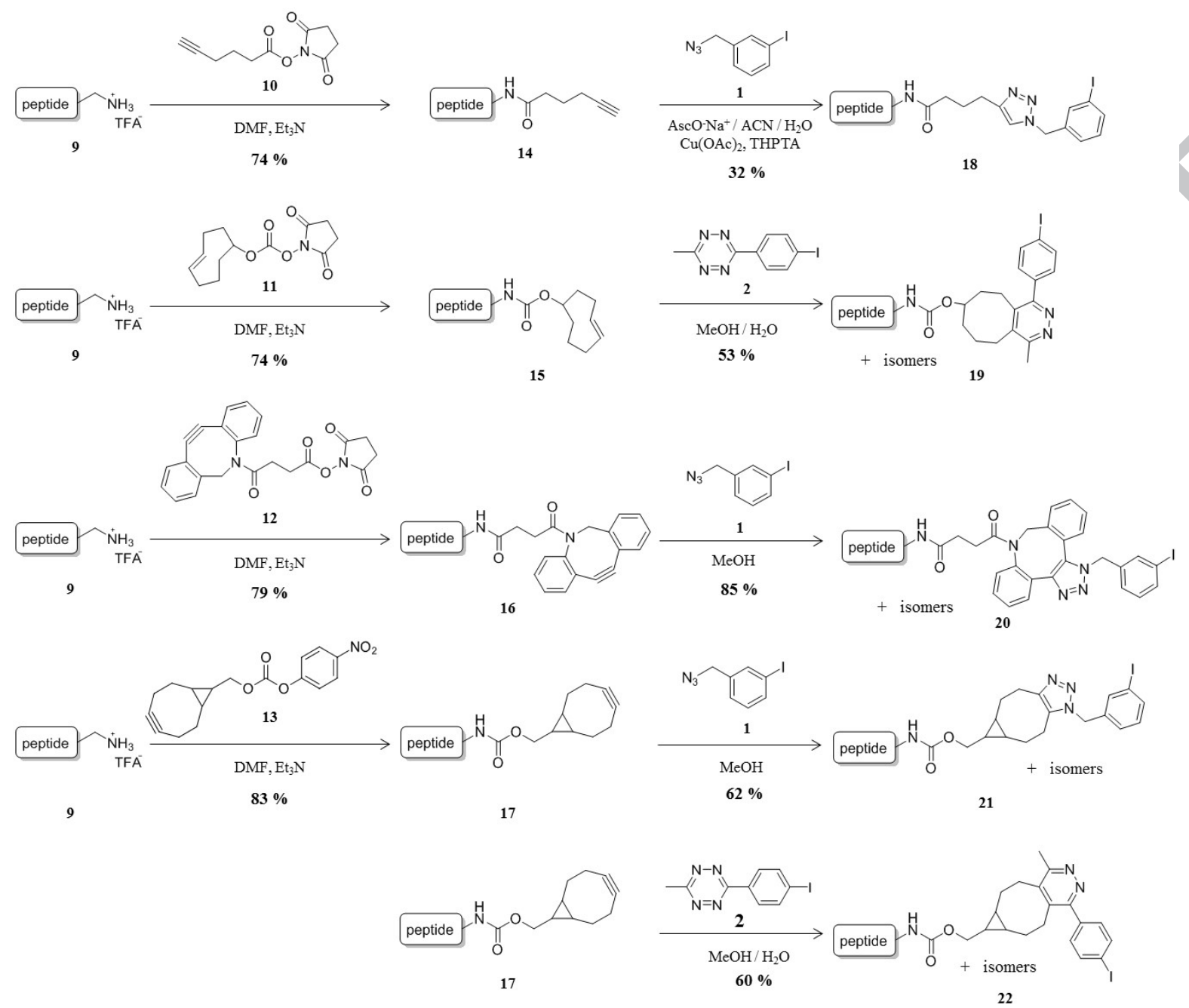

Scheme 2. Synthesis of clickable model peptides and corresponding cold iodinated clicked references. AscONa = sodium ascorbate; THPTA $=$ Tris(3-hydroxypropyltriazolylmethyl)amine .

2.2. Radiochemistry

Labeling study of both iodonium precursors 3 and $\mathbf{4}$ with ${ }^{125} \mathrm{I}$ and ${ }^{211}$ At was performed starting from conditions determined previously with other aryliodonium salts, i.e., in acetonitrile with heating for $30 \mathrm{~min},{ }^{18}$ leading to the formation to the expected clickable radiohalogenated products $(\mathbf{1} \mathbf{a}, \mathbf{1} \mathbf{b}, \mathbf{2} \mathbf{a}, \mathbf{2 b})$ in association with a small ratio of the radiohalogenoanisole side product $\mathbf{0 a} / \mathbf{0 b}$ (Scheme 3). 


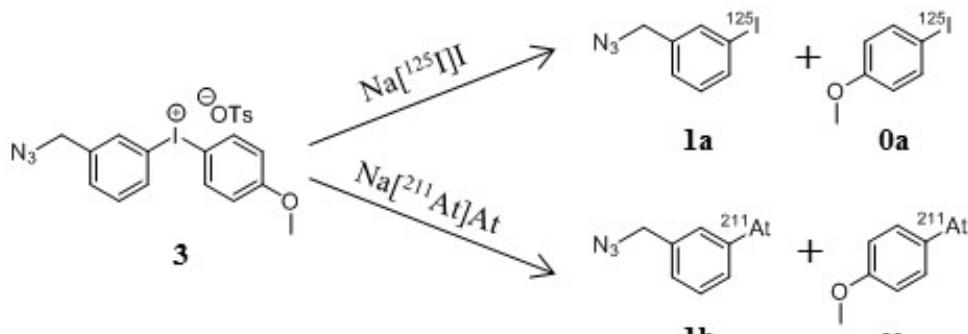

lb

ob

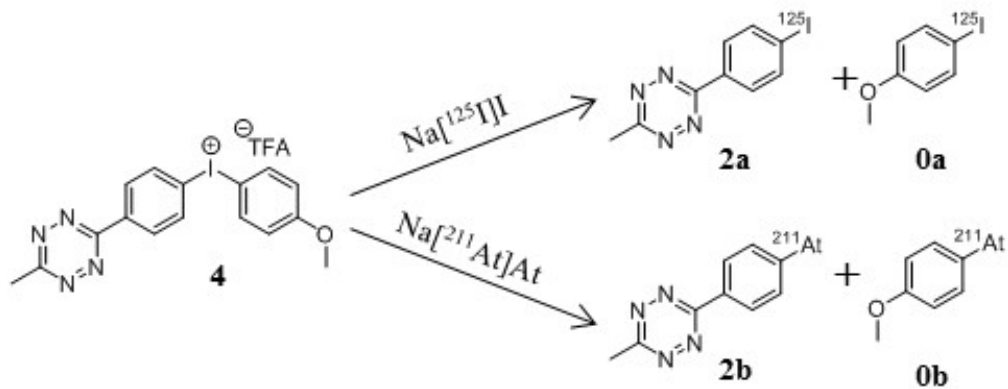

Scheme 3. Radioiodination and astatination of aryliodonium precursors 3 and 4 .

Similar to our previous reports, ${ }^{18,10}$ astatide was significantly more reactive than iodide, with lower temperatures required to reach a quantitative conversion, and a regioselectivity of substitution somewhat lower than for radioiodination (Table 1). For the synthesis of the astatinated azide derivative $\mathbf{1 b}$, the RCY was improved by changing the solvent to methanol ( $86 \%$ at $80^{\circ} \mathrm{C}$ instead of $73 \%$ in $\mathrm{CH}_{3} \mathrm{CN}$ ). Again, improved $\mathrm{RCY}$ in methanol is typical with astatide whereas this solvent inhibits the reaction with iodide. ${ }^{10}$ Due to the higher activation of the aryl substituted with the methyltetrazine, lower temperatures were required to form $\mathbf{2 a}$ and $\mathbf{2 b}$ and better regioselectivities were achieved.

Table 1. Influence of the temperature on the radiolabeling yield (RCY) of aryliodonium salts 3 and 4 reacted for 30 min with $\mathrm{Na}\left[{ }^{125} \mathrm{I}\right] \mathrm{I}$ or $\mathrm{Na}\left[{ }^{211} \mathrm{At}\right] \mathrm{At}$ in $\mathrm{CH}_{3} \mathrm{CN}$. RCYs based on HPLC analyses of the crude products.

\begin{tabular}{clcccc}
\multirow{2}{*}{ Precursor } & \multirow{2}{*}{$\left({ }^{\circ} \mathrm{C}\right)$} & \multicolumn{2}{c}{${ }^{125} \mathrm{I}(\mathrm{RCY} \%)$} & \multicolumn{2}{c}{${ }^{211} \mathrm{At}(\mathrm{RCY} \%)$} \\
\cline { 3 - 6 } & & $\mathbf{1 a}$ or 2a & $\mathbf{0 a}$ & $\mathbf{1 b}$ or 2b & $\mathbf{0 b}$ \\
\hline \multirow{3}{*}{3} & 60 & - & - & 58 & 9 \\
& 80 & 20 & 2 & $73 / 86^{\mathrm{a}}$ & $14 / 13^{\mathrm{a}}$ \\
& 100 & 63 & 4 & - & - \\
& 120 & 82 & 7 & - & - \\
\hline \multirow{3}{*}{4} & 40 & - & - & 86 & 11 \\
& 60 & 20 & 1 & 85 & - \\
& 80 & 60 & 2 & - & - \\
\hline
\end{tabular}

a Solvent $=$ methanol

Purification of the azide derivatives 1a and $\mathbf{1 b}$ was simple and fast and consisted in an evaporation of the labeling mixture to dryness followed by an extraction with diethyl ether. 
Precursor 3 being insoluble in this solvent, only the product and the side products $\mathbf{0 a} / \mathbf{0 b}$ were extracted. After a new evaporation to dryness, chromatographic analysis indicated the presence of 1a or $\mathbf{1 b}$ only, the anisole derivative being evaporated during the drying step (See radiochromatograms in ESI). Overall, 1a and 1b were obtained with a RCY of $65 \pm 5 \%$ and $64 \pm 6 \%$ respectively. Due to the low but non-negligible solubility of iodonium salt 4 in $\mathrm{Et}_{2} \mathrm{O}$, the same purification method could not be used. In this case, $\mathbf{2} \mathbf{a}$ and $\mathbf{2} \mathbf{b}$ were recovered by filtration on a short silica cartridge on which the iodonium salt was retained when using AcOEt as eluent. 2a and $\mathbf{2 b}$ were obtained as mixtures with anisole derivatives $\mathbf{0 a}$ and $\mathbf{0 b}$, respectively, which were again eliminated during the subsequent evaporation step, providing $\mathbf{2 a}$ and $\mathbf{2 b}$ with RCY of $71 \pm 5 \%$ and $76 \pm 4 \%$.

\subsection{Bioorthogonal conjugation}

The four clickable peptides $(14,15,16,17)$ and the two radioiodinated or astatinated clickable compounds $\mathbf{1 a / 1} \mathbf{b}$ and $\mathbf{2 a / 2 b}$ resulted in five bioorthogonal combinations (Scheme 4) whose reaction kinetics and yields were compared. In order to get an estimate of yields and kinetics that would be obtained when labeling relevant biomolecules such as a monoclonal antibody (mAb), we chose to fix the peptide concentration at $200 \mu \mathrm{M}$ in phosphate-buffered saline (PBS). Such a concentration would be, in terms of bioorthogonal handles concentration, the equivalent of a $5 \mathrm{mg} / \mathrm{mL} \mathrm{mAb}$ grafted with 6 bioorthogonal handles per $\mathrm{mAb} .5 \mathrm{mg} / \mathrm{mL}$ is in the range of concentration usually required to perform conventional bioconjugation of radiohalogenated prosthetic groups on $\mathrm{mAb}$ lysine residues. ${ }^{20,21} \mathrm{We}$ have thus hypothesized that if high bioorthogonal ligation RCYs (i.e. $>75 \%$ ) could be obtained with $200 \mu \mathrm{M}$ peptide as initial condition, similar results could be reachable with at least $5 \mathrm{mg} / \mathrm{mL} \mathrm{mAb}$. This would then mean that this approach is potentially at least as good as the conventional one in terms of resulting specific activity and amount of starting mAb needed, or even better if lower mAb concentrations can be also used. 


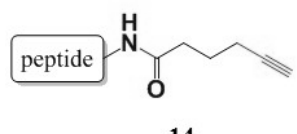

14

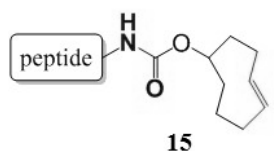

15
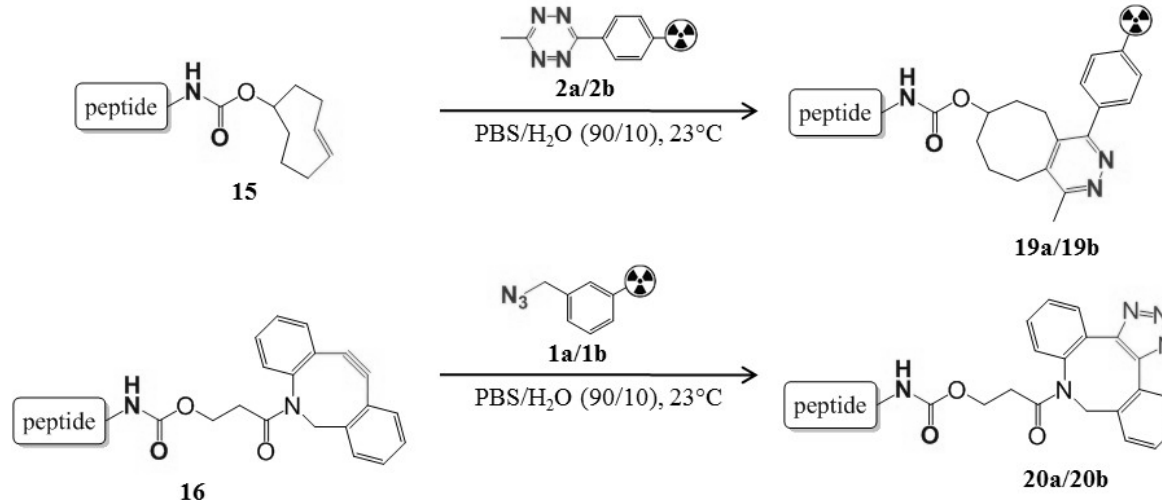

$18 \mathbf{a} / \mathbf{1 8 b}$

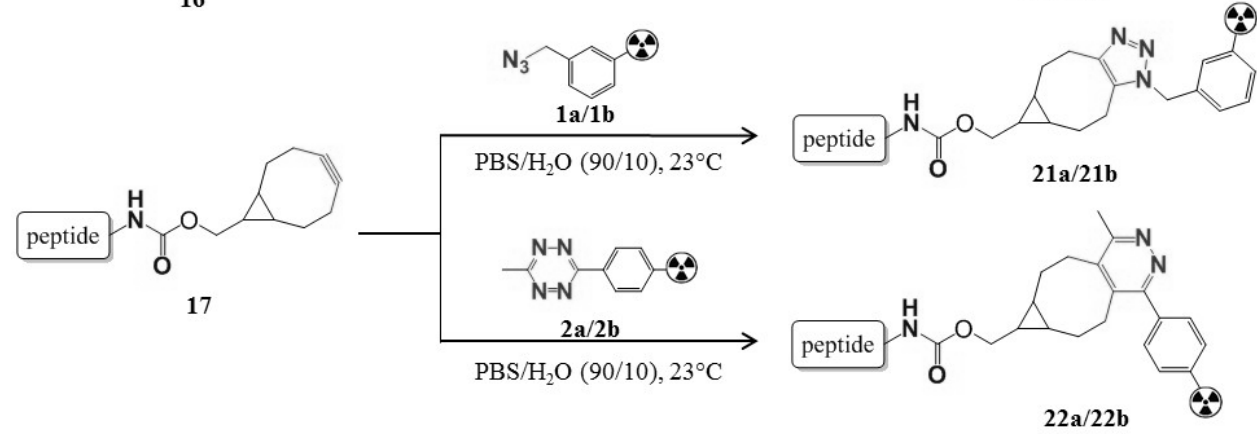

Scheme 4. Conjugation of radiohalogenated clickable prosthetic groups with model clickable peptides. AscONa $=$ sodium ascorbate; THPTA $=$ Tris(3-hydroxypropyltriazolylmethyl)amine.

Interestingly, all of the 5 bioorthogonal systems lead to RCYs $>99 \%$ with the radioiodinated and the astatinated compounds (Figure 3). As expected the TCO/Tz-IEDDA system was the fastest, providing quantitative RCYs within less than a minute. After optimization of the conditions ( $\mathrm{Cu}^{+}$and THPTA ligand concentrations) the CuAAC between peptide 14 and azides 1a or $\mathbf{1 b}$ was the second fastest system with quantitative yields within $5-10 \mathrm{~min}$ followed by the BCN/Tz-IEDDA reaction between peptide 17 and the Tz-labeled compounds 2a and 2b (RCY > 99\% after 10-15 min). The DIBAC/ $\mathrm{N}_{3}-\mathrm{SPAAC}$ and $\mathrm{BCN} / \mathrm{N}_{3}-\mathrm{SPAAC}$ reactions between azides $(\mathbf{1} \mathbf{a} / \mathbf{1 b})$ derivatives and peptides 16 and 17 provided the slowest kinetics with RCY $>99 \%$ reached after respectively 45-60 min and several hours. 
$\mathrm{I}-125$

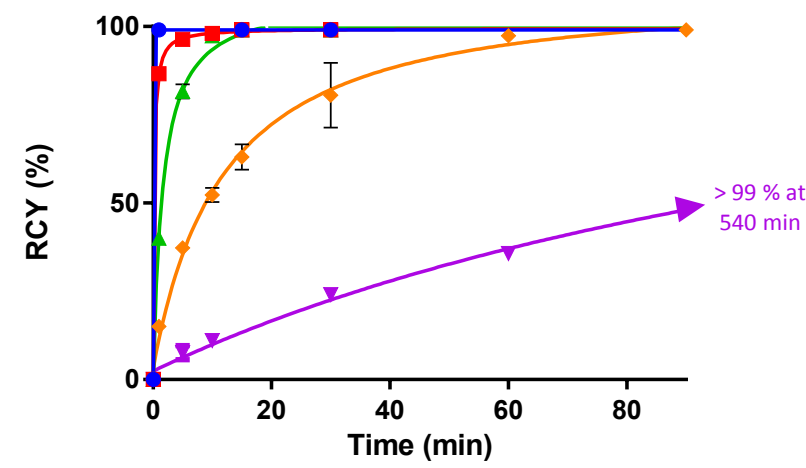

At-211

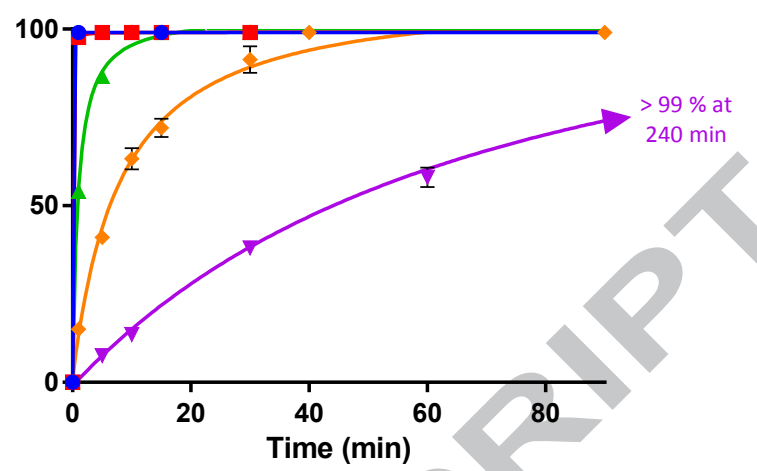

Figure 3. Kinetics of bioorthogonal conjugation between clickable peptides and radiohalogenated prosthetic groups $(\mathrm{n}=3)$ : $\mathrm{CuAAC}(\boldsymbol{\bullet})$; DIBAC/N $3-\mathrm{SPAAC}(\bullet)$; $\mathrm{BCN} / \mathrm{N}_{3}-$ SPAAC $(\boldsymbol{\nabla})$; BCN/Tz-IEDDA $(\boldsymbol{\Delta})$; TCO/Tz-IEDDA $(\bullet)$. RCYs based on the HPLC analysis of the crude product.

Surprisingly, the cycloaddition reactions performed faster with astatinated compounds than with radioiodinated ones. Although not clearly visible in the fastest reactions, it was particularly marked in the $\mathrm{BCN} / \mathrm{N}_{3}$-SPAAC system with a reaction $\mathrm{t}_{1 / 2} \approx 110 \mathrm{~min}$ with radioiodine and $\mathrm{t}_{1 / 2} \approx 45 \mathrm{~min}$ with astatine. We investigated if the difference of lipophilicity between the iodinated and the astatinated compounds could be the origin of the kinetics differences since it has been reported previously that lipophilicity of reagents can have an impact on cycloaddition reaction rates performed in aqueous medium, with higher kinetics for the most lipophilic compounds that are forced into close proximity by hydrophobic interactions between reagents. ${ }^{22}$ Partition coefficients in water/octanol were thus determined for compounds 1a and 1b (procedure details in ESI). Although the lipophilicity of the astatinated compound was as expected the highest $(\log \mathrm{P}=2.47 \pm 0.03)$, the difference with the radioiodinated one $(\log \mathrm{P}=2.38 \pm 0.05)$ was not significant enough to comfort this hypothesis. Given the very high dilution of astatinated species used in this kinetic study (about $1 \mathrm{MBq} / 100 \mu \mathrm{L} \approx 0.01 \mathrm{ppb}$ ), catalysis by trace impurities associated to the ${ }^{211} \mathrm{At}$ production or generated by radiolysis of the solvent by the highly ionizing $\alpha$-decay may have contributed to the accelerated kinetics with compound $\mathbf{1 b}$.

Overall, four out of the five tested bioconjugation systems exhibited reaction kinetics and RCYs compatible with the use of radioiodine isotopes and especially with the relatively short half-life of ${ }^{211} \mathrm{At}\left(\mathrm{BCN} / \mathrm{N}_{3}\right.$-SPAAC being too slow). However, the fastest may not necessarily be the best. Indeed, while TCO/Tz-IEDDA provided quantitative cycloaddition yields within few seconds, it resulted in two dihydropyrazine tautomers that converted spontaneously within several hours to the corresponding aromatic pyrazine (see representative radiochromatograms in ESI), a phenomenon that has been reported previously with similar compounds. ${ }^{16,23}$ This may raise concern regarding the lack of homogeneity of the resulting radiopharmaceutical and the consequence on pharmacokinetics, in vivo degradation of the conjugation bonds and on the carbon-radiohalogen bond stability. On the other hand, CuAAC, the second fastest system, provides the advantage of requiring fewer atoms than other systems ( 2 carbon and 3 nitrogen atoms), and resulting in a more hydrophilic product, a triazole core 
found in many naturally occurring biological compounds. It is thus expected that the risk of altering the in vivo behavior of the resulting radioimmunoconjugate should be lower than with other tested systems. It must however be kept in mind that the presence of copper, and especially $\mathrm{Cu}(\mathrm{I})$ species, in the reaction media potentially generates reactive oxygen species able to alter peptides and proteins by oxidative side reactions even when a stabilizing ligand is used to lower the $\mathrm{Cu}(\mathrm{I})$ concentration required. ${ }^{24}$ Extensive optimization may thus in some case be necessary to achieve high RCYs with preservation of the biomolecule activity.

While these bioorthogonal systems were tested on a model peptide, we wanted to probe if the results obtained could be straightforwardly transferred to the labeling of relevant macromolecules such as antibodies. For this, the $9 \mathrm{E} 7.4 \mathrm{IgG}$, a mAb developed by our group and directed against murine CD138 for targeting multiple myeloma cells ${ }^{25}$ was modified by bioconjugation with a DIBAC derivative (DBCO-NHS ester) via its lysine residues. The resulting DIBAC-9E7.4 was then subjected to incubation with the astatinated azido derivative 1b. With only $0.21 \pm 0.05$ DIBAC grafted per mAb, DIBAC concentration in solution was significantly lower than in peptide study $(3 \mu \mathrm{M}$ with $2.3 \mathrm{mg} / \mathrm{mL} \mathrm{mAb}$ vs $200 \mu \mathrm{M}$ with the model peptide). Yet, the reaction proceeded similarly to our model with a high RCY of $90 \%$ within less than $40 \mathrm{~min}$ at room temperature. The immunoreactive fraction $(82 \pm 5 \%)$ was similar to results obtained when astatination of this $\mathrm{mAb}$ is performed by the classical lysine acylation approach $(86 \pm 2 \%){ }^{10}$ This preliminary test on a biologically relevant biomolecule is a good indication that the different systems described in this study on a model peptide should be easily transferable for further biological investigation.

\section{Conclusion}

Bioorthogonal chemistry has been applied to an increasing number of biomedical applications and can provide new solutions to old problems. Meanwhile, it appears necessary to investigate alternative approaches to the conventional bioconjugation reactions developed three decades ago for labeling proteins and peptides with radioiodine and astatine. However, given the plethora of bioorthogonal system developed over the past decade, a selection and a comparison of such systems appeared necessary to us before developing specific tracers labeled by such a strategy. We showed that of the five systems tested, all provided quantitative RCYs on a model peptide, with four of them in a reasonably short time in the perspective of peptides or proteins labeling with ${ }^{211} \mathrm{At}\left(\mathrm{t}_{1 / 2}=7.2 \mathrm{~h}\right)$. The choice of the optimal system will depend on the biomolecule to be labeled. Despite its impressive reaction kinetics, the TCO/Tz-IEDDA may lead to inhomogeneous product, the CuAAC has the advantage of leading to a more biocompatible ligation product (a triazole) with very fast kinetics, but the presence of copper may also be a concern regarding degradation of biomolecules to be labeled. Finally the BCN/Tz-IEDDA and the DIBAC/N ${ }_{3}$-SPAAC might be the best compromise in several situations since, despite the slower but still largely acceptable reaction kinetics for labeling with radioiodine or ${ }^{211} \mathrm{At}$, the limits cited above are not observed. Further developments with relevant targeting biomolecules are warranted with a specific care on their in vivo fate (impact on biodistribution and radiolabeling stability). Such results will be reported in due course. 


\section{Experimental section}

\subsection{Synthesis}

\subsubsection{General.}

All reagents and solvents were obtained commercially and used without further purification unless otherwise noted. 3-iodobenzylazide (1) and 3-(4-iodophenyl)-6-methyl-1,2,4,5tetrazine (2) were obtained by the method described respectively by Chun et $\mathrm{al}^{26}$ and Yang et al. ${ }^{27}$ respectively. ${ }^{1} \mathrm{H},{ }^{19} \mathrm{~F}$ and ${ }^{13} \mathrm{C}$ NMR spectra were recorded with a Bruker AC spectrometer at $400\left({ }^{1} \mathrm{H}\right), 376\left({ }^{19} \mathrm{~F}\right)$ and $100\left({ }^{13} \mathrm{C}\right) \mathrm{MHz}$. Chemical shifts $(\delta)$ are reported in part per million (ppm) relative to tetramethylsilane (TMS) and residual solvent $\left(\mathrm{CDCl}_{3}: 7.26 \mathrm{ppm}, \mathrm{DMSO}-d_{6}\right.$ : $2.50 \mathrm{ppm}, \mathrm{CD}_{3} \mathrm{CN}: 1.94 \mathrm{ppm}$ ). The multiplicity is described by the symbols s (singlet), $\mathrm{d}$ (doublet), $\mathrm{t}$ (triplet), $\mathrm{q}$ (quartet), dt (doublet of triplet) and $\mathrm{m}$ (multiplet). Reactions were monitored by thin-layer chromatography (TLC) using $60 \mathrm{~F}_{254}$ silica gel plates on a plastic support (Merck) and revealed either by UV lamp $(254 \mathrm{~nm})$, iodine, ninhydrin $(10 \mathrm{mg} / \mathrm{mL}$ in EtOH) or with vanillin $\left(10 \mathrm{mg} / \mathrm{mL}_{\text {in }} \mathrm{H}_{2} \mathrm{SO}_{4}: \mathrm{EtOH}(4: 1)\right)$. Purifications were carried out using a Puriflash 600 (Interchim) with $30 \mu \mathrm{m}$ silica pre-packed columns. Mass spectrometry analyses were carried out on a CMS Expression apparatus (Advion) with electrospray ionization in positive and/or negative mode and equipped with a quadrupole analyzer. Highresolution mass spectrometry (HRMS) analyses were performed on a Synapt G2 HRMS QTOF mass spectrometer (Waters) equipped with an electrospray ionization (ESI) interface operating in the positive mode. HPLC analyses were carried out on a Waters Alliance e2695 HPLC system equipped with a C-18 column (Spherisorb ODS2 $5 \mu 4.6 \mathrm{~mm} \times 25 \mathrm{~cm}$, Waters) with the flow rate set at $1.50 \mathrm{~mL} / \mathrm{min}$ with the following gradient: $\mathrm{t}=0: 60 \% \mathrm{~A}, 40 \% \mathrm{~B} ; \mathrm{t}=$ 15 min: $100 \% \mathrm{~B}$; with $\mathrm{A}=\mathrm{H}_{2} \mathrm{O}$ with $0.05 \%$ TFA and $\mathrm{B}=\mathrm{CH}_{3} \mathrm{CN}$ with $0.05 \%$ TFA.

The use of molecules with azide functions requires precautions: organic azides present a risk of explosion and must therefore be handled with care, in particular by avoiding high temperatures, shocks and frictions and synthesized in small quantities. Especially, if the $\mathrm{C} / \mathrm{N}$ ratio is less than 1 , they should never be isolated or concentrated.

\subsection{2. (3-(azidomethyl)phenyl)(4-methoxyphenyl)iodonium tosylate (3)}

To a solution of 3-iodobenzylazide (1) $(200 \mathrm{mg}, 0.77 \mathrm{mmol})$ in $\mathrm{CHCl}_{3}(10 \mathrm{~mL})$ was added $\mathrm{m}$ chloroperbenzoic acid (193 mg, $0.86 \mathrm{mmol}, 1.1 \mathrm{eq})$. The solution was stirred at room temperature for 15 minutes. Then, $p$-toluenesulfonic acid monohydrate $(170 \mathrm{mg}, 0.88 \mathrm{mmol}$, $1.1 \mathrm{eq}$ ) and anisole ( $424 \mathrm{mg}, 3.88 \mathrm{mmol}, 5 \mathrm{eq}$ ) were added and the solution was stirred for 2 hours at $40^{\circ} \mathrm{C}$. The reaction mixture was concentrated in vacuo and the obtained residue was triturated in cold $\mathrm{Et}_{2} \mathrm{O}(20 \mathrm{~mL})$ until obtaining a white solid $(306 \mathrm{mg}, 74 \%) /{ }^{1} \mathrm{H}$ NMR (400 $\left.\mathrm{MHz}, \mathrm{CD}_{3} \mathrm{CN}\right): \delta$ 7.40-7.34 (m, 4H), $6.93(\mathrm{~d}, 1 \mathrm{H}, 7.6 \mathrm{~Hz}), 6.82-6.78(\mathrm{~m}, 3 \mathrm{H}), 6.47(\mathrm{~d}, 2 \mathrm{H}, 8$ $\mathrm{Hz}), 6.32(\mathrm{~d}, 2 \mathrm{H}, 8.8 \mathrm{~Hz}), 3.77\left(\mathrm{~s}, 2 \mathrm{H}, \mathrm{CH}_{2}\right), 3.17\left(\mathrm{~s}, 3 \mathrm{H}, \mathrm{CH}_{3}\right), 1.69\left(\mathrm{~s}, 3 \mathrm{H}, \mathrm{CH}_{3}\right) /{ }^{13} \mathrm{C} \mathrm{NMR}$ $\left(100 \mathrm{MHz}, \mathrm{CD}_{3} \mathrm{CN}\right): \delta 163.8,145.4,141.1,140.1,138.5,135.3,135.2,132.9,132.6,129.4$, 126.6, 118.5, 116.8, 104.7, 56.6, 54.0, $21.3 / \mathrm{t}_{\mathrm{R}}$ : $7.47 \mathrm{~min} / \mathrm{HRMS}$ : calculated for $\mathrm{C}_{14} \mathrm{H}_{13} \mathrm{~N}_{3} \mathrm{OI}$ $\mathrm{M}(+)$ and $\mathrm{C}_{35} \mathrm{H}_{33} \mathrm{~N}_{6} \mathrm{O}_{5} \mathrm{SI}_{2}{ }^{+} 2 \mathrm{M}+\mathrm{TsO}^{-}(+): 366.0103$ and 903.0315 , found : 366.0115 and 903.0327 .

\subsection{3. (4-methoxyphenyl)(4-(6-methyl-1,2,4,5-tetrazin-3-yl)phenyl)iodonium} trifluoroacetate (4) 
To a degassed solution of 3-(4-iodophenyl)-6-methyl-1,2,4,5-tetrazine (2) (0.167 g, 0.53 mmol) in dry acetonitrile $(15 \mathrm{~mL})$ was added dropwise a solution of trimethylsilyl acetate (216 mg, $1.59 \mathrm{mmol}, 3 \mathrm{eq})$ and SelectFluor ${ }^{\circledR}(277 \mathrm{mg}, 0.745 \mathrm{mmol}, 1.4 \mathrm{eq})$ in dry acetonitrile $(10 \mathrm{~mL})$. After $24 \mathrm{~h}$ stirring at room temperature under argon, potassium (4-methoxyphenyl) trifluoroborate $(130 \mathrm{mg}, 0.583 \mathrm{mmol}, 1.1 \mathrm{eq})$ and trimethylsilyl trifluoroacetate $(105 \mu \mathrm{L}$, $0.583 \mathrm{mmol}, 1.1 \mathrm{eq})$ were added and the resulting mixture was stirred under argon for 96 hours at room temperature. The reaction mixture was concentrated in vacuo and the obtained residue was triturated in cold $\mathrm{Et}_{2} \mathrm{O}(20 \mathrm{~mL})$ until obtaining a purple solid $(99,3 \mathrm{mg}, 36 \%)$. ${ }^{1} \mathrm{H}$ NMR (400 MHz, CD ${ }_{3} \mathrm{CN}$ ): $\delta 8.59$ (d, 2H, meta, $8.8 \mathrm{~Hz}$ ), $8.23(\mathrm{~d}, 2 \mathrm{H}$, ortho, $8.8 \mathrm{~Hz}), 8.06(\mathrm{~d}$, $2 \mathrm{H}$, ortho, $9.2 \mathrm{~Hz}$ ), 7.08 (d, $2 \mathrm{H}$, meta, $9.2 \mathrm{~Hz}$ ), 3.84 (s, $\left.3 \mathrm{H}, \mathrm{CH}_{3}\right), 3.05$ (s, $\left.3 \mathrm{H}, \mathrm{CH}_{3}\right) .{ }^{13} \mathrm{C} \mathrm{NMR}$ $\left(100 \mathrm{MHz}, \mathrm{CD}_{3} \mathrm{CN}\right): \delta 169.2,164.5,163.9,138.9,137.4,136.5,119.3,118.3,66.3,56.8$, 21.53, 15.6. ${ }^{19} \mathrm{~F}$ NMR (376 MHz, $\left.\mathrm{CD}_{3} \mathrm{CN}\right): \delta-80.0\left(\mathrm{CF}_{3} \mathrm{COO}^{-}, 80 \%\right),-154.7\left(\mathrm{BF}_{4}^{-}, 20 \%\right) / \mathrm{t}_{\mathrm{R}}$ : $7.82 \mathrm{~min} / \mathrm{HRMS}$ : calculated for $\mathrm{C}_{16} \mathrm{H}_{14} \mathrm{~N}_{4} \mathrm{OI} \mathrm{M}(+)$ : 405.0212 , found : 405.0219 .

\subsection{Radiochemistry}

\subsubsection{General}

$\mathrm{Na}\left[{ }^{125} \mathrm{I}\right] \mathrm{I}$ was obtained commercially from Perkin Elmer in $10^{-5} \mathrm{M} \mathrm{NaOH}$ solution with a volumic activity of $50 \mu \mathrm{Ci} / \mu \mathrm{L}(1.85 \mathrm{MBq} / \mu \mathrm{L}) .{ }^{211} \mathrm{At}$ was produced at the Arronax cyclotron facility using the ${ }^{209} \mathrm{Bi}(\alpha, 2 \mathrm{n})^{211} \mathrm{At}$ reaction and recovered from the irradiated target in chloroform using a dry-distillation protocol adapted from the procedure previously reported by Lindegren et al. ${ }^{28}$ Radio-HPLC analyses were performed using the system described in $\S 4.1 .1$ equipped with a Flow Star LB 513 radioactivity detector (BERTHOLD Technologies. Non-radioactive iodinated compounds were analyzed using this HPLC system and their retention times (given in Table S1) were used as references for identification of their radioiodinated and astatinated analogues.

\subsubsection{Radioiodination of aryliodonium salts $\mathbf{3}$ and $\mathbf{4}$}

A stock solution of $\mathrm{Na}\left[{ }^{125} \mathrm{I}\right] \mathrm{I}$ was prepared by diluting the commercial solution twelve times in de-ionized water. To a solution of diluted $\mathrm{Na}\left[{ }^{125} \mathrm{I}\right] \mathrm{I}(5 \mu \mathrm{L}, 770 \mathrm{kBq})$ was added the iodonium salt solution $(95 \mu \mathrm{L}, 5 \mathrm{mM})$ in $\mathrm{CH}_{3} \mathrm{CN}$. The solution was heated to the selected temperature for 30 minutes. After return to room temperature, an aliquot was withdrawn $(\approx$ $500 \mathrm{kBq})$ and diluted in a $3: 2 \mathrm{H}_{2} \mathrm{O} / \mathrm{CH}_{3} \mathrm{CN}$ solution $(100 \mu \mathrm{L})$ and analyzed by reverse-phase HPLC. Aromatic ${ }^{125} \mathrm{I}$-species were identified by comparison with the retention indexes of the non-radioactive iodinated compound.

\subsubsection{Astatination of aryliodonium salts $\mathbf{3}$ and $\mathbf{4}$}

A stock solution of $\mathrm{Na}\left[{ }^{211} \mathrm{At}\right]$ At was prepared as follow: the chloroform ${ }^{211} \mathrm{At}$ solution was evaporated to dryness under a gentle stream of nitrogen and redissolved in an appropriate volume of a $10 \mathrm{mg} / \mathrm{mL}$ sodium sulfite aqueous solution to obtain a volumic activity of about $400 \mathrm{kBq} / \mu \mathrm{L}$. To a solution of sodium astatide $(5 \mu \mathrm{L}, \approx 2 \mathrm{MBq})$ was added a solution of iodonium salt $(95 \mu \mathrm{L}, 5 \mathrm{mM})$ in the selected solvent $\left(\mathrm{CH}_{3} \mathrm{CN}\right.$ or $\left.\mathrm{MeOH}\right)$. The solution was heated to the selected temperature for 30 minutes. After return to room temperature, an aliquot was withdrawn $(\approx 500 \mathrm{kBq})$ and diluted in a $3: 2 \mathrm{H}_{2} \mathrm{O} / \mathrm{CH}_{3} \mathrm{CN}$ solution $(100 \mu \mathrm{L})$ and analyzed by reverse-phase HPLC. Aromatic ${ }^{211}$ At-species were identified by comparison of the retention indexes of the non-radioactive iodinated compounds with an offset of $\approx 0.1 \mathrm{~min}$.

\subsubsection{Purification of radioiodinated and astatinated benzylazide compounds $\mathbf{1 a / 1 b}$}


After labeling, the solution was evaporated to dryness and the radioiodinated (1a) or astatinated (1b) compound was extracted with 2 x $50 \mu \mathrm{L}$ of $\mathrm{Et}_{2} \mathrm{O}$ (extraction efficiency: 80$90 \%$ ). $\mathrm{Et}_{2} \mathrm{O}$ was then evaporated at $40^{\circ} \mathrm{C}$ under a gentle stream of nitrogen. After all solvent was removed, additional drying for about five minutes allowed the complete removal of anisole derivatives $\mathbf{0 a} / \mathbf{0 b}$. The radiolabeled compound was then taken up in $\mathrm{MeOH}$ and the purity was measured with an aliquot diluted in a $3: 2 \mathrm{H}_{2} \mathrm{O} / \mathrm{CH}_{3} \mathrm{CN}$ solution $(100 \mu \mathrm{L}, \approx 600$ $\mathrm{kBq}$ ) and analyzed by reverse-phase HPLC.

\subsubsection{Purification of radioiodinated and astatinated aryltetrazine compounds $\mathbf{2 a / 2 b}$}

After labeling, the solution was evaporated to dryness and the radioiodinated (2a) or astatinated (2b) compound was recovered by filtration on a disposable Sep-Pak Vac 3cc (500 mg) silica cartridges (Waters) on which the iodonium salt was retained when using AcOEt $(600 \mu \mathrm{L})$ as eluent. 2a and $\mathbf{2 b}$ were obtained as mixtures with anisole derivatives $\mathbf{0 a}$ and $\mathbf{0 b}$, respectively. AcOEt was then evaporated at $40^{\circ} \mathrm{C}$ under a gentle stream of nitrogen. After all solvent was removed, additional drying for about five minutes allowed the complete removal of anisole derivatives $\mathbf{0 a} / \mathbf{0 b}$. The radiolabeled compound was taken up in $\mathrm{MeOH}$ and the purity was measured with an aliquot diluted in a $3: 2 \mathrm{H}_{2} \mathrm{O} / \mathrm{CH}_{3} \mathrm{CN}$ mixture $(100 \mu \mathrm{L}$, $\approx$ $600 \mathrm{kBq}$ ) and analyzed by reverse-phase HPLC.

\subsection{Clickable peptide radiolabeling}

\subsubsection{Radiolabeling of clickable peptides 15, 16, 17 with $\mathbf{1 a} / \mathbf{1 b}$ or $\mathbf{2 a / 2 b}$ (SPAAC and IEDDA)}

To a solution of clickable peptide $\mathbf{1 5}, 16$ or $17(90 \mu \mathrm{L}, 200 \mu \mathrm{M})$ in $\mathrm{PBS} / \mathrm{MeOH}(99: 1)$ was added a solution of iodinated (1a or $\mathbf{2 a}$ ) or astatinated (1) or $\mathbf{2 b})$ compound (1.5 MBq, $10 \mu \mathrm{L})$ in $\mathrm{MeOH}$ and the solution was stirred at room temperature. An aliquot diluted in a $3: 2 \mathrm{H}_{2} \mathrm{O}$ / $\mathrm{CH}_{3} \mathrm{CN}$ solution $(100 \mu \mathrm{L}, 600 \mathrm{kBq})$ was analyzed at the times chosen by reverse-phase HPLC. Products were identified by comparison of the retention indexes of the non-radioactive iodinated clickable peptides.

\subsubsection{Radiolabeling of clickable peptide $\mathbf{1 4}$ with $\mathbf{1 a} / \mathbf{1 b}(\boldsymbol{C u} \boldsymbol{A} \boldsymbol{A C})$}

To a solution of clickable peptide $14(9 \mu \mathrm{L}, 2.3 \mathrm{mM})$ in $\mathrm{PBS} / \mathrm{MeOH}(99: 1)$ was added $58.5 \mu \mathrm{L}$ of de-ionized water, aqueous sodium ascorbate $(7.5 \mu \mathrm{L}, 15 \mathrm{mM})$, aqueous tris(3hydroxypropyltriazolylmethyl)amine ligand (THPTA) $(5 \mu \mathrm{L}, 25 \mathrm{mM})$, aqueous $\mathrm{Cu}(\mathrm{OAc})_{2}(10$ $\mu \mathrm{L}, 20 \mathrm{mM}$ ) and a solution of iodinated (1a) or astatinated (1b) compound (1.5 MBq, $10 \mu \mathrm{L})$ in $\mathrm{MeOH}$. The solution was stirred at room temperature and an aliquot diluted in a $3: 2 \mathrm{H}_{2} \mathrm{O}$ / $\mathrm{CH}_{3} \mathrm{CN}$ solution $(100 \mu \mathrm{L}, 600 \mathrm{kBq})$ was analyzed at the times chosen by reverse-phase HPLC Products were identified by comparison of the retention indexes of the non-radioactive iodinated clickable peptides.

\subsection{E7.4- IgG modification with DIBAC}

To a solution of 9E7.4-IgG $\left(320 \mu \mathrm{L}, 4.5 \mathrm{mg} / \mathrm{mL}\right.$, produced as reported previously $\left.{ }^{25}\right)$ in borate buffer (0.3 M, pH 8.6) was added a solution of DBCO-NHS Ester (click Chemistry Tools) (15 $\mu \mathrm{L}, 10 \mathrm{mM}, 15 \mathrm{eq})$ in DMSO. After $60 \mathrm{~min}$ of incubation at $23^{\circ} \mathrm{C}$, excess of DBCO-NHS Ester was removed by filtration on centrifugal filters (Amicon ${ }^{\circledR}$ Ultra-2mL-30K) with PBS and the obtained 9E7.4-DIBAC was stored $(2.3 \mathrm{mg} / \mathrm{mL})$ at $4{ }^{\circ} \mathrm{C}$.

To determine the average number of reactive DIBAC groups per antibody, a solution of Cy5azide ( 0.1 to 2 eq.) in methanol $(2 \mu \mathrm{L})$ was added to a solution of 9E7.4-DIBAC (16.4 pmol) in PBS $(98 \mu \mathrm{L})$. The reaction mixture was stirred at $23^{\circ} \mathrm{C}$ overnight and an aliquot was deposited on a ITLC-SG strip which was eluted with $\mathrm{MeOH}$. The fractions of Cy5-Azide 
bound to the IgG (bottom of ITLC-SG) and unbound (top of ITLC-SG) were determined by integrating the area of each spot using a BioRad Chemidoc ${ }^{\mathrm{TM}}$ Imaging system in fluorescence detection mode. A ratio of $0.21 \pm 0.05 \mathrm{DIBAC} / \mathrm{IgG}$ was measured.

\subsection{E7.4-DIBAC radiolabeling with $\mathbf{1 b}$}

To $\mathbf{1 b}$ in $\mathrm{MeOH}(10 \mu \mathrm{L})$, prepared as described above, was added 9E7.4-DIBAC $(60 \mu \mathrm{L}$ of a $2.3 \mathrm{mg} / \mathrm{mL}$ solution in PBS). After up to $40 \mathrm{~min}$ of incubation at $23^{\circ} \mathrm{C}$, the conjugation yield was assessed by elution of an aliquot deposited on an ITLC-SG strip (methanol as eluent), and integration of the plate using a Cyclone phosphorimager scanner (Perkin Elmer). Purification was performed by gel filtration on a Sephadex G-25 resin loaded column (PD-10, GE healthcare) using PBS as eluent, affording the purified radiolabeled antibody with a $>99 \%$ radiochemical purity as assessed by ITLC-SG.

\subsection{Immunoreactivity assay}

The immunoreactive fraction of 1b-DIBAC-9E7.4 was determined using magnetic beads (Pierce, Thermo Scientific) labeled with a 40 amino acids peptide recognized by the 9E7.4 antibody according to the supplier's protocol. One picomole of radiolabeled 9E7.4 was incubated for $15 \mathrm{~min}$ at room temperature with $20 \mu \mathrm{L}$ of coated magnetic beads $(10 \mathrm{mg} / \mathrm{mL})$. Using a magnetic rack, supernatants containing non-reactive antibodies and magnetic beads were collected separately and the radioactivity in each fraction was measured in a gamma counter. Nonspecific binding was measured with the same protocol except that magnetic beads were coated with bovine serum albumin (BSA), and was below 5\%.

\section{$\underline{\text { Acknowledgement }}$}

This research was supported in part by grants from the French National Agency for Research, called "Investissements d'Avenir" IRON Labex no. ANR-11-LABX-0018-01 and ArronaxPlus Equipex no. ANR-11-EQPX-0004, and by grant INCa-DGOS-Inserm_12558. Sébastien Gouard is thanked for 9E7.4 production and immunoreactivity assays. Cyrille Alliot is thanked for providing the purified ${ }^{211}$ At sources. The Radioactivity Technical Platform (SFR Santé François Bonamy) is thanked for the technical support.

\section{$\underline{\text { References }}$}

1. Adam MJ, Wilbur DS. Radiohalogens for imaging and therapy. Chem Soc Rev. 2005;34(2):153-163. doi:10.1039/b313872k

2. Guérard F, Gestin J-F, Brechbiel MW. Production of [211At]-Astatinated Radiopharmaceuticals and Applications in Targeted $\alpha$-Particle Therapy. Cancer Biother Radiopharm. 2013;28(1):1-20. doi:10.1089/cbr.2012.1292

3. Meyer G-J. Astatine. J Label Compd Radiopharm. 2018;61(3):154-164. doi:10.1002/jlcr.3573

4. Garg PK, Alston KL, Zalutsky MR. Catabolism of radioiodinated murine monoclonal antibody $\mathrm{F}\left(\mathrm{ab}^{\prime}\right) 2$ fragment labeled using $\mathrm{N}$-succinimidyl 3-iodobenzoate and Iodogen methods. Bioconjugate Chem. 1995;6(4):493-501. doi:10.1021/bc00034a020

5. Kim EJ, Kim BS, Choi DB, Chi S-G, Choi TH. Enhanced tumor retention of radioiodinated anti-epidermal growth factor receptor antibody using novel bifunctional iodination linker for radioimmunotherapy. Oncology Reports. 2016;35(6):3159-3168. doi:10.3892/or.2016.4706 
6. Visser GWM, Diemer EL, Kaspersen FM. The preparation and stability of astatotyrosine and astato-iodotyrosine. Int $J$ Appl Radiat Isot. 1979;30(12):749-752. doi:10.1016/0020708X(79)90154-6

7. Zalutsky MR, Garg PK, Friedman HS, Bigner DD. Labeling monoclonal antibodies and $\mathrm{F}\left(\mathrm{ab}^{\prime}\right) 2$ fragments with the alpha-particle-emitting nuclide astatine-211: preservation of immunoreactivity and in vivo localizing capacity. Proc Natl Acad Sci USA. 1989;86(18):7149-7153. doi:10.1073/pnas.86.18.7149

8. Choi J, Vaidyanathan G, Koumarianou E, Kang CM, Zalutsky MR. Astatine-211 labeled antiHER2 5F7 single domain antibody fragment conjugates: radiolabeling and preliminary evaluation. Nucl Bed Biol. 2018;56(Supplement C):10-20. doi:10.1016/j.nucmedbio.2017.09.003

9. Aneheim E, Gustafsson A, Albertsson P, et al. Synthesis and Evaluation of Astatinated N-[2(Maleimido)ethyl]-3-(trimethylstannyl)benzamide Immunoconjugates. Bioconjugate Chem. 2016;27(3):688-697. doi:10.1021/acs.bioconjchem.5b00664

10. Guérard F, Navarro L, Lee Y-S, et al. Bifunctional aryliodonium salts for highly efficient radioiodination and astatination of antibodies. Bioorg Med Chem. 2017;25(21):5975-5980. doi:10.1016/j.bmc.2017.09.022

11. Lang K, Chin JW. Bioorthogonal Reactions for Labeling Proteins. ACS Chem Biol. 2014;9(1):16-20. doi:10.1021/cb4009292

12. Meyer J-P, Adumeau P, Lewis JS, Zeglis BM. Click Chemistry and Radiochemistry: The First 10 Years. Bioconjugate Chem. October 2016. doi:10.1021/acs.bioconjchem.6b00561

13. Jeon J, Kang JA, Shim HE, et al. Efficient method for iodine radioisotope labeling of cyclooctyne-containing molecules using strain-promoted copper-free click reaction. Bioorg Med Chem. 2015;23(13):3303-3308. doi:10.1016/j.bmc.2015.04.045

14. Choi MH, Shim HE, Nam YR, et al. Synthesis and evaluation of an 125I-labeled azide prosthetic group for efficient and bioorthogonal radiolabeling of cyclooctyne-group containing molecules using copper-free click reaction. Bioorg Med Chem Letters. 2016;26(3):875-878. doi:10.1016/j.bmcl.2015.12.073

15. Choi MH, Shim HE, Yun S-J, et al. Highly efficient method for 125I-radiolabeling of biomolecules using inverse-electron-demand Diels-Alder reaction. Bioorg Med Chem. 2016;24(11):2589-2594. doi:10.1016/j.bmc.2016.04.029

16. Albu SA, Al-Karmi SA, Vito A, et al. 125I-Tetrazines and Inverse-Electron-Demand DielsAlder Chemistry: A Convenient Radioiodination Strategy for Biomolecule Labeling, Screening, and Biodistribution Studies. Bioconjugate Chem. 2016;27(1):207-216. doi:10.1021/acs.bioconjchem.5b00609

17. Pozzi OR, Zalutsky MR. Radiopharmaceutical chemistry of targeted radiotherapeutics, Part 2: radiolytic effects of 211At alpha-particles influence N-succinimidyl 3-211AT-astatobenzoate synthesis. J Nucl Med. 2005;46(8):1393-1400.

18. Guérard F, Lee Y-S, Baidoo K, Gestin J-F, Brechbiel MW. Unexpected Behavior of the Heaviest Halogen Astatine in the Nucleophilic Substitution of Aryliodonium Salts. Chem Eur J. 2016;22(35):12332-12339. doi:10.1002/chem.201600922

19. Qin L, Hu B, Neumann KD, et al. A Mild and General One-Pot Synthesis of Densely Functionalized Diaryliodonium Salts. Eur J Org Chem. 2015;2015(27):5919-5924. doi:10.1002/ejoc.201500986

20. Talanov VS, Garmestani K, Regino CAS, et al. Preparation and in vivo evaluation of a novel stabilized linker for 211At labeling of protein. Nucl Med Biol. 2006;33(4):469-480. doi:10.1016/j.nucmedbio.2006.03.001

21. Rajerison H, Faye D, Roumesy A, et al. Ionic liquid supported organotin reagents to prepare molecular imaging and therapy agents. Org Biomol Chem. 2016;14(6):2121-2126. doi:10.1039/C5OB02459E 
22. Otto S, Engberts JBFN. Hydrophobic interactions and chemical reactivity. Org Biomol Chem. 2003;1(16):2809-2820. doi:10.1039/B305672D

23. Selvaraj R, Giglio B, Liu S, et al. Improved Metabolic Stability for 18F PET Probes Rapidly Constructed via Tetrazine trans-Cyclooctene Ligation. Bioconjugate Chem. 2015;26(3):435442. doi:10.1021/acs.bioconjchem.5b00089

24. Li S, Cai H, He J, et al. Extent of the Oxidative Side Reactions to Peptides and Proteins During the CuAAC Reaction. Bioconjugate Chem. 2016;27(10):2315-2322. doi:10.1021/acs.bioconjchem.6b00267

25. Fichou N, Gouard S, Maurel C, et al. Single-dose anti-CD138 radioimmunotherapy: bismuth213 is more efficient than lutetium-177 for treatment of multiple myeloma in a preclinical model. Front Med. 2015:76. doi:10.3389/fmed.2015.00076

26. Chun J-H, Pike VW. Single-Step Radiosynthesis of "18F-Labeled Click Synthons" from Azide-Functionalized Diaryliodonium Salts. Eur J Org Chem. 2012;2012(24):4541-4547. doi:10.1002/ejoc.201200695

27. Yang J, Karver MR, Li W, Sahu S, Devaraj NK. Metal-Catalyzed One-Pot Synthesis of Tetrazines Directly from Aliphatic Nitriles and Hydrazine. Angew Chem Int Ed. 2012;51(21):5222-5225. doi:10.1002/anie.201201117

28. Lindegren S, Bäck T, Jensen HJ. Dry-distillation of astatine-211 from irradiated bismuth targets: a time-saving procedure with high recovery yields. Appl Radiat Isot. 2001;55(2):157160. doi: 10.1016/S0969-8043(01)00044-6 


\section{Electronic Supplementary Information}

\section{Prosthetic groups for radioiodination and astatination of peptides and} proteins: a comparative study of five potential bioorthogonal labeling strategies

Laurent Navarro, Marion Berdal, Michel Chérel, Frédéric Pecorari, Jean-François Gestin*, François Guérard*

\section{1) SYNTHESIS}

\section{1) Model peptide}

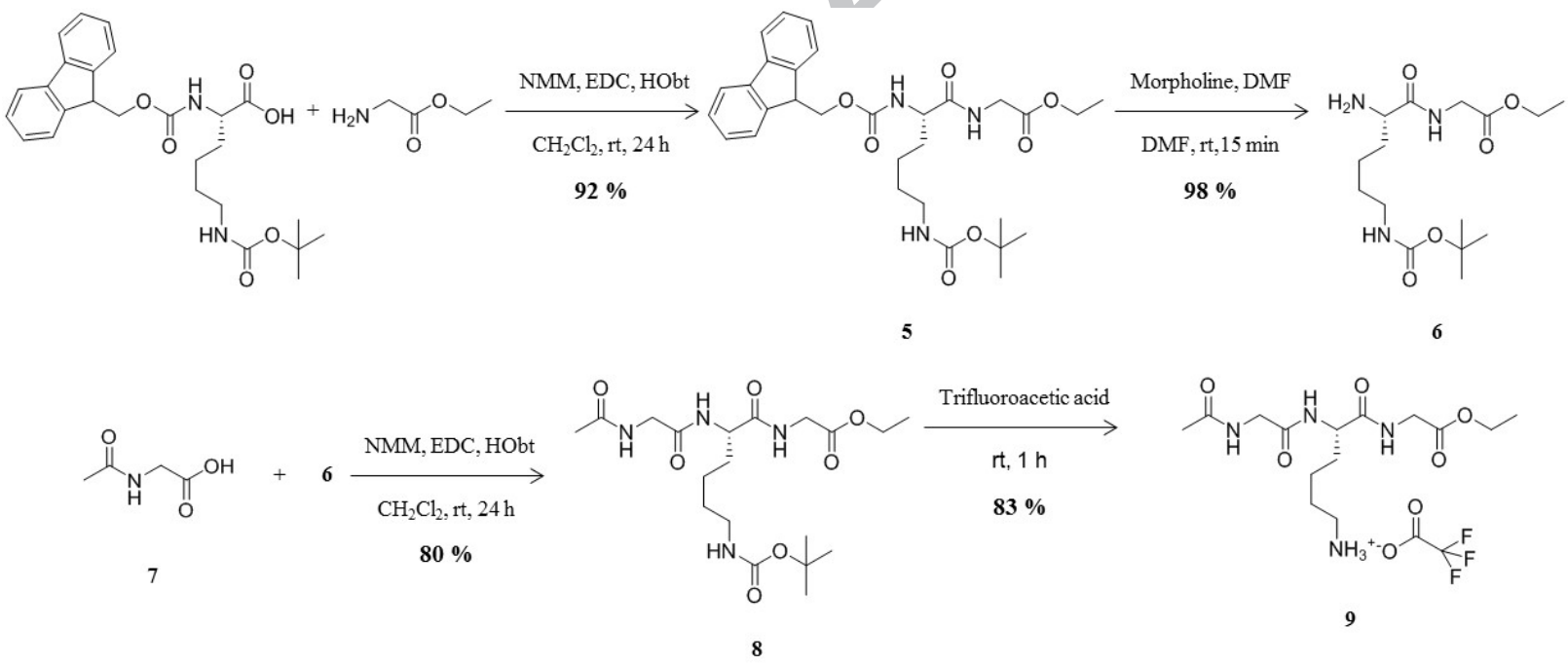

$\boldsymbol{N}_{\boldsymbol{\alpha}}$-Fmoc- $\boldsymbol{N}_{\varepsilon}$-Boc-lysylglycine ethyl ester (5). To a solution $N \alpha$-Fmoc- $N \varepsilon$-Boc-lysine $(9.99 \mathrm{~g}, 20.9$ mmol) in anhydrous $\mathrm{CH}_{2} \mathrm{Cl}_{2}(150 \mathrm{~mL})$ was added in the following order: $N$-methylmorpholine (5.80 $\mathrm{mL}, 52.3 \mathrm{mmol}, 2.5 \mathrm{eq}$ ), $N$-(3-dimethylaminopropyl)- $N N^{\prime}$-ethylcarbodiimide hydrochloride (EDC) (6.13 g, $31.4 \mathrm{mmol}, 1.5 \mathrm{eq})$, HObt (4.37 g, $31.4 \mathrm{mmol}, 1.5 \mathrm{eq})$ and ethylglycinate hydrochloride (3.54 g, $25.1 \mathrm{mmol}, 1.2 \mathrm{eq})$. The solution was stirred for 24 hours under argon at room temperature. The reaction mixture was then washed with a $0.2 \mathrm{M}$ aqueous $\mathrm{HCl}$ solution $(75 \mathrm{~mL})$, a $1 \mathrm{M}$ aqueous $\mathrm{Na}_{2} \mathrm{CO}_{3}$ solution $(50 \mathrm{~mL})$ and $\mathrm{H}_{2} \mathrm{O}(2 \times 75 \mathrm{~mL})$. The organic layer was dried over $\mathrm{MgSO}_{4}$ and concentrated under reduced pressure. The crude product was purified on silica gel $\left(\mathrm{CHCl}_{3} / \mathrm{MeOH}\right.$ as eluent) to give the desired compound as white solid (10.6 g, $92 \%$ ). ${ }^{1} \mathrm{H}$ NMR (400 MHz, DMSO- $\left.d_{6}\right): \delta$ 8.32 (s, 1H, NH), 7.89 (d, 2H, 7.6 Hz), 7.75-7.72 (m, 2H), 7.51 (s, 1H, NH), 7.42 (t, 2H, 7.2 Hz), 7.33 
(t, 2H, 7.2 Hz), 6.78 (s, 1H, NH), 4.31-4.19 (m, 3H), 4.07 (q, 2H, 7.2 Hz), 4.02-3.98 (m, 1H, CH), 3.90-3.74 (m, 2H, CH $), 2.89(\mathrm{~m}, 2 \mathrm{H}), 1.68-1.51\left(\mathrm{~m}, 2 \mathrm{H}, \mathrm{CH}_{2}\right), 1.46-1.22(\mathrm{~m}, 13 \mathrm{H}), 1.18\left(\mathrm{t}, 3 \mathrm{H}, \mathrm{CH}_{3}\right) /$ ${ }^{13} \mathrm{C}$ NMR (100 MHz, DMSO- $\left.d_{6}\right): \delta 172.6,169.7,156.0,155.6,143.8,140.8,139.5,137.4,128.9$, $127.6,127.1,125.4,121.4,120.1,77.4,65.7,60.4,54.4,46.7,40.6,31.7,29.4,28.3,22.8,14.0$ ESI (+): $\mathrm{M}+\mathrm{H}(554.4) / \mathrm{M}+\mathrm{Na}(576.4) / 2 \mathrm{M}+\mathrm{Na}(1129.8) / \mathrm{Rf:} 0.33\left(\mathrm{CHCl}_{3} / \mathrm{MeOH}: 95 / 5\right)$.

$N_{\varepsilon}$-Boc-lysylglycine ethyl ester (6). To a solution of $\mathrm{N} \alpha$-Fmoc-N $\varepsilon$-Boc-lysylglycine ethyl ester (5) (3 g, $5.4 \mathrm{mmol})$ in dry DMF $(15 \mathrm{~mL})$ was added morpholine $(15 \mathrm{~mL})$. The mixture was stirred for 5 minutes and rapidly concentrated under reduced pressure. The crude product was purified on silica gel $\left(\mathrm{CHCl}_{3} / \mathrm{MeOH}\right)$ to give the desired compound as a colorless oil $(1.75 \mathrm{~g}, 98 \%) .{ }^{1} \mathrm{H}$ NMR $(400 \mathrm{MHz}$, DMSO- $\left.d_{6}\right): \delta 8.24(\mathrm{~s}, 1 \mathrm{H}, \mathrm{NH}), 6.75(\mathrm{~s}, 1 \mathrm{H}, \mathrm{NH}), 4.08(\mathrm{q}, 2 \mathrm{H}, 7.2 \mathrm{~Hz}), 3.83-3.81\left(\mathrm{~m}, 2 \mathrm{H}, \mathrm{CH}_{2}\right), 3.15-$ $3.12(\mathrm{~m}, 1 \mathrm{H}, \mathrm{CH}), 2.90-2.85\left(\mathrm{~m}, 2 \mathrm{H}, \mathrm{CH}_{2}\right), 1.90-1.68(\mathrm{~m}, 1 \mathrm{H}), 1.59-1.51(\mathrm{~m}, 1 \mathrm{H}), 1.42-1.24(\mathrm{~m}, 13 \mathrm{H})$, $1.18\left(\mathrm{~m}, 3 \mathrm{H}, \mathrm{CH}_{3}, 6.8 \mathrm{~Hz}\right) /{ }^{13} \mathrm{C} \mathrm{NMR}\left(100 \mathrm{MHz}, \mathrm{DMSO}-d_{6}\right): \delta 175.8,169.9,155.5,77.3,60.3,54.9$, 54.5, 40.5, 34.8, 29.4, 28.2, 22.4, 14.0 / ESI (+): $\mathrm{M}+\mathrm{H}(332.3) / \mathrm{M}+\mathrm{Na}(354.3) / 2 \mathrm{M}+\mathrm{H}(663.6) /$ $2 \mathrm{M}+\mathrm{Na}(685.5)$ / Rf: $0.36\left(\mathrm{CHCl}_{3} / \mathrm{MeOH}: 90 / 10\right)$.

Acetylglycine (7). To a solution of glycine $(5 \mathrm{~g}, 66 \mathrm{mmol})$ in $\mathrm{H}_{2} \mathrm{O}(20 \mathrm{~mL})$ was added in one portion and under stirring acetic anhydride $(16.6 \mathrm{~mL}, 132 \mathrm{mmol}, 2 \mathrm{eq})$. The solution was stirred for 30 minutes (exothermic reaction). When the solution was returned to room temperature (the first crystals appear) the reaction mixture was placed in the refrigerator overnight to promote crystallization. The crystals were collected by filtration, washed with ice-cold water and dried in an oven at $100{ }^{\circ} \mathrm{C}$ overnight (5.31g, $70 \%$ ). ${ }^{1} \mathrm{H}$ NMR (400 MHz, DMSO- $\left.d_{6}\right): \delta 12.50(\mathrm{~s}, 1 \mathrm{H}, \mathrm{OH}), 8.17(\mathrm{~s}, 1 \mathrm{H}, \mathrm{NH}), 3.70$ (d, $\left.2 \mathrm{H}, \mathrm{CH}_{2}, 5.6 \mathrm{~Hz}\right), 1.84$ (s, 3H, $\left.\mathrm{CH}_{3}\right) /{ }^{13} \mathrm{C}$ NMR (100 MHz, DMSO- $\left.d_{6}\right): \delta 171.4,169.6,40.6,22.3$ / ESI (-): M-H (116.1).

$N_{\alpha}$-(acetylglycyl)- $N_{\varepsilon}$-Boc-lysylglycine ethyl ester (8). To a solution of acetylglycine (7) (0.528 g, 4.5 mmol, 1 eq) in $\mathrm{CH}_{2} \mathrm{Cl}_{2}(75 \mathrm{~mL})$ was added in the following order: $N \varepsilon$-Boc-lysylglycine ethyl ester (6) $(1.79 \mathrm{~g}, 5.4 \mathrm{mmol}, 1.2 \mathrm{eq}), N$-methylmorpholine (1.30 ml, $11.7 \mathrm{mmol}, 2.5 \mathrm{eq})$, EDC (1.33 g, 6.8 mmol, $1.5 \mathrm{eq})$ and finally HObt $(0.943 \mathrm{~g}, 6.8 \mathrm{mmol}, 1.5 \mathrm{eq})$. The mixture was stirred for 24 hours under argon upon which the product precipitated. The obtained precipitate was collected by filtration, washed with cold $\mathrm{CH}_{2} \mathrm{Cl}_{2}$ and dried in vacuo. (1.52 g, $\left.80 \%\right)$. ${ }^{1} \mathrm{H}$ NMR (400 MHz, DMSO- $\left.d_{6}\right): \delta 8.36$ (s, 1H, NH), 8.07 (s, 1H, NH), $7.99(\mathrm{~d}, 1 \mathrm{H}, \mathrm{NH}), 6.76(\mathrm{~s}, 1 \mathrm{H}, \mathrm{NH}), 4.27-4.22(\mathrm{~m}, 1 \mathrm{H}), 4.07$ (q, 2H, 7.2 $\mathrm{Hz}), 3.81-3.78\left(\mathrm{~m}, 2 \mathrm{H}, \mathrm{CH}_{2}\right), 3.71(\mathrm{~d}, 2 \mathrm{H}, 5.6 \mathrm{~Hz}), 2.89-2.84\left(\mathrm{~m}, 2 \mathrm{H}, \mathrm{CH}_{2}\right), 1.84\left(\mathrm{~s}, 3 \mathrm{H}, \mathrm{CH}_{3}\right), 1.69-$ $1.60(\mathrm{~m}, 1 \mathrm{H}), 1.54-1.45(\mathrm{~m}, 1 \mathrm{H}), 1.43-1.23(\mathrm{~m}, 13 \mathrm{H}), 1.18\left(\mathrm{t}, 3 \mathrm{H}, \mathrm{CH}_{3}, 6.8 \mathrm{~Hz}\right) /{ }^{13} \mathrm{C} \mathrm{NMR}(100 \mathrm{MHz}$, DMSO- $\left.d_{6}\right): \delta 172.1,169.6,169.5,168.8,155.5,77.4,60.4,52.2,42.0,40.7,31.8,29.3,28.3,22.6$, 22.5, 14.0 / $\mathrm{ESI}(+): \mathrm{M}+\mathrm{H}(431.4)$ / $\mathrm{M}+\mathrm{Na}(459.4)$ / 2M+H (861.9) / Rf: 0.48 ( $\left.\mathrm{CHCl}_{3} / \mathrm{MeOH}: 9: 1\right)$

$N_{\alpha}$-(acetylglycyl)-lysylglycine ethyl ester trifluoroacetate salt (9). A solution of ethyl $N \alpha-$ (acetylglycyl)-Ne-Boc-lysylglycine ethyl ester (8) $(1.47 \mathrm{~g}, 3.42 \mathrm{mmol})$ in trifluoroacetic acid $(30 \mathrm{~mL})$ 
was stirred for 1 hour. The reaction mixture was then concentrated under reduced pressure and the yellow oil obtained was triturated in cold $\mathrm{Et}_{2} \mathrm{O}$ until formation of a white solid. $\mathrm{Et}_{2} \mathrm{O}$ was removed by filtration and the white solid was dried under vacuum overnight $(1.26 \mathrm{~g}, 83 \%) .{ }^{1} \mathrm{H}$ NMR $(400 \mathrm{MHz}$, DMSO- $\left.d_{6}\right): \delta 8.38(\mathrm{~s}, 1 \mathrm{H}, \mathrm{NH}), 8.11(\mathrm{~s}, 1 \mathrm{H}, \mathrm{NH}), 8.03(\mathrm{~s}, 1 \mathrm{H}, \mathrm{NH}), 7.67\left(\mathrm{~s}, 3 \mathrm{H}, \mathrm{NH}_{3}\right), 4.31-4.25(\mathrm{~m}$, $1 \mathrm{H}), 4.08$ (q, 2H, $7.2 \mathrm{~Hz}), 3.82-3.80\left(\mathrm{~m}, 2 \mathrm{H}, \mathrm{CH}_{2}\right), 3.72-3.69\left(\mathrm{~m}, 2 \mathrm{H}, \mathrm{CH}_{2}\right), 2.80-2.71\left(\mathrm{~m}, 2 \mathrm{H}, \mathrm{CH}_{2}\right)$, $1.85\left(\mathrm{~s}, 3 \mathrm{H}, \mathrm{CH}_{3}\right), 1.75-1.63\left(\mathrm{~m}, 1 \mathrm{H}, \mathrm{CH}_{2}\right), 1.57-1.46(\mathrm{~m}, 3 \mathrm{H}), 1.38-1.26\left(\mathrm{~m}, 2 \mathrm{H}, \mathrm{CH}_{2}\right), 1.18(\mathrm{t}, 3 \mathrm{H}$, $\left.\mathrm{CH}_{3}, 6.8 \mathrm{~Hz}\right) /{ }^{13} \mathrm{C}$ NMR $\left(100 \mathrm{MHz}, \mathrm{DMSO}-d_{6}\right): \delta 172.0,169.7,169.6,167.0,60.5,52.0,42.3,42.0$, 40.7, 31.3, 26.5, 22.4, 22.0, 14.1 / ESI (+): M (331.2) / Rf : $0.19\left(\mathrm{CHCl}_{3} / \mathrm{MeOH}: 4: 1\right)$.

\section{2) Clickable linkers}

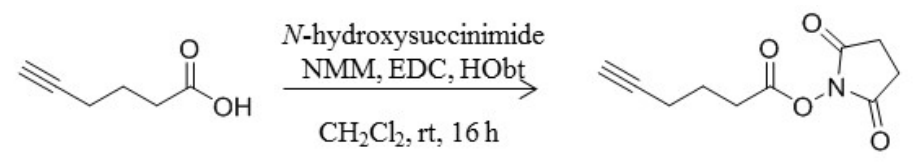

$70 \%$

10

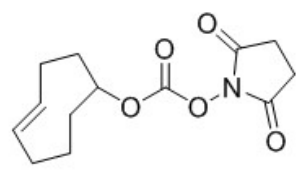

and<smiles>O=C(CCC(=O)N1Cc2ccccc2C#Cc2ccccc21)ON1C(=O)CCC1=O</smiles>

11

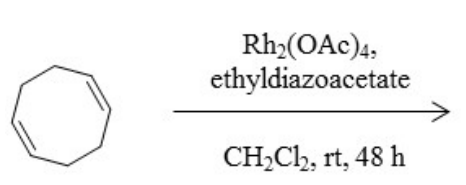

$48 \%$
12

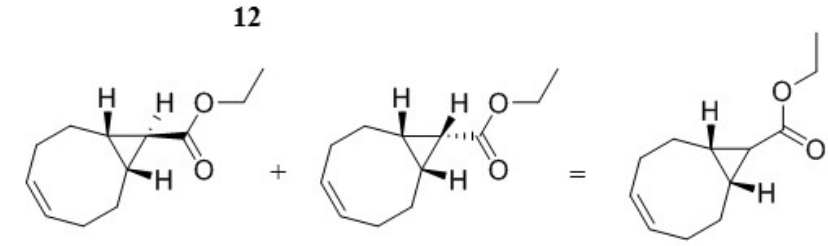

endo 2:1 exo

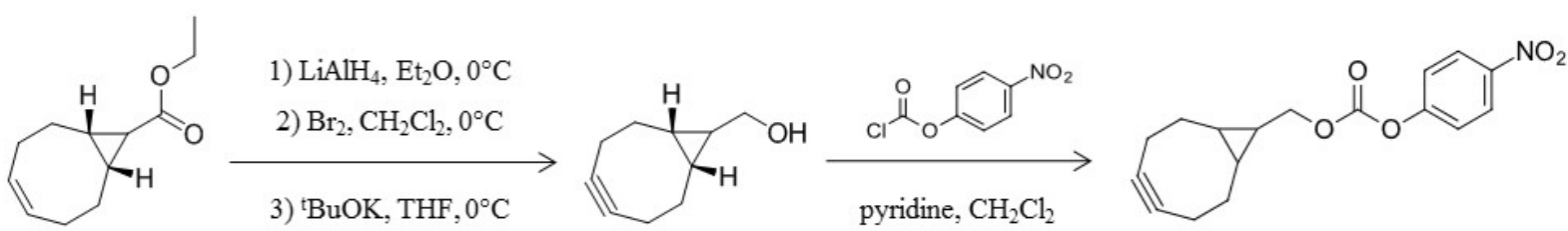

4) $80^{\circ} \mathrm{C}, 2 \mathrm{~h}$

$51 \%$

13

$42 \%$

$N$-succinimidyl 5-hexynoate (10). To a solution of 5-hexynoic acid $(500 \mu \mathrm{L}, 4.3 \mathrm{mmol})$ in anhydrous $\mathrm{CH}_{2} \mathrm{Cl}_{2}(15 \mathrm{~mL})$ were added in the following order: NMM $(720 \mu \mathrm{L}, 6.5 \mathrm{mmol}, 1.5 \mathrm{eq})$, EDC $(1.27 \mathrm{~g}$, $6.5 \mathrm{mmol}, 1.5 \mathrm{eq})$ and $N$-hydroxysuccinimide $(0.77 \mathrm{~g}, 6.5 \mathrm{mmol}, 1.5 \mathrm{eq})$. The solution was stirred overnight at room temperature under argon. The reaction mixture was washed with $0.2 \mathrm{~N}$ aqueous $\mathrm{HCl}$ $(10 \mathrm{~mL}), \mathrm{H}_{2} \mathrm{O}(10 \mathrm{~mL})$ and brine $(10 \mathrm{~mL})$. The organic layer was dried over $\mathrm{MgSO}_{4}$ and concentrated under reduced pressure. The crude product was purified on silica gel $\left(\mathrm{CHCl}_{3} / \mathrm{EtOAc}\right)$ to give the desired compound as white solid (640 mg, $70 \%$ ). ${ }^{1} \mathrm{H}$ NMR (400 MHz, $\left.\mathrm{CDCl}_{3}\right)$ : $\delta 2.84\left(\mathrm{~s}, 4 \mathrm{H}, 2 \mathrm{CH}_{2}\right.$ ), 2.78 (t, 2H, $\left.\mathrm{CH}_{2}, 7.6 \mathrm{~Hz}\right), 2.35$ (dt, 2H, $\left.\mathrm{CH}_{2}, 6.8 \mathrm{~Hz}\right), 2.01$ (t, 1H, CH, $\left.2.8 \mathrm{~Hz}\right), 1.97$ (q, 2H, $\mathrm{CH}_{2}, 7.2$ 
$\mathrm{Hz}) /{ }^{13} \mathrm{C}$ NMR $\left(100 \mathrm{MHz}, \mathrm{CDCl}_{3}\right): \delta 169.2,168.1,82.7,70.0,29.8,25.7,23.5,17.7$ / ESI: not detected / Rf: $0.58\left(\mathrm{CHCl}_{3} /\right.$ EtOAc: $\left.7 / 3\right)$

TCO-NHS Ester (11). Reagent available commercially from Click Chemistry Tools.

DIBAC (DBCO-NHS Ester) (12). Reagent available commercially from Click Chemistry Tools.

Bicyclo[6.1.0]non-4-yn-9-ylmethyl (4-nitrophenyl) carbonate (13). Compound (13) was obtained according to the method described previously. ${ }^{1}$ To a solution of 1,5-cyclooctadiene (45 mL, 0.362 mol, 8 eq) and $\mathrm{Rh}_{2}(\mathrm{OAc})_{4}(1 \mathrm{~g}, 2.26 \mathrm{mmol}, 0.05 \mathrm{eq})$ in anhydrous $\mathrm{CH}_{2} \mathrm{Cl}_{2}(50 \mathrm{~mL})$ was added dropwise under inert gas in 3 hours a solution of ethyl diazoacetate $(5.5 \mathrm{~mL}, 45 \mathrm{mmol}, 1 \mathrm{eq})$ in anhydrous $\mathrm{CH}_{2} \mathrm{Cl}_{2}(10 \mathrm{~mL})$. The solution was stirred for 2 days, the residue was concentrated in vacuo and the excess of cyclooctadiene was removed by filtration over a glass filter filled silica and eluted with a mixture 200:1 (Heptane:EtOAc). While endo and exo compounds can be separated, they were kept as a mixture given the low impact on cycloaddition reaction kinetics reported. The mixture of isomers $($ Endo/Exo $=2: 1)$ was obtained as a colorless oil $(4.13 \mathrm{~g}, 48 \%)$. Endo: $\mathrm{Rf}_{\text {endo }}$ : 0,31 (Heptane: EtOAc 95:5) / Exo: $\mathrm{Rf}_{\text {exo: }}$ 0,22 (Heptane:EtOAc 95:5) / ${ }^{1} \mathrm{H}$ NMR (400 MHz, $\mathrm{CDCl}_{3}$ ): 5.64-5.59 (m, $2 \mathrm{H}, \mathrm{CH}_{\text {endo+exo }}$ ), 4.10 (q, $2 \mathrm{H}, 7.2 \mathrm{~Hz}, \mathrm{CH}_{2 \text { endo+exo }}$ ), 2.55-2.45 (m, $\left.1.31 \mathrm{H}, 2 \mathrm{xCH}_{\text {endo }}\right), 2.34-2.26(\mathrm{~m}, 0.69 \mathrm{H}$, $\left.2 \mathrm{xCH}_{\text {exo }}\right), 2.24-2.15\left(\mathrm{~m}, 2 \mathrm{H}, \mathrm{m}, 2 \mathrm{xCH}_{\text {endo+exo }}\right), 2.12-2.01\left(\mathrm{~m}, 2 \mathrm{H}, \mathrm{m}, 2 \mathrm{xCH}_{\text {endo+exo }}\right), 1.87-1.78$ (m, $\left.1.30 \mathrm{H}, 2 \mathrm{xCH}_{\text {endo }}\right), 1.70\left(\mathrm{t}, 0.65 \mathrm{H}, 8.8 \mathrm{~Hz}, \mathrm{CH}_{\text {endo }}\right), 1.59-1.54\left(\mathrm{~m}, 0.71 \mathrm{H}, 2 \mathrm{xCH}_{\text {exo }}\right), 1.52-1.43(\mathrm{~m}$, $\left.0.74 \mathrm{H}, 2 \mathrm{xCH}_{\text {exo }}\right), 1.42-1.36\left(\mathrm{~m}, 1.33 \mathrm{H}, 2 \mathrm{xCH}_{\text {endo }}\right), 1.26\left(\mathrm{t}, 2 \mathrm{H}, 7.2 \mathrm{~Hz}, \mathrm{CH}_{3 \text { endo }}\right), 1.25$ (t, $1.05 \mathrm{H}, 7.2 \mathrm{~Hz}$, $\mathrm{CH}_{3 \text { exo }}$ ), 1.18 (t, $4.4 \mathrm{~Hz}, 0.36 \mathrm{H}, \mathrm{CH}_{\text {exo }}$ ) / ${ }^{13} \mathrm{C} \mathrm{NMR} \mathrm{(100} \mathrm{MHz,} \mathrm{CDCl}_{3}$ ): $\delta 174.6$ (exo), 172.4 (endo), 130.1 (exo), 129.6 (endo), 60.4 (exo), 59.9 (endo), 28.4 (exo), 28.0 (exo), 27.9 (exo), 27.2 (endo), 26.8 (exo), 24.3 (endo), 22.8 (endo), 21.4 (endo), 14.5 (endo), 14.4 (exo).

To a suspension of $\mathrm{LiAlH}_{4}(277 \mathrm{mg}, 6.95 \mathrm{mmol}, 0.9 \mathrm{eq})$ in anhydrous $\mathrm{Et}_{2} \mathrm{O}(25 \mathrm{~mL})$ was added dropwise at $0^{\circ} \mathrm{C}$ under stirring a solution of esters obtained previously $(1.5 \mathrm{~g}, 7.72 \mathrm{mmol})$ in anhydrous $\mathrm{Et}_{2} \mathrm{O}(10 \mathrm{~mL})$. After addition, the solution was stirred for 15 minutes at room temperature. The solution was then cooled down to $0^{\circ} \mathrm{C}$ and $\mathrm{H}_{2} \mathrm{O}$ was added carefully until the grey solid had turned white (release of dihydrogen, elimination of excess $\left.\mathrm{LiAlH}_{4}\right) \cdot \mathrm{MgSO}_{4}(5 \mathrm{~g})$ was added, and the solid was filtered and washed with cold $\mathrm{Et}_{2} \mathrm{O}(2 \times 50 \mathrm{~mL})$. The filtrate was concentrated under reduced pressure. The desired alcohols (endo/exo) were obtained as colorless oil (1.05 g, $90 \%)$ and were used as such in the following step.

To a solution of the alcohols obtained previously $(1.05 \mathrm{~g}, 6.9 \mathrm{mmol})$ in anhydrous $\mathrm{CH}_{2} \mathrm{Cl}_{2}(30 \mathrm{~mL})$, was added $\mathrm{Br}_{2}$ dropwise at $0^{\circ} \mathrm{C}$ under stirring $(393 \mu \mathrm{L}, 7.6 \mathrm{mmol}, 1.1 \mathrm{eq})$ in anhydrous $\mathrm{CH}_{2} \mathrm{Cl}_{2}(10$ $\mathrm{mL}$ ) until the yellow colour persisted (equivalence point). The solution was then brought to room temperature and the reaction was quenched with a few drops of a $10 \% \mathrm{Na}_{2} \mathrm{~S}_{2} \mathrm{O}_{3}$ solution (elimination of excess $\left.\mathrm{Br}_{2}\right)$. The reaction mixture was extracted with $\mathrm{CH}_{2} \mathrm{Cl}_{2}(2 \times 30 \mathrm{~mL})$. The organics layers were 
combined, dried over $\mathrm{MgSO}_{4}$ and concentrated in vacuo. The desired dibromides (endo/exo) were obtained as white solid (2.13 g, $99 \%)$ and were used as such in the following step.

To a solution of dibromides under argon obtained previously $(2.05 \mathrm{~g}, 6.57 \mathrm{mmol})$ in anhydrous THF $(30 \mathrm{~mL})$ was added dropwise at $0^{\circ} \mathrm{C}$ and under stirring a solution of $1 \mathrm{M}{ }^{\mathrm{t}} \mathrm{BuOK}$ in anhydrous $\mathrm{THF}$ (21.7 mL, $21.7 \mathrm{mmol}, 3.3 \mathrm{eq}$ ). The solution was then refluxed for 2 hours. After cooling down to room temperature the mixture was quenched with a saturated $\mathrm{NH}_{4} \mathrm{Cl}$ solution $(2 \times 30 \mathrm{~mL})$, extracted with $\mathrm{CH}_{2} \mathrm{Cl}_{2}(3 \times 20 \mathrm{~mL})$. The organic layers were combined, dried over $\mathrm{MgSO}_{4}$ and concentrated in vacuo. The crude product was purified on silica gel (Hept/EtOAc) to give the desired compounds (endo/exo, 2:1) as white solid (462 mg, $47 \%$ ). $\mathrm{Rf}_{\text {endo }}: 0.22$ (Hept/EtOAc: 1:1) / $\mathrm{Rf}_{\text {exo }}: 0.25$ (Hept/EtOAc: 1:1) / ${ }^{1} \mathrm{H}$ NMR (400 MHz, $\mathrm{CDCl}_{3}$ ): $\delta 3.73$ (d, 1.32H, $8 \mathrm{~Hz}, \mathrm{CH}_{2 \text { endo }}$ ), 3.54 (d, 0.67H, $6 \mathrm{~Hz}, \mathrm{CH}_{2 \mathrm{exo}}$ ), 2.43-2.14 $\left(\mathrm{m}, 6 \mathrm{H}, 3 \mathrm{CH}_{2 \text { endo }}+3 \mathrm{CH}_{2 \mathrm{exo}}\right), 1.65-1.59\left(\mathrm{~m}, 1.72 \mathrm{H}, 2 \mathrm{H}_{\text {endo }}+1 \mathrm{H}_{\text {exo }}\right), 1.55-1.34\left(\mathrm{~m}, 2.03 \mathrm{H}, 2 \mathrm{H}_{\text {endo }}+2 \mathrm{H}_{\text {exo }}\right)$, 0.96-0.91 (m, 1.32H, 2xH $\left.\mathrm{H}_{\text {endo }}\right), 0.69-0.66\left(\mathrm{~m}, 1.05 \mathrm{H}, 3 \mathrm{H}_{\text {exo }}\right) /{ }^{13} \mathrm{C} \mathrm{NMR}\left(100 \mathrm{MHz}, \mathrm{CDCl}_{3}\right): \delta 98.22$ (exo), 98.0 (endo), 66.3 (exo), 59.2 (endo), 32.6 (exo), 28.2 (endo), 26.5 (exo), 21.8 (exo), 20.7 (endo), 20.6 (exo), 20.6 (endo), 19.20 (endo).

To a solution of bicyclononynes obtained previously $(80 \mathrm{mg}, 0.53 \mathrm{mmol})$ under argon in anhydrous $\mathrm{CH}_{2} \mathrm{Cl}_{2}(10 \mathrm{~mL})$ was added pyridine $(108 \mu \mathrm{L}, 1.33 \mathrm{mmol}, 2.5 \mathrm{eq})$. After stirring for 5 minutes, 4nitrophenyl carbonochloridate $(0.145 \mathrm{~g}, 0.692 \mathrm{mmol}, 1.3 \mathrm{eq})$ was added in one portion in the solution and the mixture was stirred for 15 minutes. The solution was treated with saturated $\mathrm{NH}_{4} \mathrm{Cl}$ solution (15 $\mathrm{mL})$, extracted with $\mathrm{CH}_{2} \mathrm{Cl}_{2}(3 \times 10 \mathrm{~mL})$. The organics layers were combined, dried over $\mathrm{MgSO}_{4}$ and concentrated in vacuo. The crude product was purified on silica gel (Hept/EtOAc) to give the desired compounds (13) as white solid (85 mg, $51 \%$ ). ${ }^{1} \mathrm{H} \mathrm{NMR}\left(400 \mathrm{MHz}, \mathrm{CDCl}_{3}\right): \delta 8.26$ (d, 2H, 2CH $\mathrm{CH}_{\text {endo-exo, }}$

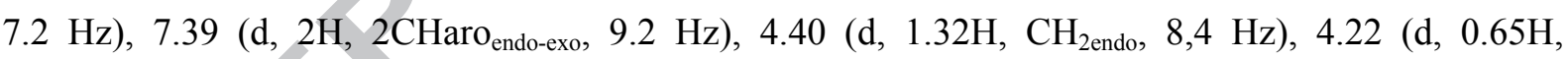
$\left.\mathrm{CH}_{2 \mathrm{exo}}, 6.8 \mathrm{~Hz}\right), 2.47-2.13\left(\mathrm{~m}, 6 \mathrm{H}, 3 \mathrm{CH}_{2 \text { endo }}+3 \mathrm{CH}_{2 \mathrm{exo}}\right), 1.67-1.56\left(\mathrm{~m}, 1.68 \mathrm{H}, 2 \mathrm{H}_{\text {endo }}+1 \mathrm{H}_{\text {exo }}\right), 1.55-1.34$ $\left(\mathrm{m}, 21.97 \mathrm{H}, 2 \mathrm{H}_{\text {endo }}+2 \mathrm{H}_{\text {exo }}\right), 1.09-1.04\left(\mathrm{~m}, 1.32 \mathrm{H}, 2 \mathrm{xH}_{\text {endo }}\right), 0.90-0.79\left(\mathrm{~m}, 1.07 \mathrm{H}, 3 \mathrm{H}_{\text {exo }}\right) /{ }^{13} \mathrm{C} \mathrm{NMR}$ (100 MHz, $\mathrm{CDCl}_{3}$ ): $\delta 155.8$ (endo), 152.8 (endo),.152.7 (exo), 145.6 (endo), 125.4 (endo), 121.9 (endo), 121.9 (exo), 98.9 (endo), 98.8 (exo), 68.1 (endo), 33.3 (exo), 29.2 (endo), 23.5 (exo), 23.1 (exo), 21.5 (endo), 21.4 (exo), 20.7 (endo), 17.4 (endo) / Rf: 0.65 (Hept/EtOAc: 4:1) / ESI (+): not detected. 


\section{3) Clickable peptides}

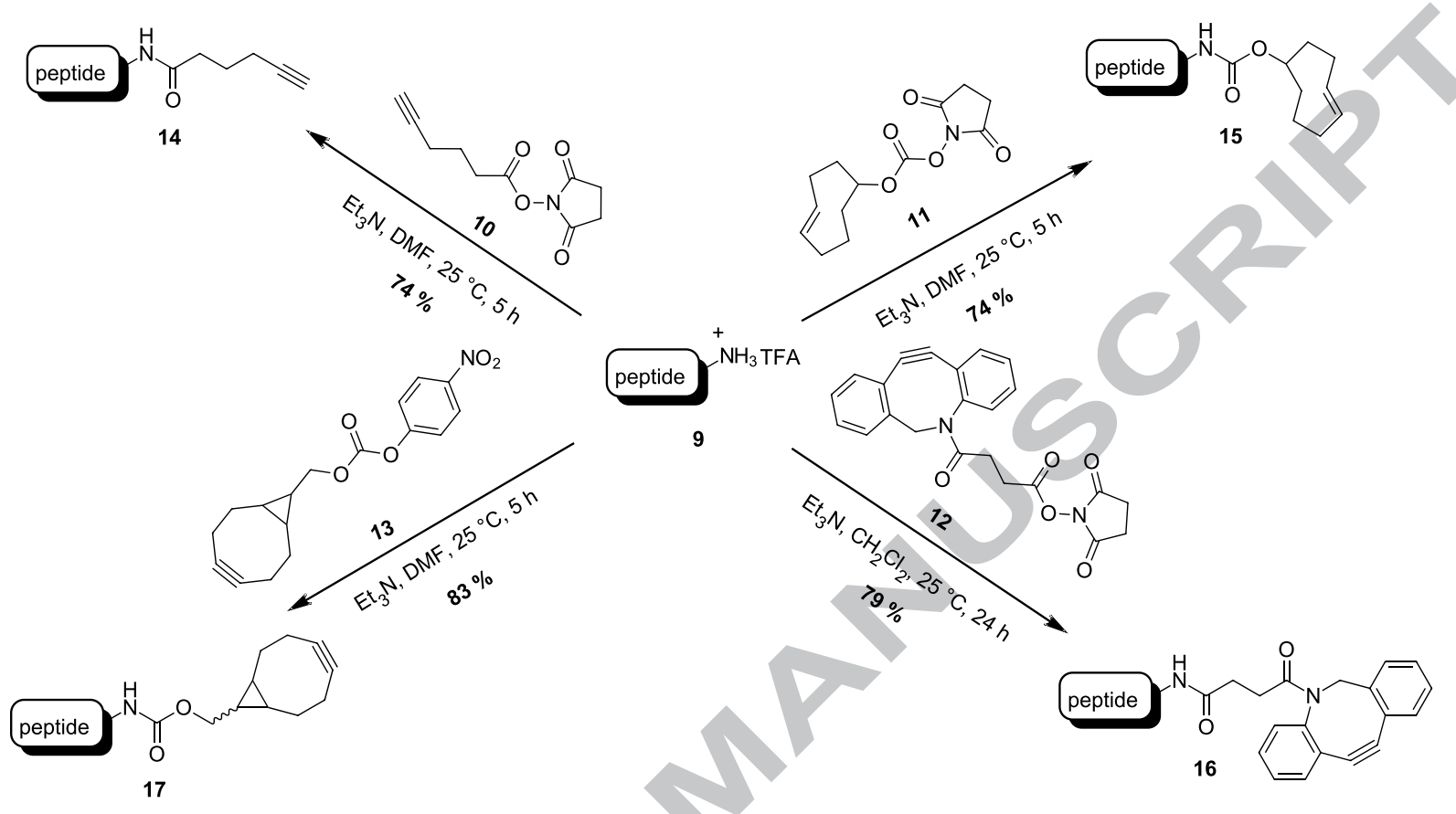

$N_{\alpha}$-(acetylglycyl)- $N_{\varepsilon}$-(hex-5-ynoyl)-lysylglycine ethyl ester (14). To a solution of $\mathrm{N} \alpha$-(acetylglycyl)lysylglycine ethyl ester trifluoroacetate salt (9) $(100 \mathrm{mg}, 0.23 \mathrm{mmol})$ in dry DMF $(10 \mathrm{~mL})$ was added $\mathrm{Et}_{3} \mathrm{~N}(99 \mu \mathrm{L}, 0.68 \mathrm{mmol}, 3 \mathrm{eq})$ and $N$-succinimidyl 5-hexynoate (10) (70.6 mg, $\left.0.34 \mathrm{mmol}, 1.5 \mathrm{eq}\right)$. The solution was stirred for 5 hours under argon. Then the crude product was concentrated under reduced pressure and directly purified on silica gel $\left(\mathrm{CHCl}_{3} / \mathrm{MeOH}\right)$ to give the desired compound as white solid (71 mg, 74\%). ${ }^{1} \mathrm{H}$ NMR (400 MHz, DMSO- $\left.d_{6}\right): \delta 8.32$ (s, NH), 8.05 (s, NH), 7.94 (s, NH), 7.73 (s, NH), 4.28-4.23 (m, 1H), 4.08 (q, 2H, $4 \mathrm{~Hz}), 3.81$ (t, 2H, $8 \mathrm{~Hz}), 3.71$ (d, 2H, $\left.\mathrm{CH}_{2}, 4 \mathrm{~Hz}\right), 3.01$ (q, 2H, $8 \mathrm{~Hz}), 2.74(\mathrm{~s}, 1 \mathrm{H}), 2.16-2.12(\mathrm{~m}, 4 \mathrm{H}), 1.85\left(\mathrm{~s}, 3 \mathrm{H}, \mathrm{CH}_{3}\right), 1.69-1.63(\mathrm{~m}, 3 \mathrm{H}), 1.56-1.46(\mathrm{~m}$, 1H), 1.41-1.31 (m, 2H), 1.31-1.23 (m, 2H), $1.18\left(\mathrm{t}, 3 \mathrm{H}, \mathrm{CH}_{3}, 7.2 \mathrm{~Hz}\right) /{ }^{13} \mathrm{C}$ NMR (100 MHz, DMSO$\left.d_{6}\right): \delta 172.0,171.2,171.1,169.5,168.8,84.1,71.4,60.3,52.1,41.9,40.6,38.3,34.1,31.7,28.8,24.2$, 22.5, 22.4, 17.4, $14.0 / \mathrm{t}_{\mathrm{R}}: 2.11 \mathrm{~min} / \mathrm{HRMS}$ : calculated for $\mathrm{C}_{20} \mathrm{H}_{32} \mathrm{~N}_{4} \mathrm{O}_{6} \mathrm{Na} \mathrm{M}(+)$ : 447.2220, found: 447.2202 .

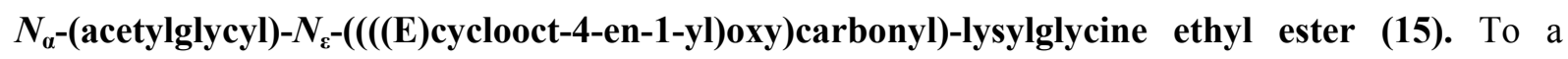
solution of $\mathrm{N} \alpha$-(acetylglycyl)-lysylglycine ethyl ester trifluoroacetate salt (9) (83 $\mathrm{mg}, 0.18 \mathrm{mmol}, 2 \mathrm{eq}$ ) in dry DMF $(10 \mathrm{~mL})$ was added $\mathrm{Et}_{3} \mathrm{~N}(78 \mu \mathrm{L}, 0.56 \mathrm{mmol}, 6 \mathrm{eq})$ and (E)-cyclooct-4-en-1-yl (2,5dioxopyrrolidin-1-yl) carbonate (11) $(25 \mathrm{mg}, 0.093 \mathrm{mmol}, 1 \mathrm{eq})$. The solution was stirred for 5 hours under argon. Then the crude product was concentrated under reduced pressure and directly purified on silica gel $\left(\mathrm{CHCl}_{3} / \mathrm{MeOH}\right)$ to give the desired compound as white solid (33 mg, $\left.74 \%\right)$. ${ }^{1} \mathrm{H}$ NMR (400 
MHz, DMSO- $\left.d_{6}\right): \delta 8.32(\mathrm{~s}, \mathrm{NH}), 8.04(\mathrm{~s}, \mathrm{NH}), 7.94(\mathrm{~s}, \mathrm{NH}), 6.89(\mathrm{~s}, \mathrm{NH}), 5.69-5.53(\mathrm{~m}, 1.41 \mathrm{H}$, $=\mathrm{CH}), 5.47-5.39(\mathrm{~m}, 0.66 \mathrm{H},=\mathrm{CH}), 4.61-4.52(\mathrm{~m}, 0.41 \mathrm{H}), 4.27-4.19(\mathrm{~m}, 1.64 \mathrm{H}), 4.08(\mathrm{q}, 2 \mathrm{H}, 8 \mathrm{~Hz})$, 3.80 (t, 2H, 4 Hz), 3.71 (d, 2H, 8 Hz), 2.93-2.89 (m, 2H), 2.34-1.97 (m, 4H), 1.92-1.71 (m, 6H), 1.69$1.43(\mathrm{~m}, 5 \mathrm{H}), 1.40-1.31(\mathrm{~m}, 2 \mathrm{H}), 1.28-1.22(\mathrm{~m}, 2 \mathrm{H}), 1.18(\mathrm{t}, 3 \mathrm{H}, 8 \mathrm{~Hz}) /{ }^{13} \mathrm{C}$ NMR (100 MHz, DMSO$\left.d_{6}\right): \delta 172.0,169.6,169.5,168.8,155.7,134.9,132.5,74.9,74.2,60.3,52.2,42.0,40.6,38.2,33.7$, 32.1, 31.7, 30.6, 29.1, 25.1, 24.5, 22.4, 21.9, 14.0 / HRMS: calculated for $\mathrm{C}_{23} \mathrm{H}_{38} \mathrm{~N}_{4} \mathrm{O}_{7} \mathrm{Na} \mathrm{M}(+)$ : 505.2638 , found : $505.2656 / \mathrm{t}_{\mathrm{R}}: 4.04 \mathrm{~min}$.

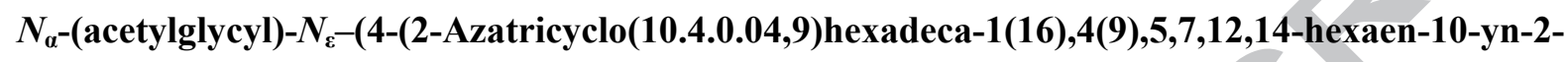
yl)-4-oxobutyryl)-lysylglycine ethyl ester (16). To a solution of $\mathrm{N} \alpha$-(acetylglycyl)-lysylglycine ethyl ester trifluoroacetate salt (9) (38mg, $84 \mu \mathrm{mol}, 1.2 \mathrm{eq})$ in anhydrous $\mathrm{CH}_{2} \mathrm{Cl}_{2}(5 \mathrm{~mL})$, was added $\mathrm{Et}_{3} \mathrm{~N}$ (35 $\mu \mathrm{L}, 251 \mu \mathrm{mol} .3 .6 \mathrm{eq}$ ) and DBCO-NHS ester (12) (28 mg, $69 \mu \mathrm{mol}, 1.0 \mathrm{eq})$. The solution was stirred for 24 hours under argon at room temperature. The solution was washed with $\mathrm{H}_{2} \mathrm{O}$, dried over $\mathrm{MgSO}_{4}$ and concentrated in vacuo. The crude product was purified on silica gel $\left(\mathrm{CHCl}_{3} / \mathrm{MeOH}, 9 / 1\right)$ to give the desired compound as a white solid (34 mg, $79 \%$ ). ${ }^{1} \mathrm{H}$ NMR (400 MHz, $\mathrm{CHCl}_{3}$ ): $\delta 7.70$ 7.57 (m, 2H), 7.55-7.52 (m, NH), 7.48-7.46 (m, 1H), 7.40-7.35 (m, 3H), 7.24-7.17 (m, 2H), 7.11-7.07 $(\mathrm{m}, \mathrm{NH}), 6.68-6.62(\mathrm{NH}), 6.52-6.48(\mathrm{NH}), 5.15-5.07(\mathrm{~m}, 1 \mathrm{H}, \mathrm{CH}), 4.56-4.43(\mathrm{~m}, 1 \mathrm{H}), 4.13(\mathrm{q}, 2 \mathrm{H}, 7.2$ $\mathrm{Hz}), 4.02-3.90(\mathrm{~m}, 2 \mathrm{H}), 3.87-3.81(\mathrm{~m}, 1 \mathrm{H}, \mathrm{CH}), 3.76-3.59(\mathrm{~m}, 2 \mathrm{H}), 3.35-3.21(\mathrm{~m}, 0.5 \mathrm{H}), 3.10-2.98(\mathrm{~m}$, $1 \mathrm{H}), 2.96-2.81(\mathrm{~m}, 1 \mathrm{H}), 2.78-2.66(\mathrm{~m}, 0.5 \mathrm{H}), 2.37-2.26(\mathrm{~m}, 1 \mathrm{H}), 2.19-2.05(\mathrm{~m}, 1 \mathrm{H}), 1.94\left(\mathrm{~s}, 3 \mathrm{H}, \mathrm{CH}_{3}\right)$, 1.91-1.71 (m, 2H), 1.69-1.56 (m, 1H), 1.50-1.27 (m, 4H), $1.22(\mathrm{t}, 3 \mathrm{H}, 7.2 \mathrm{~Hz}) /{ }^{13} \mathrm{C} \mathrm{NMR}(100 \mathrm{MHz}$, $\left.\mathrm{CHCl}_{3}\right): 172.8,172.7,172.5,172.5,172.4,172.3,171.5,171.3,170.0,169.9,169.7,151.3,151.3$, $148.3,148.2,132.4,132.3,129.6,128.9,128.8,128.4,128.4,128.3,128.0,127.8,127.3,127.1,125.6$, $125.6,123.3,123.2,122.6,122.5,114.8,114.7,108.0,114.7,108.0,107.9,77.3,61.5,61.5,53.1$, 53.0, 43.4, 43.2, 41.2, 38.8, 38.8, 31.6, 31.3, 30.9, 30.5, 30.2, 28.6, 28.4, 22.9, 22.8, 22.2, 14.2, 14.2 / HRMS: calculated for $\mathrm{C}_{33} \mathrm{H}_{40} \mathrm{~N}_{5} \mathrm{O}_{7} \mathrm{M}(+): 618.2928$, found : $618.2755 / \mathrm{t}_{\mathrm{R}}: 5.33 \mathrm{~min}$

$N_{\alpha^{-}}$-(acetylglycyl)- $N_{\varepsilon}-(($ bicyclo[6.1.0]non-4-yn-9-ylmethoxy)carbonyl)-lysylglycine ethyl ester (17). To a solution of $\mathrm{N \alpha}$-(acetylglycyl)-lysylglycine ethyl ester trifluoroacetate salt (9) (117 mg, 0.27 mmol, $1.2 \mathrm{eq})$ in anhydrous DMF $(10 \mathrm{~mL})$ was added $\mathrm{Et}_{3} \mathrm{~N}(92 \mu \mathrm{L}, 0.66 \mathrm{mmol}, 3 \mathrm{eq})$ and bicyclo[6.1.0]non-4-yn-9-ylmethyl (4-nitrobenzyl) carbonate (13) (69 mg, $0.22 \mathrm{mmol}, 1 \mathrm{eq})$. The solution was stirred for 5 hours under inert gas. Then the crude product was concentrated under reduced pressure and directly purified on silica gel $\left(\mathrm{CHCl}_{3} / \mathrm{MeOH}\right)$ to give the desired compound as white solid (92 mg, $83 \%$ ). ${ }^{1} \mathrm{H}$ NMR (400 MHz, DMSO- $\left.d_{6}\right): \delta 8.33$ (s, NH), 8.05 (s, NH), 7.96 (s, $\mathrm{NH}), 7.05$ (s, NH), 4.28-4.22 (m, 1H), 4.11-4.07 (q, 2H, 7.2 Hz), 4.05-4.01 (m, 1.31H), 3.86-3.82 (m, 0.62H), 3.81-3.79 (t, 2H, 5.6 Hz), $3.71(\mathrm{~d}, 2 \mathrm{H}, 6 \mathrm{~Hz}), 2.95-2.91(\mathrm{~m}, 2 \mathrm{H}), 2.36-1.89(\mathrm{~m}, 6 \mathrm{H}), 1.84(\mathrm{~s}$, $\left.3 \mathrm{H}, \mathrm{CH}_{3}\right), 1.70-1.61(\mathrm{~m}, 1 \mathrm{H}), 1.55-1.46(\mathrm{~m}, 2 \mathrm{H}), 1.38-1.24(\mathrm{~m}, 5 \mathrm{H}), 1.18(\mathrm{t}, 3 \mathrm{H}, 7.2 \mathrm{~Hz}), 1.04(\mathrm{~d}$, $0.65 \mathrm{H}, 6.4 \mathrm{~Hz}), 0.90-0.71(\mathrm{~m}, 1.32 \mathrm{H}), 0.71-0.59(\mathrm{~m}, 1 \mathrm{H}) /{ }^{13} \mathrm{C}$ NMR (100 MHz, DMSO- $\left.d_{6}\right): \delta 172.0$, 169.6, 169.5, 168.9, 156.3, 99.0, 98.9, 67.6, 61.2, 60.3, 54.9, 52.2, 42.0, 40.7, 32.9, 31.8, 29.1, 28.6, 
25.5, 23.4, 22.4, 22.2, 20.8, 19.5, 17.6, 14.0 / HRMS: calculated for $\mathrm{C}_{25} \mathrm{H}_{38} \mathrm{~N}_{4} \mathrm{O}_{7} \mathrm{Na} \mathrm{M}(+)$ : 529.2638, found : $529.2644 / t_{R}: 3.50 \mathrm{~min}$.

\section{4) Clickable peptides and cold iodinated references conjugation}

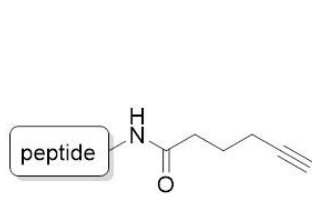

14

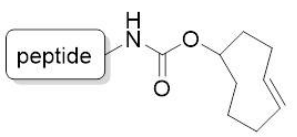

15

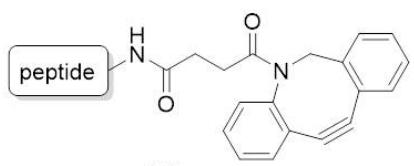

16

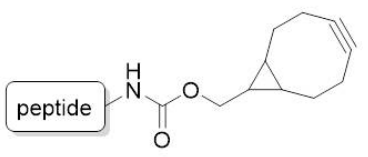

17

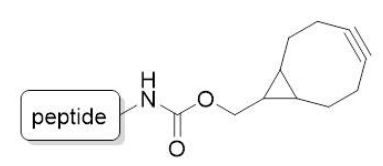

17

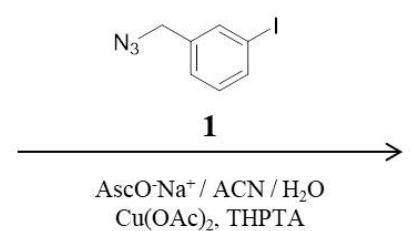

$32 \%$
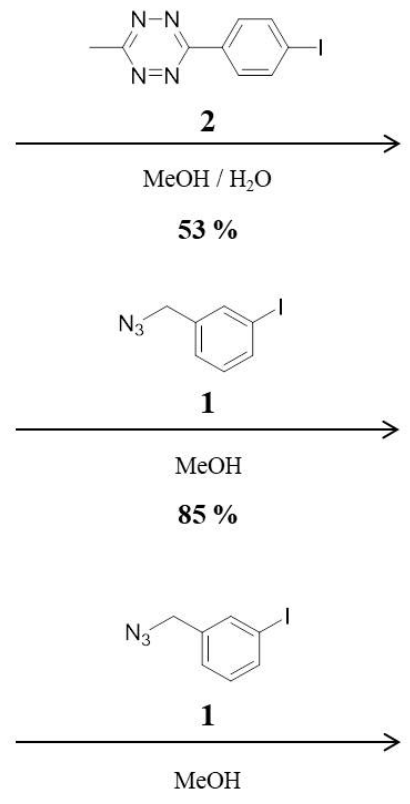

$62 \%$

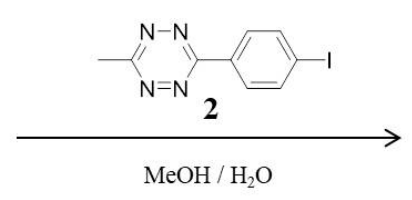

$60 \%$

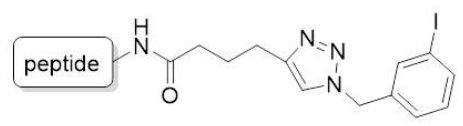

18

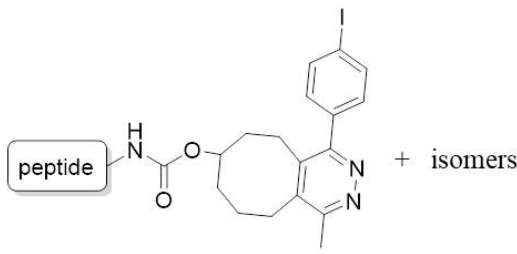

19

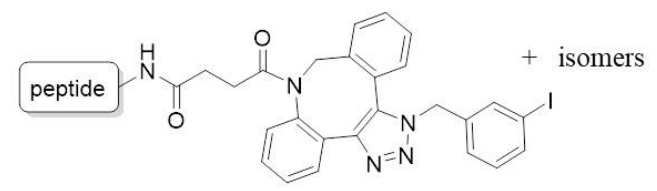

20

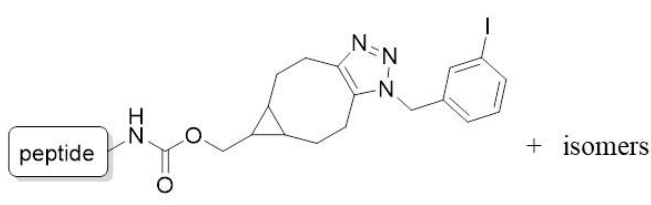

21

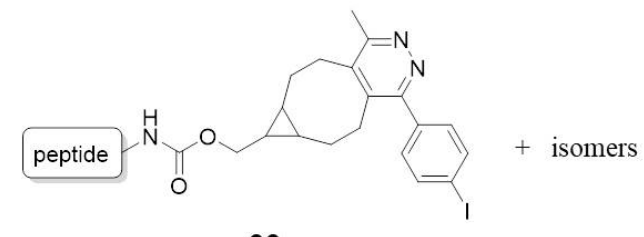

22

$N_{\alpha}$-(acetylglycyl)- $N_{\varepsilon}$-(4-(1-(3-iodobenzyl)-1H-1,2,3-triazol-4-yl)butanoyl)-lysylglycine ethyl ester (18). To a solution of $\mathbf{1 4}(32.2 \mathrm{mg}, 75.8 \mu \mathrm{mol})$ in methanol $(1.9 \mathrm{~mL})$ was added 3-iodobenzylazide (1) (17.7 mg, $68.3 \mu \mathrm{mol}, 0.9 \mathrm{eq})$ dissolved in $\mathrm{MeOH}(500 \mu \mathrm{L})$. Then, sodium ascorbate (1,5 mg, 7,6 $\mu \mathrm{mol}$, $0.1 \mathrm{eq})$ in water $(2 \mathrm{~mL})$, copper sulphate $(0.19 \mathrm{mg}, 758 \mathrm{nmol}, 0.01 \mathrm{eq})$ in water $(500 \mu \mathrm{L})$ and THPTA $(0.33 \mathrm{mg}, 758 \mathrm{nmol}, 0.01 \mathrm{eq})$ in $\mathrm{MeOH}(500 \mu \mathrm{L})$ were added. The milky solution was stirred overnight at room temperature and turned clear. The crude product was concentrated under reduced pressure and 
directly purified on silica gel $\left(\mathrm{CHCl}_{3} / \mathrm{MeOH}\right.$ 9:1) to give the desired compound as colorless oil (15 mg, 32 \%). ${ }^{1} \mathrm{H}$ NMR (400 MHz, $\left.\mathrm{CD}_{3} \mathrm{OD}\right): \delta 7.79$ (s, 1H), $7.71(\mathrm{~s}, 1 \mathrm{H}), 7.69$ (s, 1H), $7.31(\mathrm{~d}, 1 \mathrm{H}, 8$ Hz), 7.14 (t, 1H, 8 Hz), 5.52 (s, 2H, $\mathrm{CH}_{2}$ ), 4.42-4.35 (m, 1H), 4.16 (q, 2H, $\left.\mathrm{CH}_{2}, 7.2 \mathrm{~Hz}\right), 3.91$ (d, 2H, 6 $\mathrm{Hz}$ ), 3.86 (s, 2H), 3.16 (t, 2H, CH, $6.4 \mathrm{~Hz}), 2.71$ (t, 2H, $\left.\mathrm{CH}_{2}, 7.6 \mathrm{~Hz}\right), 2.23$ (t, 2H, $\left.\mathrm{CH}_{2}, 7.6 \mathrm{~Hz}\right), 2.00$ (s, 3H, $\left.\mathrm{CH}_{3}\right), 1.95$ (t, 2H, CH $\left.2,7.6 \mathrm{~Hz}\right), 1.91-1.83(\mathrm{~m}, 1 \mathrm{H}), 1.74-1.64(\mathrm{~m}, 1 \mathrm{H}), 1.57-1.48(\mathrm{~m}, 2 \mathrm{H})$, 1.46-1.36 (m, 2H), 1.25 (t, 3H, $\left.\left.\mathrm{CH}_{3}, 7.2 \mathrm{~Hz}\right) /{ }^{13} \mathrm{C} \mathrm{NMR} \mathrm{(100} \mathrm{MHz,} \mathrm{CD}_{3} \mathrm{OD}\right): \delta 175.5,174.7,174.0$, 171.7, 171.2, 149.0, 139.4, 138.7, 138.1, 131.8, 128.4, 123.6, 95.2, 62.3, 54.5, 53.9, 43.7, 42.1, 40.1, 36.4, 32.6, 29.9, 26.7, 25.8, 24.0, 22.5, 14.5 / HRMS: calculated for $\mathrm{C}_{27} \mathrm{H}_{39} \mathrm{IN}_{7} \mathrm{O}_{6} \mathrm{M}(+)$ : 684.2007 , found : $684.2005 / \mathrm{t}_{\mathrm{R}}: 4.12 \mathrm{~min}$.

$N_{\alpha^{-}}$-(acetylglycyl)- $N_{\varepsilon}$-(((1-(4-iodophenyl)-4-methyl-5,6,7,8,9,10-hexahydrocycloocta[d] pyridazin7-yl)oxy)carbonyl)-lysylglycine ethyl ester (19). To a solution of (15) $(9.8 \mathrm{mg}, 20.3 \mu \mathrm{mol}, 1 \mathrm{eq})$ in a mixture $\mathrm{H}_{2} \mathrm{O} / \mathrm{MeOH}$ 1:1 (1 mL) was added 3-(4-iodophenyl)-6-methyl-1,2,4,5-tetrazine (2) $(6.7 \mathrm{mg}$, $22.6 \mu \mathrm{mol}, 1.1 \mathrm{eq})$. The solution was stirred for 5 hours under inert gas. The crude product was concentrated under reduced pressure and directly purified on silica gel $\left(\mathrm{CHCl}_{3} / \mathrm{MeOH}\right)$ to give the desired compound as white solid (8 mg, $53 \%$ ). ${ }^{1} \mathrm{H}$ NMR (400 MHz, $\left.\mathrm{CD}_{3} \mathrm{CN}\right): \delta 7.84(\mathrm{~d}, 2 \mathrm{H}, 6.4 \mathrm{~Hz})$, 7.22 (t, 2H, 6.4 Hz), 7.19-7.10 (m, NH), 7.01-6.90 (m, NH), 6.90-6.74 (m, NH), 5.50-5.35 (m, NH), 4.48-4.38 (m, 1H, CH), 4.29-4.19 (m, 1H), 4.12-4.06 (q, 2H, 7.2 Hz), 3.86-3.76 (m, 2H), 3.76-3.60 (m, $2 \mathrm{H}), 3.06-2.92(\mathrm{~m}, 2 \mathrm{H}), 2.92-2.78(\mathrm{~m}, 2 \mathrm{H}), 2.67\left(\mathrm{~s}, 3 \mathrm{H}, \mathrm{CH}_{3}\right), 2.63-2.50(\mathrm{~m}, 2 \mathrm{H}), 1.92-1.77(\mathrm{~m}+\mathrm{s}$, $\left.6 \mathrm{H}, \mathrm{CH}_{3}+3 \mathrm{H}\right), 1.77-1.70(\mathrm{~m}, 1 \mathrm{H}), 1.65-1.50(\mathrm{~m}, 4 \mathrm{H}), 1.45-1.32(\mathrm{~m}, 2 \mathrm{H}), 1.32-1.22(\mathrm{~m}, 2 \mathrm{H}), 1.19(\mathrm{t}$, $\left.3 \mathrm{H}, \mathrm{CH}_{3}, 7.2 \mathrm{~Hz}\right) /{ }^{13} \mathrm{C} \mathrm{NMR}\left(100 \mathrm{MHz}, \mathrm{CD}_{3} \mathrm{CN}\right): \delta 173.1,171.9,171.8,170.7,170.4,170.3,129.2$, 139.1, 138.4, 132.1, 132.0, 130.5, 61.8, 54.0, 53.9, 44.0, 41.8, 41.1, 41.0, 36.2, 36.1, 34.5, 34.4, 32.1, 32.0, 30.1, 31.0, 24.8, 24.3, 24.2, 23.3, 22.9, 21.9, 20.5, 14.5 / HRMS: calculated for $\mathrm{C}_{32} \mathrm{H}_{44} \mathrm{IN}_{6} \mathrm{O}_{7}$ $\mathrm{M}(+)$ : 751.2316 , found : $751.2319 / \mathrm{t}_{\mathrm{R}}: 6.3-7.6-8.2 \mathrm{~min}$.

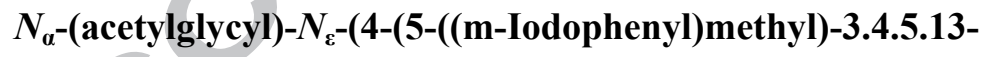

tetraazatetracyclo(13.4.0.0 $\left.{ }^{2,6} .0^{7,12}\right)$ nonadeca-1(19),2(6),3,7,9,11,15,17-octaen-13-yl)-4-oxobutyryl)lysylglycine ethyl ester (20). To a solution of 16 (33 mg, $53.4 \mu \mathrm{mol})$ in $\mathrm{MeOH}(4 \mathrm{~mL})$ was added compound 1 (16.6 mg, $64.1 \mu \mathrm{mol}, 1.2 \mathrm{eq})$ in $\mathrm{MeOH}(1 \mathrm{~mL})$. The solution was stirred for $30 \mathrm{~min}$ at room temperature. The crude product was concentrated under reduced pressure and directly purified on silica gel $\left(\mathrm{CHCl}_{3} / \mathrm{MeOH} 9: 1\right)$ to give the desired compound as colorless oil (39 mg, $\left.85 \%\right)$. ${ }^{1} \mathrm{H}$ NMR (400 MHz, $\left.\mathrm{CDCl}_{3}\right): \delta$ 7.71-7.54 (m, 4H), 7.52-7.49 (m, 1H), 7.47-7.32 (m, 3H), 7.24-7.19 (m, $2 \mathrm{H})$, 7.16-7.06 (m, 2H), 7.05-6.98 (m, NH), 6.93-6.91 (m, NH), 6.72-6.63 (m, NH), 6.51-6.40 (m, $\mathrm{NH}), 5.95(\mathrm{t}, 0.8 \mathrm{H}, 18.8 \mathrm{~Hz}), 5.79(\mathrm{t}, 0.4 \mathrm{H}, 15.2 \mathrm{~Hz}), 5.63-5.44(\mathrm{~m}, 1.2 \mathrm{H}), 5.30-5.24(\mathrm{~m}, 0.4 \mathrm{H}), 5.11-$ $5.03(\mathrm{~m}, 0.1 \mathrm{H}), 4.96-4.88(\mathrm{~m}, 0.1 \mathrm{H}), 4.57-4.26(\mathrm{~m}, 2 \mathrm{H}), 4.49-4.06(\mathrm{~m}, 2 \mathrm{H}), 4.00-3.70(\mathrm{~m}, 4 \mathrm{H}), 3.24-$ $2.87(\mathrm{~m}, 2 \mathrm{H}), 2.37-2.25(\mathrm{~m}, 1 \mathrm{H}), 2.22-2.01(\mathrm{~m}, 2 \mathrm{H}), 1.97(\mathrm{~s}, 3 \mathrm{H}), 1.90-1.71(\mathrm{~m}, 2 \mathrm{H}), 1.71-1.52(\mathrm{~m}$, 1H), 1.45-1.34 (m, 2H), 1.34-1.27 (m, 2H), $1.23(\mathrm{t}, 3 \mathrm{H}, 6.8 \mathrm{~Hz}) /{ }^{13} \mathrm{C} \mathrm{NMR}\left(100 \mathrm{MHz}, \mathrm{CDCl}_{3}\right): \delta$ 
$172.5,172.4,172.3,172.2,172.1,172.0,171.4,171.4,171.2,170.1,170.0,170.0,169.8,145.4,145.3$, $143.3,141.5,140.2,140.2,138.0,137.8,137.8,137.4,137.3,137.2,136.6,136.5,136.3,136.0,135.3$, 135.2 , 133.6, 132.7, 132.3, 132.2, 131.6, 131.5, 131.4, 131.3, 131.0, 130.9, 130.3, 130.0, 129.9, 129.7, $129.5,129.2,128.8,128.7,128.4,128.2,128.1,127.3,127.2,127.1,127.0,126.9,126.6,124.2,124.1$, $94.9,94.6,77.36,61.5,53.4,53.3,53.2,53.0,52.0,51.7,51.6,51.3,51.2,50.7,43.3,41.4,39.0,38.7$, $38.5,31.5,31.4,31.2,31.2,30.9,30.8,30.1,29.9,29.7,29.6,28.9,28.8,28.6,28.3,23.0,22.9,22.4$ / HRMS: calculated for $\mathrm{C}_{40} \mathrm{H}_{46} \mathrm{IN}_{8} \mathrm{O}_{7} \mathrm{M}(+): 877.2534$, found : $8.772554 / \mathrm{t}_{\mathrm{R}}: 6.19+6.51 \mathrm{~min}$.

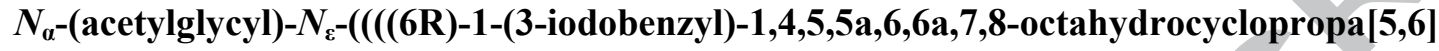

cycloocta[1,2-d][1,2,3]triazol-6-yl)methoxy)carbonyl)-lysylglycine ethyl ester (21). To a solution of 17 (33 mg, $65 \mu \mathrm{mol})$ in $\mathrm{MeOH}(4 \mathrm{~mL})$ was added compound 1 (16 mg, $62 \mu \mathrm{mol}, 0.95 \mathrm{eq})$ in $\mathrm{MeOH}$ $(1 \mathrm{~mL})$. The solution was stirred overnight at room temperature. The crude product was concentrated under reduced pressure and directly purified on silica gel $\left(\mathrm{CHCl}_{3} / \mathrm{MeOH}\right.$ 9:1) to give the desired compound as colorless oil (29 mg, $62 \%$ ). ${ }^{1} \mathrm{H}$ NMR (400 MHz, $\mathrm{CD}_{3} \mathrm{OD}$ ): $\delta 7.67$ (d, 1H, $6.8 \mathrm{~Hz}$ ), 7.47 (s, 1H), 7.17-7.11 (m, 2H), 5.59-5.50 (m, 2H, CH$), 4.40-4.37(\mathrm{~m}, 1 \mathrm{H}), 4.20-4.09(\mathrm{~m}, 3.32 \mathrm{H}), 3.92(\mathrm{~d}$, $2.65 \mathrm{H}, 5.6 \mathrm{~Hz}), 3.87(\mathrm{~s}, 2 \mathrm{H}), 3.16-3.03(\mathrm{~m}, 3 \mathrm{H}), 2.96-2.80(\mathrm{~m}, 2 \mathrm{H}), 2.72-2.58(\mathrm{~m}, 1 \mathrm{H}), 2.42-2.28(\mathrm{~m}$, $064 \mathrm{H}), 2.26-2.12(\mathrm{~m}, 1.34 \mathrm{H}), 2.01\left(\mathrm{~s}, 3 \mathrm{H}, \mathrm{CH}_{3}\right), 1.94-1.83(\mathrm{~m}, 1 \mathrm{H}), 1.73-1.61(\mathrm{~m}, 2 \mathrm{H}), 1.55-1.37(\mathrm{~m}$, $5 \mathrm{H}), 1.25\left(\mathrm{t}, 3 \mathrm{H}, \mathrm{CH}_{3}, 7.2 \mathrm{~Hz}\right), 1.10-0.95(\mathrm{~m}, 0.8 \mathrm{H}), 0.91-0.81(\mathrm{~m}, 1.4 \mathrm{H}), 0.78-0.67(\mathrm{~m}, 0.8 \mathrm{H}) /{ }^{13} \mathrm{C}$ NMR (100 MHz, $\left.\mathrm{CD}_{3} \mathrm{OD}\right): \delta 174.7,174.0,171.7,171.1,159.2,146.4,139.5,138.4,137.1,135.7$, 135.6, 131.8, 127.5, 127.4, 95.2, 69.3, 63.4, 62.3, 54.5, 51.7, 49.8, 43.8, 437, 42.2, 42.0, 41.4, 32.6, $30.8,30.5,28.0,27.1,26.4,26.1,25.6,23.9,23.6,23.5,23.4,23.3,23.3,22.5,22.4,20.5,20.2,18.8$, 14.5 / HRMS: calculated for $\mathrm{C}_{32} \mathrm{H}_{45} \mathrm{IN}_{7} \mathrm{O}_{7} \mathrm{M}(+)$ : 766.2425 , found : $766.2421 / \mathrm{t}_{\mathrm{R}}: 5.75 \mathrm{~min}$.

\section{$N_{\alpha}$-(acetylglycyl)- $N_{\varepsilon}-(((1-(4-i o d o p h e n y l)-4-m e t h y l-6,6 a, 7,7 a, 8,9-h e x a h y d r o-5 H$-cyclopropa}

[5,6]cycloocta[1,2-d]pyridazin-7-yl)methoxy)carbonyl)-lysylglycine ethyl ester (22). To a solution of (17) $(10 \mathrm{mg}, 19.7 \mu \mathrm{mol})$ in a mixture $\mathrm{H}_{2} \mathrm{O} / \mathrm{MeOH} 1: 1(1 \mathrm{~mL})$ was added 3-(4-iodophenyl)-6methyl-1,2,4,5-tetrazine (2) (6.5 mg, $22 \mu \mathrm{mol}, 1.1 \mathrm{eq})$. The solution was stirred for 5 hours under inert gas. The crude product was concentrated under reduced pressure and directly purified on silica gel $\left(\mathrm{CHCl}_{3} / \mathrm{MeOH}\right)$ to give the desired compound as a white solid $(9.2 \mathrm{mg}, 60 \%) .{ }^{1} \mathrm{H}$ NMR $(400 \mathrm{MHz}$, $\left.\mathrm{CD}_{3} \mathrm{CN}\right): \delta 7.84(\mathrm{~d}, 2 \mathrm{H}, 8.4 \mathrm{~Hz}), 7.2(\mathrm{~d}, 2 \mathrm{H}, 8.4 \mathrm{~Hz}), 7.13-7.08$ (m, NH), 6.89-6.85 (m, NH), 6.85-6.76 (m, NH), 5.59-5.48 (m, NH), 4.28-4.22 (m, 1H, CH), 4.12-4.06 (q, 2H, 7.2 Hz), 4.06-3.99 (m, 1.3H), $3.81(\mathrm{~d}, 2 \mathrm{H}, 6 \mathrm{~Hz}), 3.71(\mathrm{~d}, 2.56 \mathrm{H}, 5.6 \mathrm{~Hz}), 3.05-2.95(\mathrm{~m}, 2 \mathrm{H}), 2.86-2.74(\mathrm{~m}, 2 \mathrm{H}), 2.67\left(\mathrm{~s}, 3 \mathrm{H}, \mathrm{CH}_{3}\right)$, 2.58-2.45 (m, 0.62H, $\mathrm{CH}_{2 \text { exo }}$ ), 2.34-2.18 (m, 2.34H, $\mathrm{CH}_{2 \text { endo }}$ ), 1.92-1.85 (m + s, $\left.5 \mathrm{H}, \mathrm{CH}_{3}+2 \mathrm{CH}\right), 1.81$ $1.73(\mathrm{~m}, 1 \mathrm{H}), 1.63-1.52(\mathrm{~m}, 2 \mathrm{H}), 1.45-1.26(\mathrm{~m}, 5 \mathrm{H}), 1.18$ (t, 3H, $\left.\mathrm{CH}_{3}, 6.8 \mathrm{~Hz}\right), 1.10-0.99(\mathrm{~m}, 0.68 \mathrm{H}$, $\mathrm{CH}_{2 \text { exo }}$ ), 0.90-0.79 (m, 1.35H, $\mathrm{CH}_{2 \text { endo }}$ ), 0.75-0.66 (M, $\left.1 \mathrm{H}\right) /{ }^{13} \mathrm{C} \mathrm{NMR}\left(100 \mathrm{MHz}, \mathrm{CD}_{3} \mathrm{CN}\right): \delta 173.0$, $171.5,170.7,170.4,158.9,141.8,139.5,138.3,94.6,92.5,62.48,61.8,53.9,44.0,41.9,41.1,32.1$, $30.4,30.1,28.5,28.4,28.3,23.3,23.0,20.9,20.8,14.5$ / HRMS: calculated for $\mathrm{C}_{34} \mathrm{H}_{45} \mathrm{IN}_{6} \mathrm{O}_{7} \mathrm{M}(+)$ : 777.2473 , found : $777.2479 / \mathrm{t}_{\mathrm{R}}: 6.8 \mathrm{~min}$. 


\section{2) Determination of partition coefficients $(\log P)$}

The partition coefficients of $\mathbf{1 a}$ and $\mathbf{1 b}$ were measured according to the method described by Ogawa $\mathrm{K}$ et al..$^{2}$ Namely, $\mathbf{1 a}$ or $\mathbf{1 b}$ were mixed with $3 \mathrm{~mL}$ each of 1-octanol and phosphate buffer $(0.02 \mathrm{M}, \mathrm{pH} 7.4)$ in a test tube. The mixture was vortexed for $10 \mathrm{~min}$. The mixture was then centrifuged at $1000 \mathrm{~g}$ for $5 \mathrm{~min} .2 .5 \mathrm{~mL}$ of 1 -octanol was removed and added to $2.5 \mathrm{~mL}$ of new phosphate buffer $(0.02 \mathrm{M}, \mathrm{pH} 7.4)$. After repeating the same procedure twice, $100 \mu \mathrm{L}$ and $1 \mathrm{~mL}$ of 1-octanol and phosphate buffer were withdrawn and their radioactivity and weight were measured. The partition coefficients were determined by calculating the ratio of $\mathrm{cpm} / \mathrm{mL}$ in 1-octanol to that in the buffer, and expressed as a common logarithm (log P). Each $\log \mathrm{P}$ determination was performed in triplicate.

\section{References}

1. Dommerholt J, Schmidt S, Temming R, et al. Readily Accessible Bicyclononynes for Bioorthogonal Labeling and Three-Dimensional Imaging of Living Cells. Angew Chem Int Ed. 2010;49(49):9422-9425. doi:10.1002/anie.201003761

2. Ogawa K, Shiba K, Akhter N, et al. Evaluation of radioiodinated vesamicol analogs for sigma receptor imaging in tumor and radionuclide receptor therapy. Cancer Science. 2009;100(11):2188-2192. doi:10.1111/j.1349-7006.2009.01279.x

\section{3) RETENTION TIME TABLE AND UV-HPLC CHROMATOGRAMS}

\section{OF REFERENCE COMPOUNDS}

\begin{tabular}{|c|c|}
\hline Compound & $\mathbf{t}_{\mathrm{R}}(\mathrm{min})$ \\
\hline 1 & 8.3 \\
2 & 8.6 \\
\hline 14 & 2.1 \\
15 & 4.0 \\
16 & 5.3 \\
17 & 3.5 \\
\hline 18 & 4.1 \\
19 & $6.3+7.6+8.2$
\end{tabular}



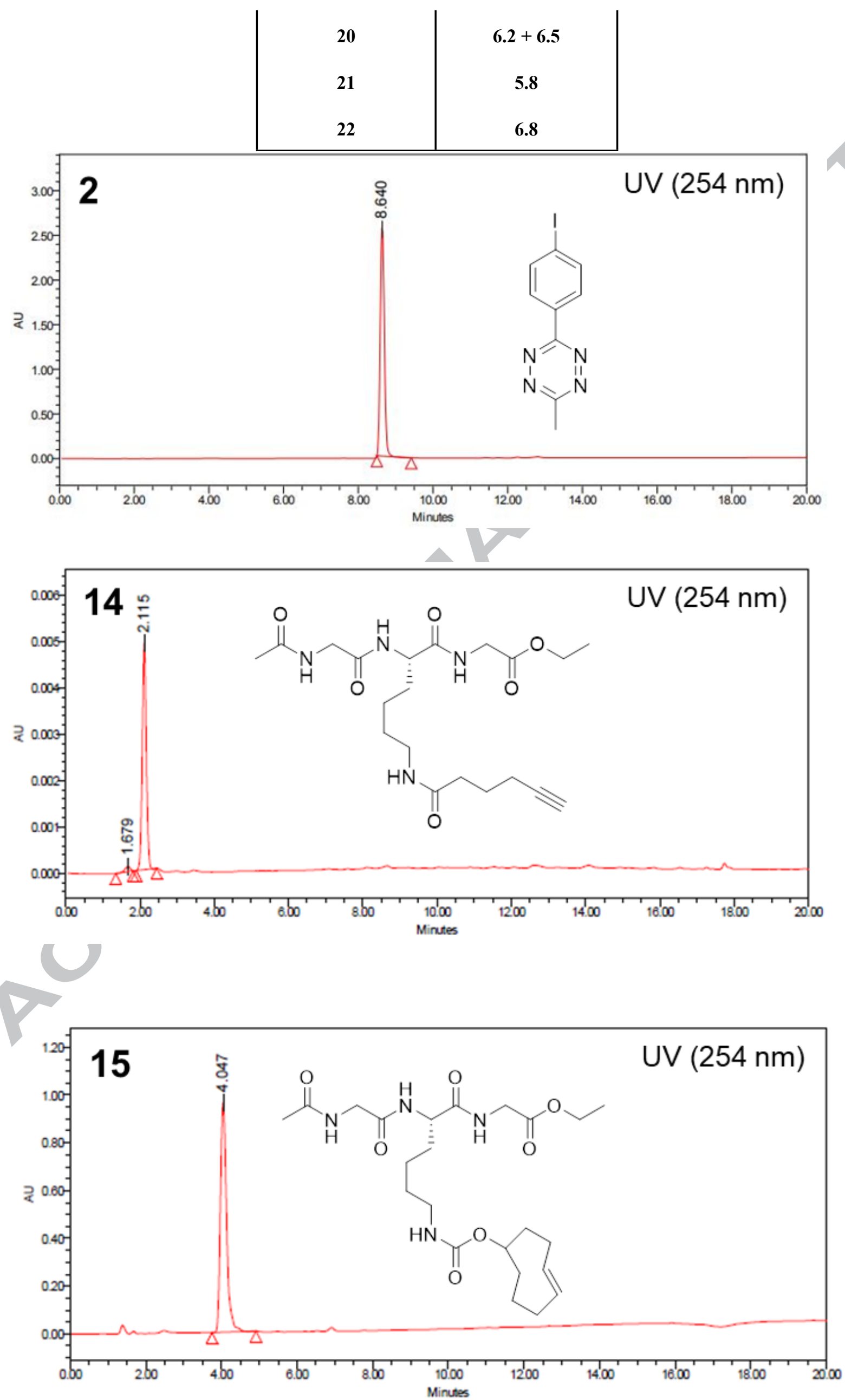

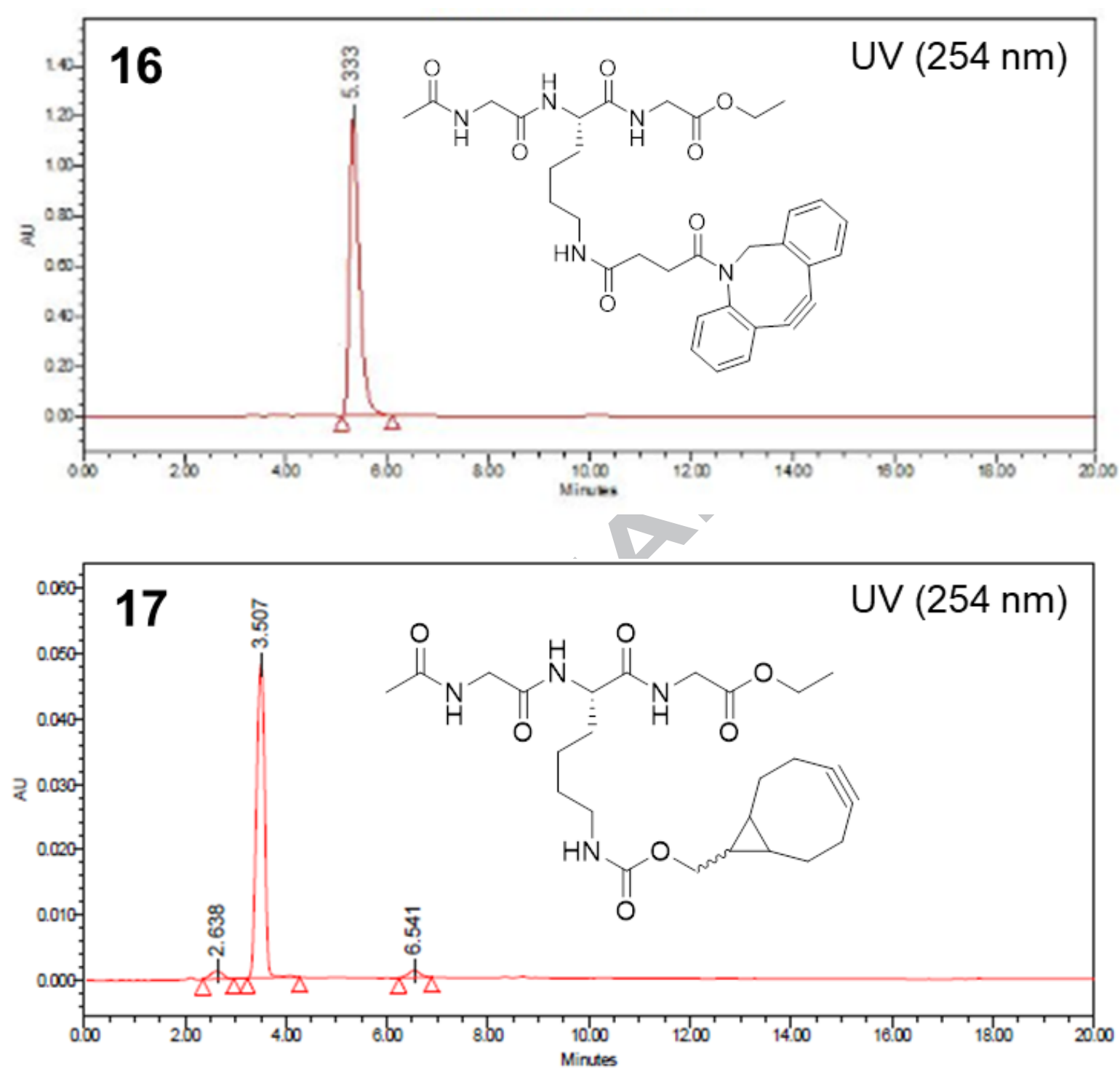

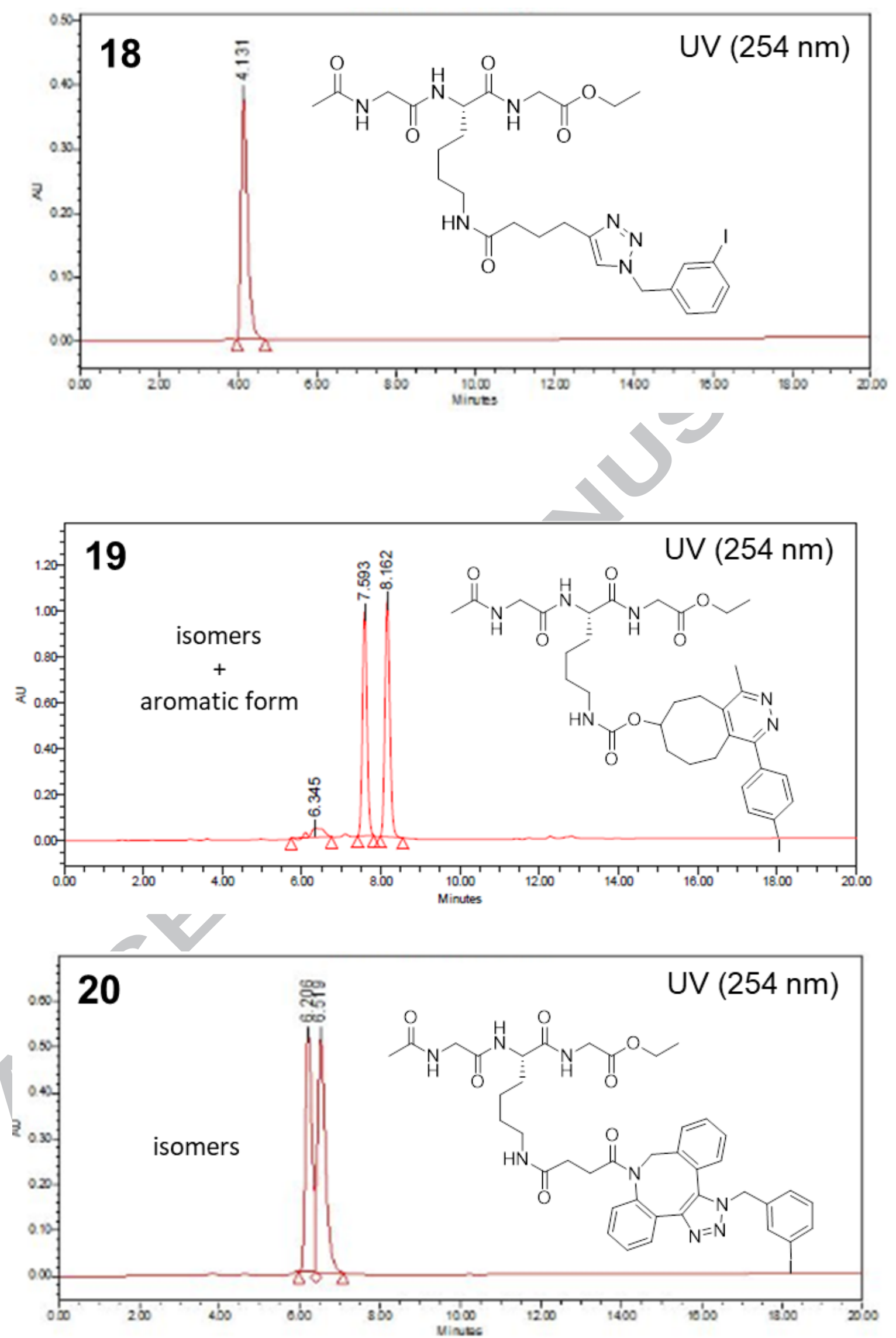

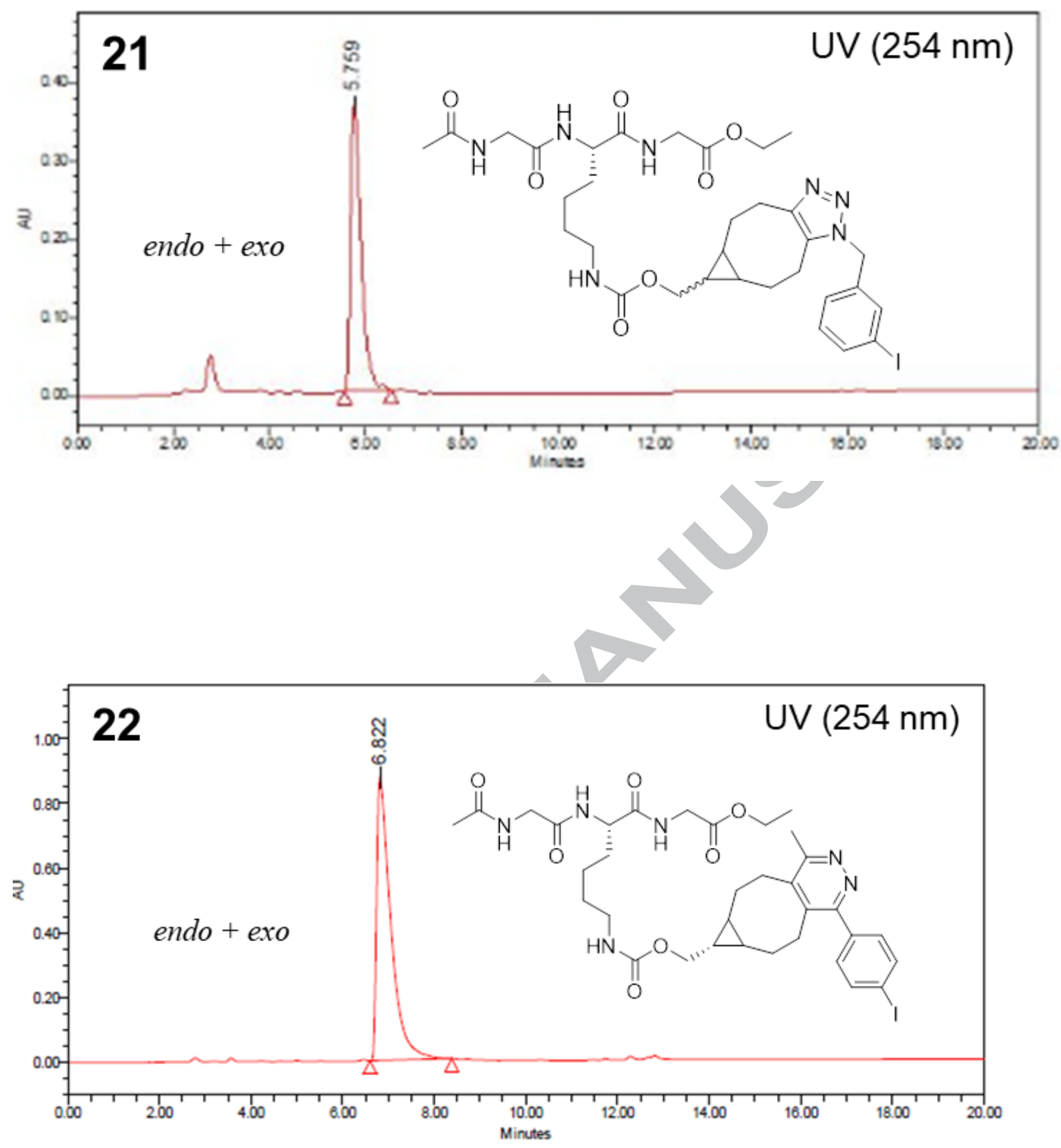


\section{4) Radiochromatograms}

Radiolabeling (3) lodine-125 $\left(120^{\circ} \mathrm{C}\right.$ - $30 \mathrm{~min}$ - ACN $)$
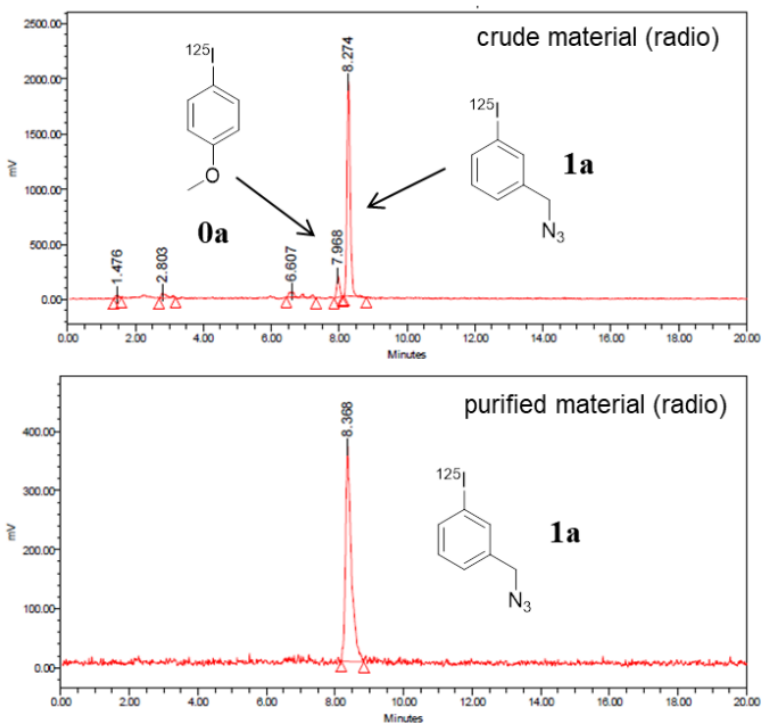

Radiolabeling (4) lodine-125 $\left(100^{\circ} \mathrm{C}-30 \mathrm{~min}-\mathrm{ACN}\right)$
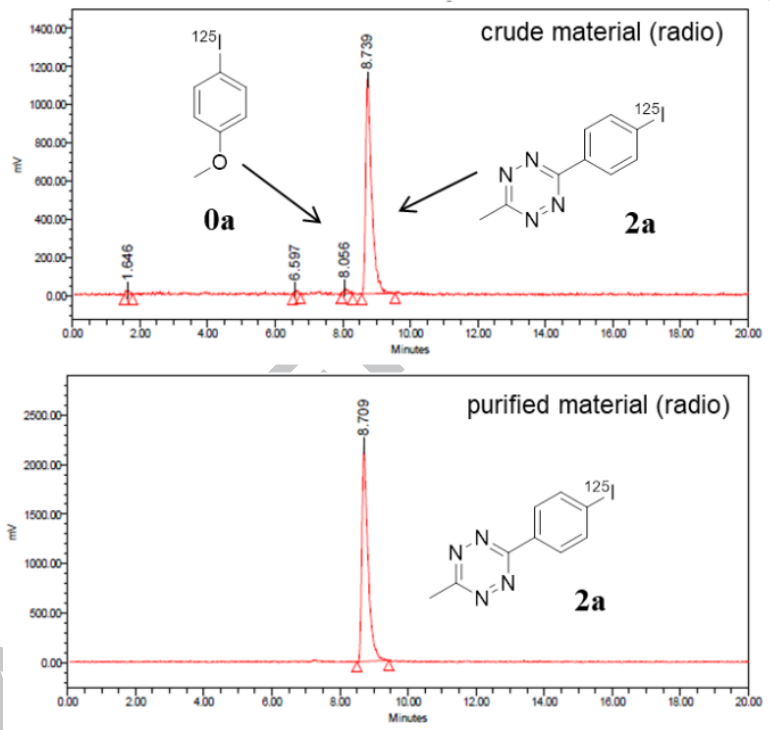

Radiolabeling (3)

Astatine-211 $\left(80^{\circ} \mathrm{C}-30 \mathrm{~min}-\mathrm{MeOH}\right)$
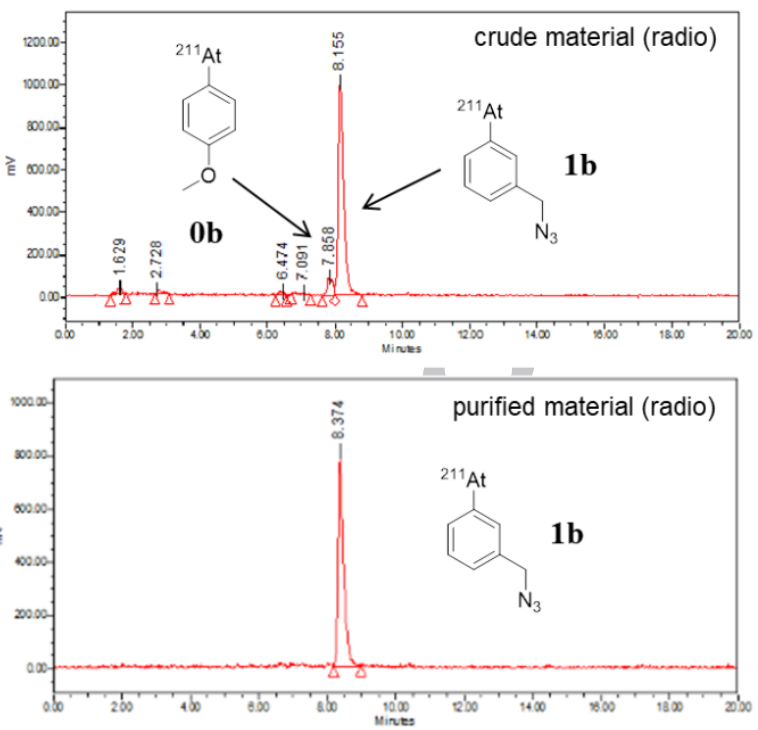

Radiolabeling (4)

Astatine-211 $\left(60^{\circ} \mathrm{C}-30 \mathrm{~min}-\mathrm{MeOH}\right)$
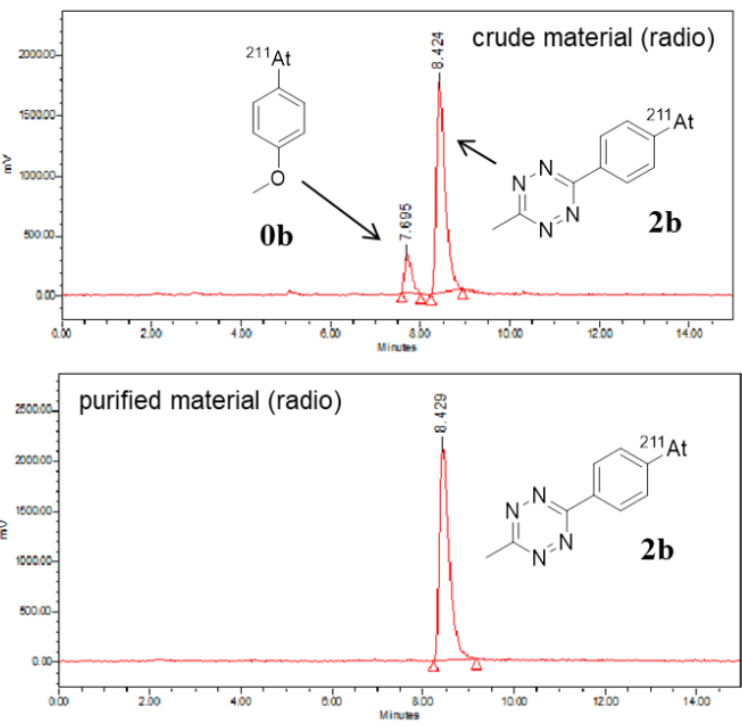

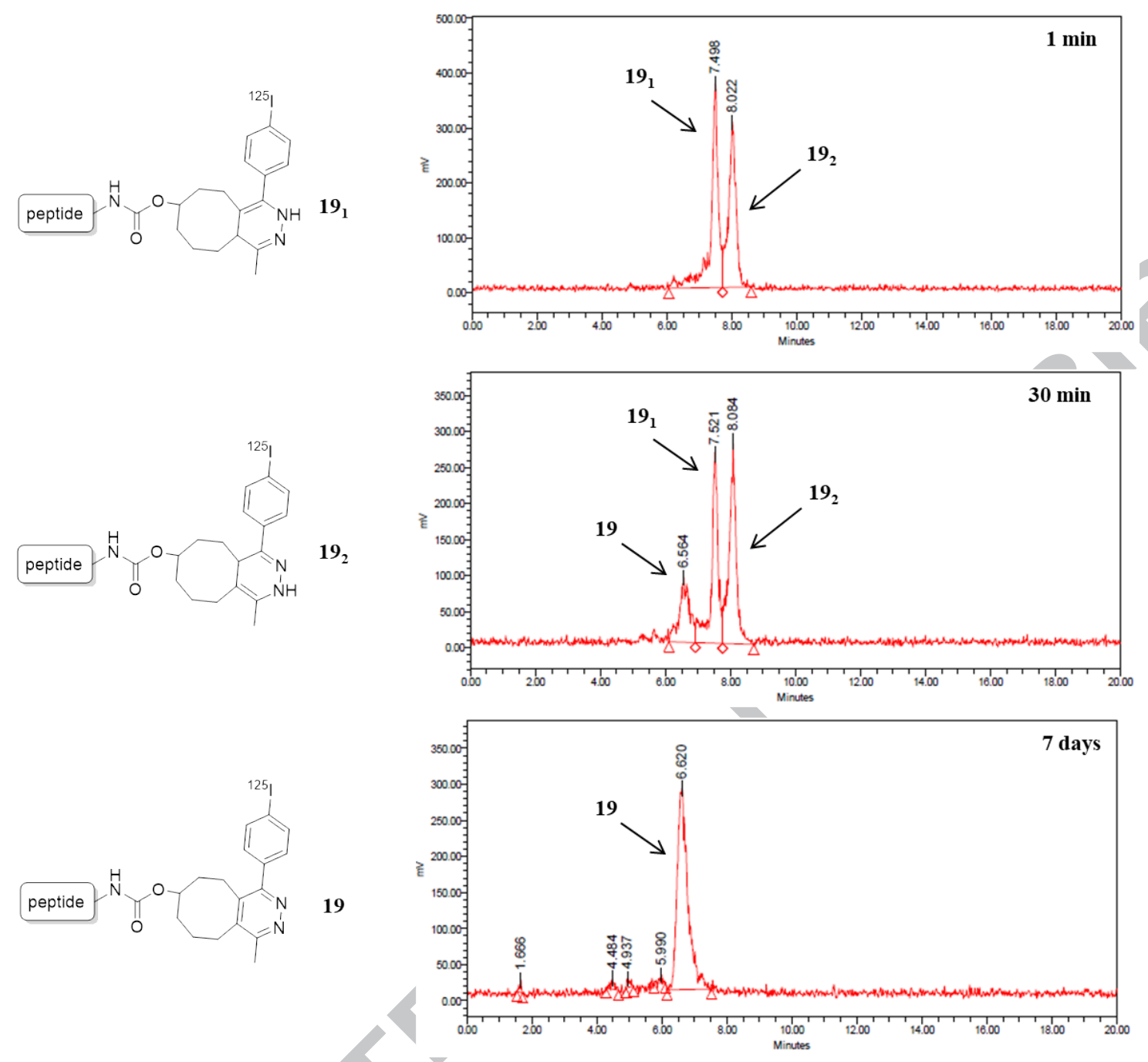


\section{5) NMR SPECTRA + HRMS}

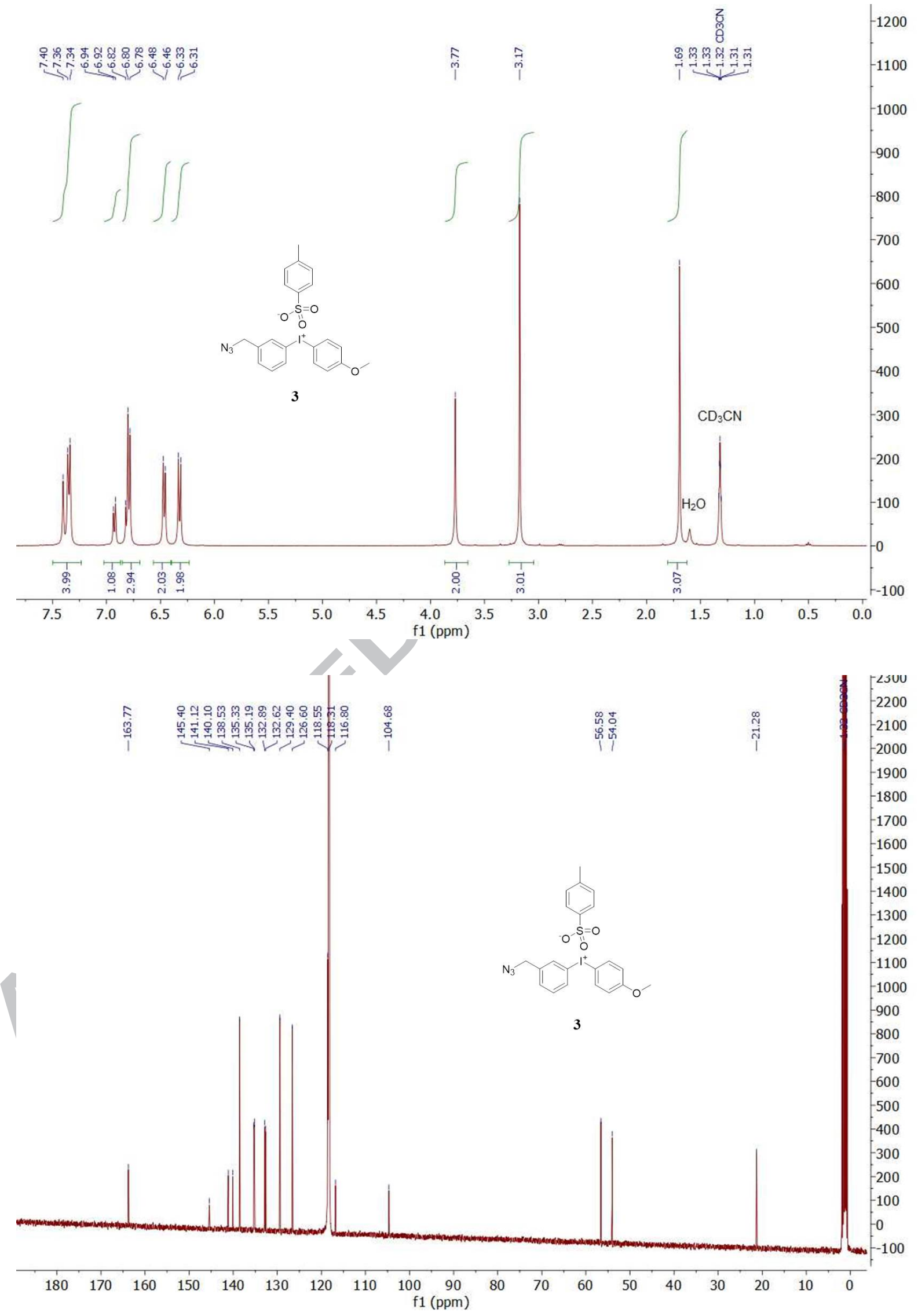




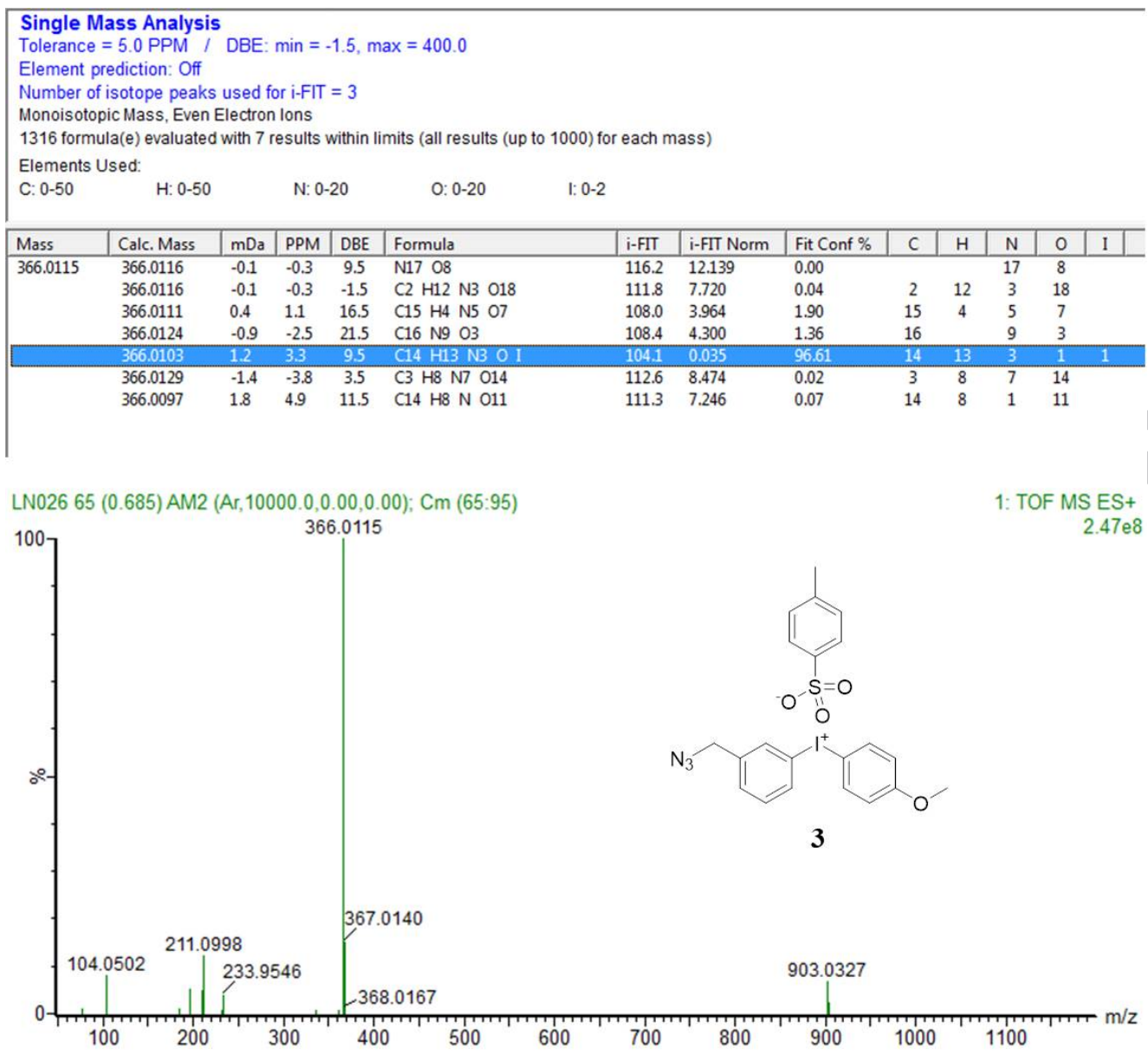




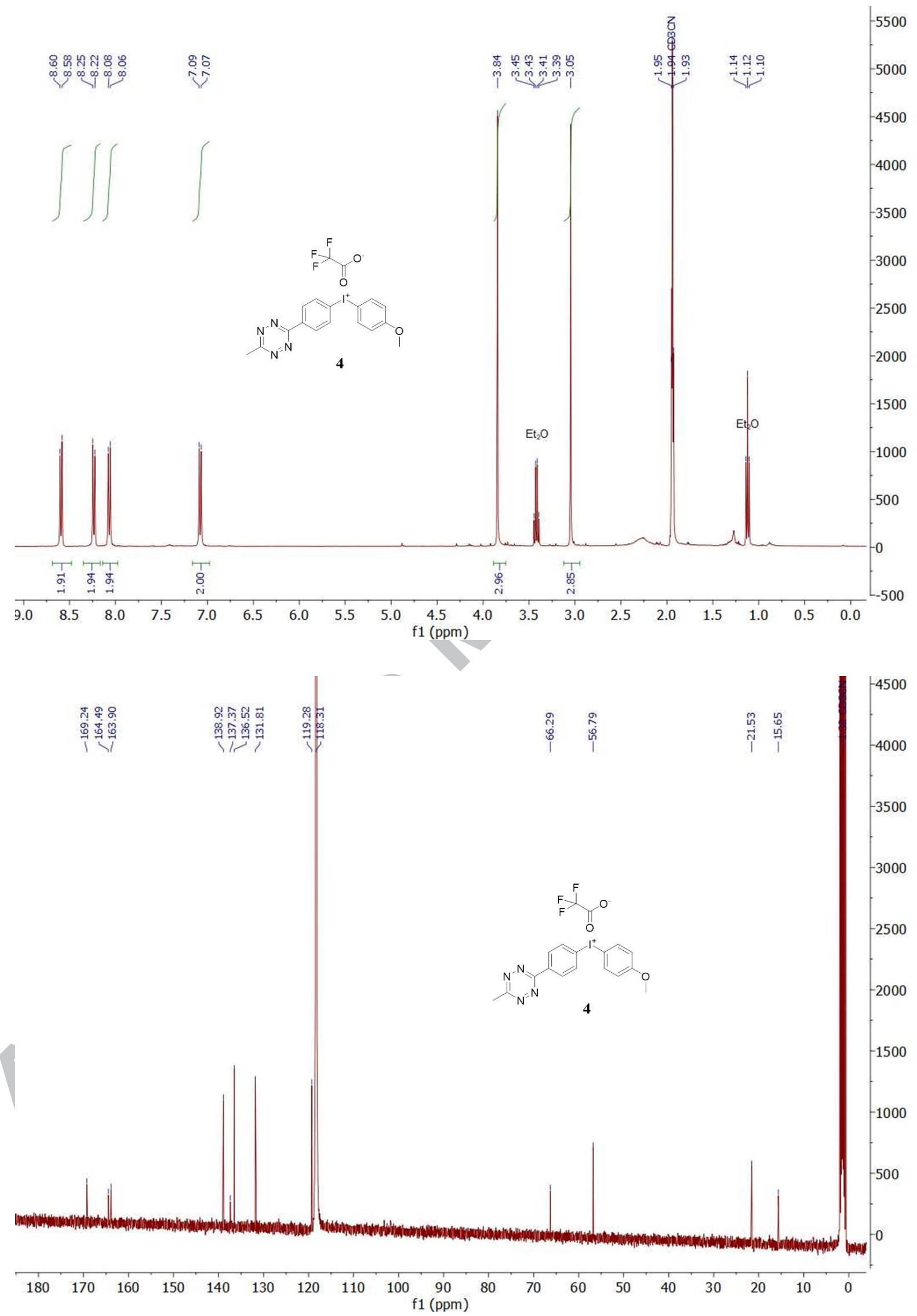



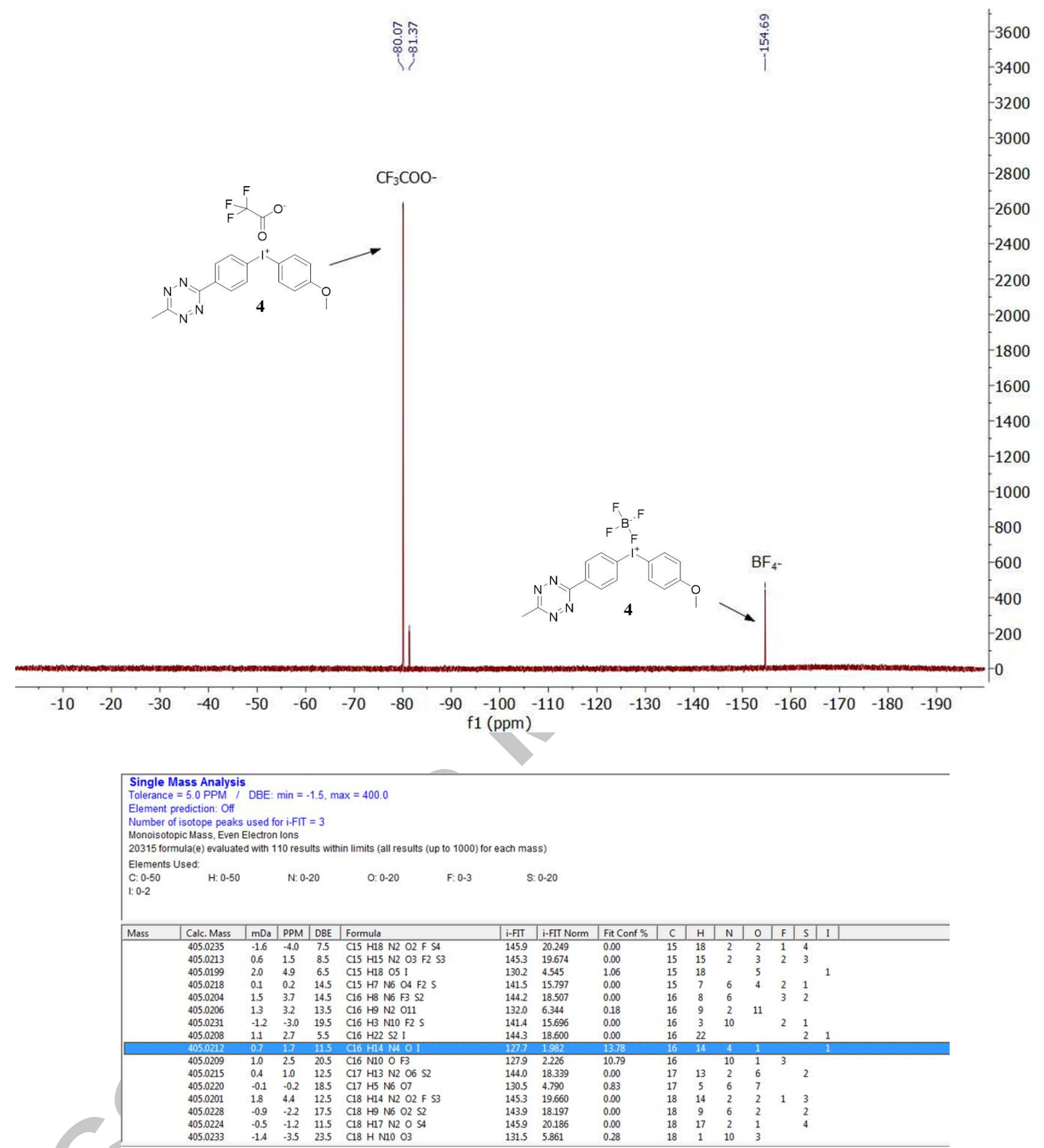

LN141 73 (0.766) AM2 (Ar, 10000.0,0.00,0.00); Cm (62:76)

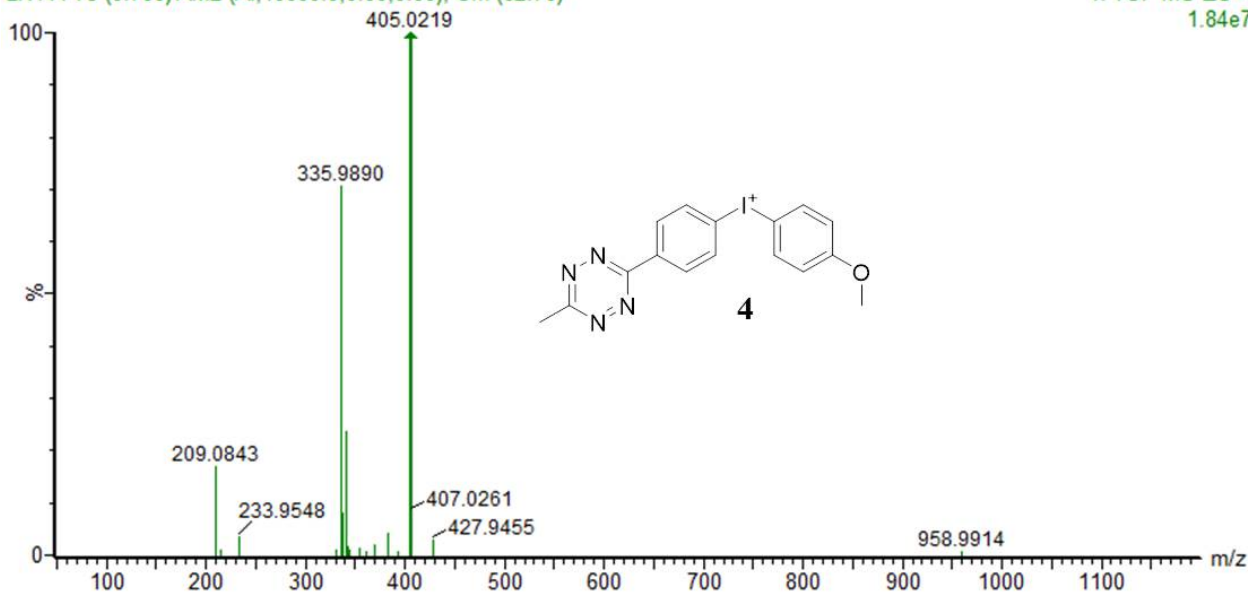



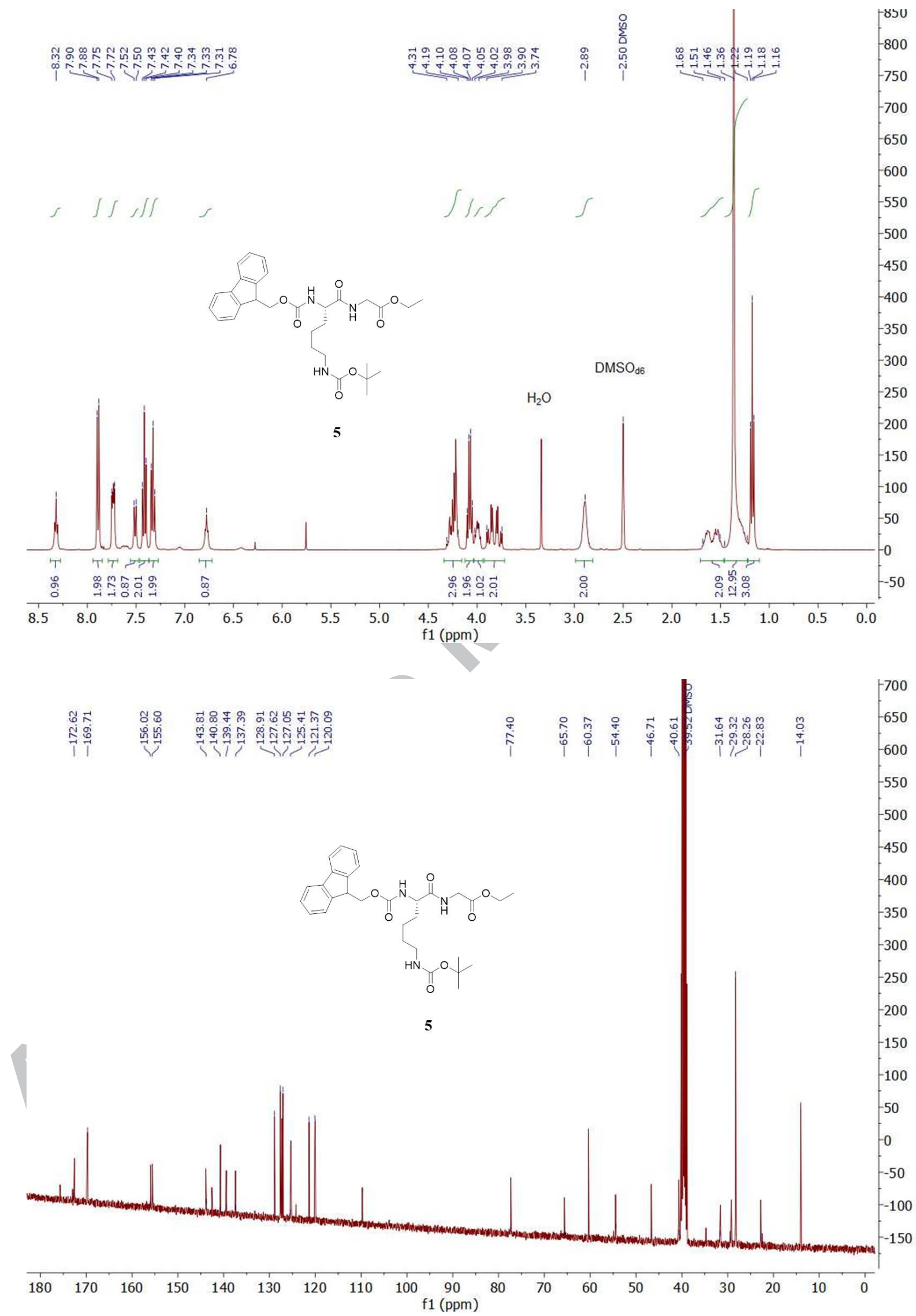
ACCEPTED MANUSCRIPT
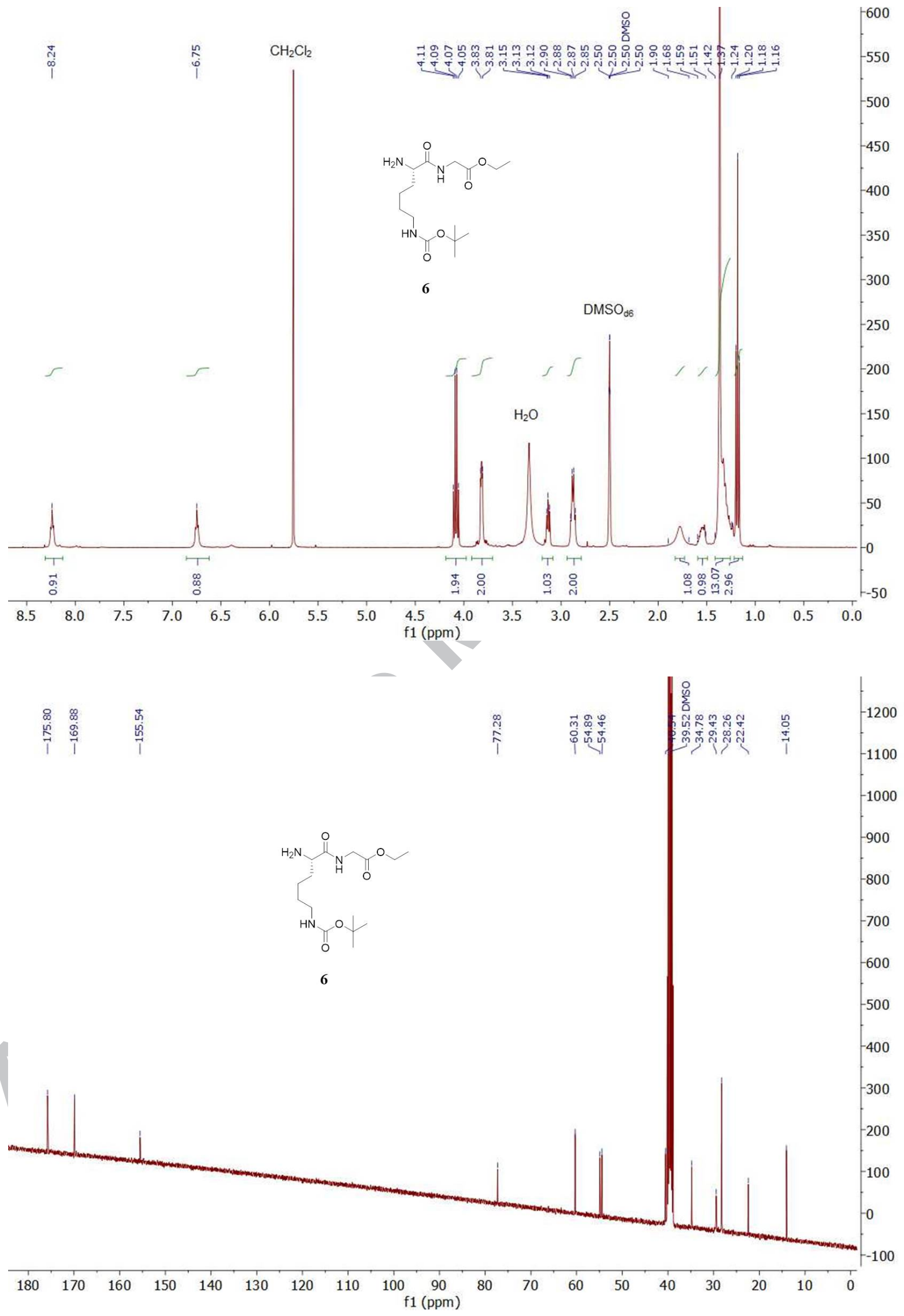

S23 


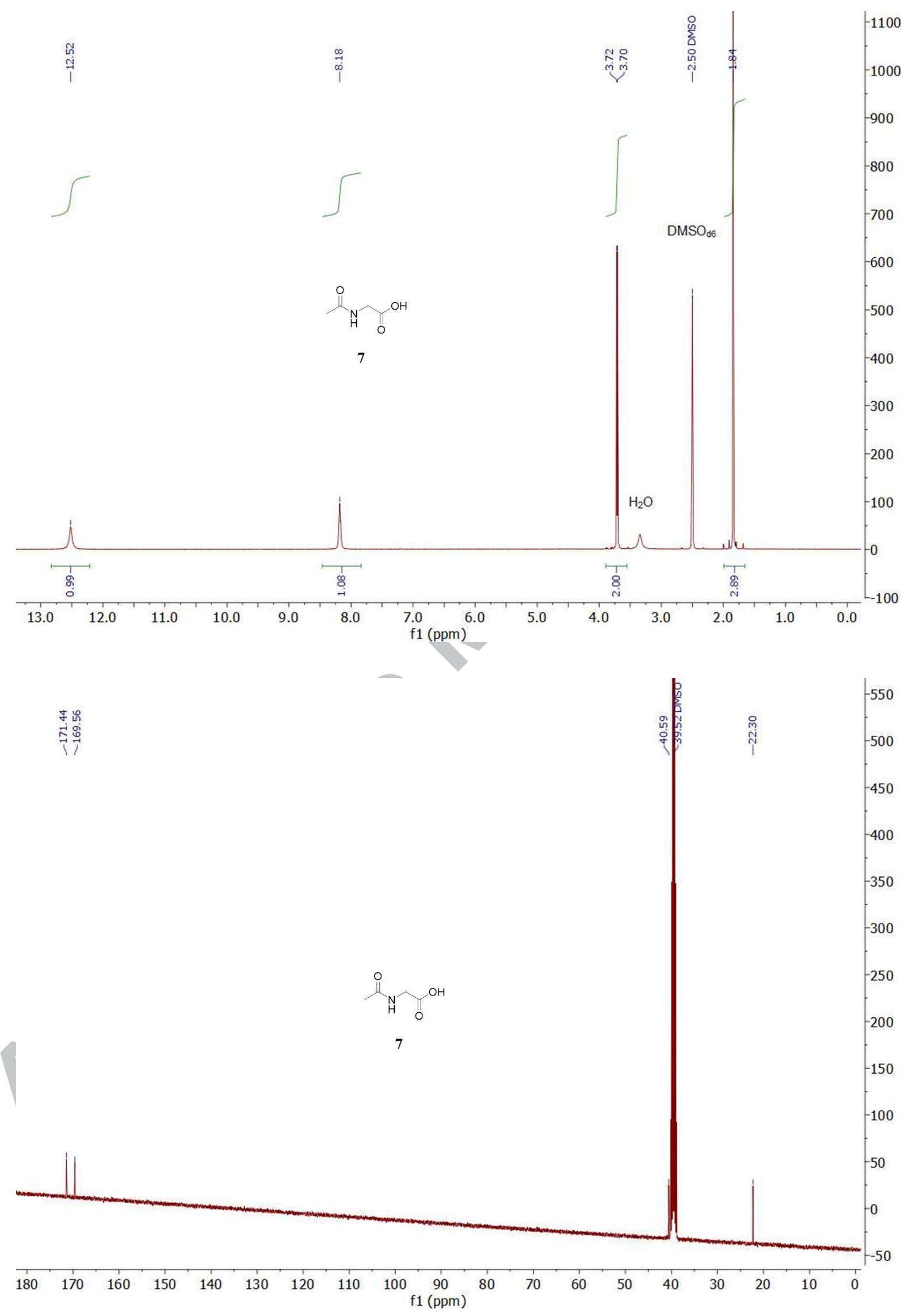



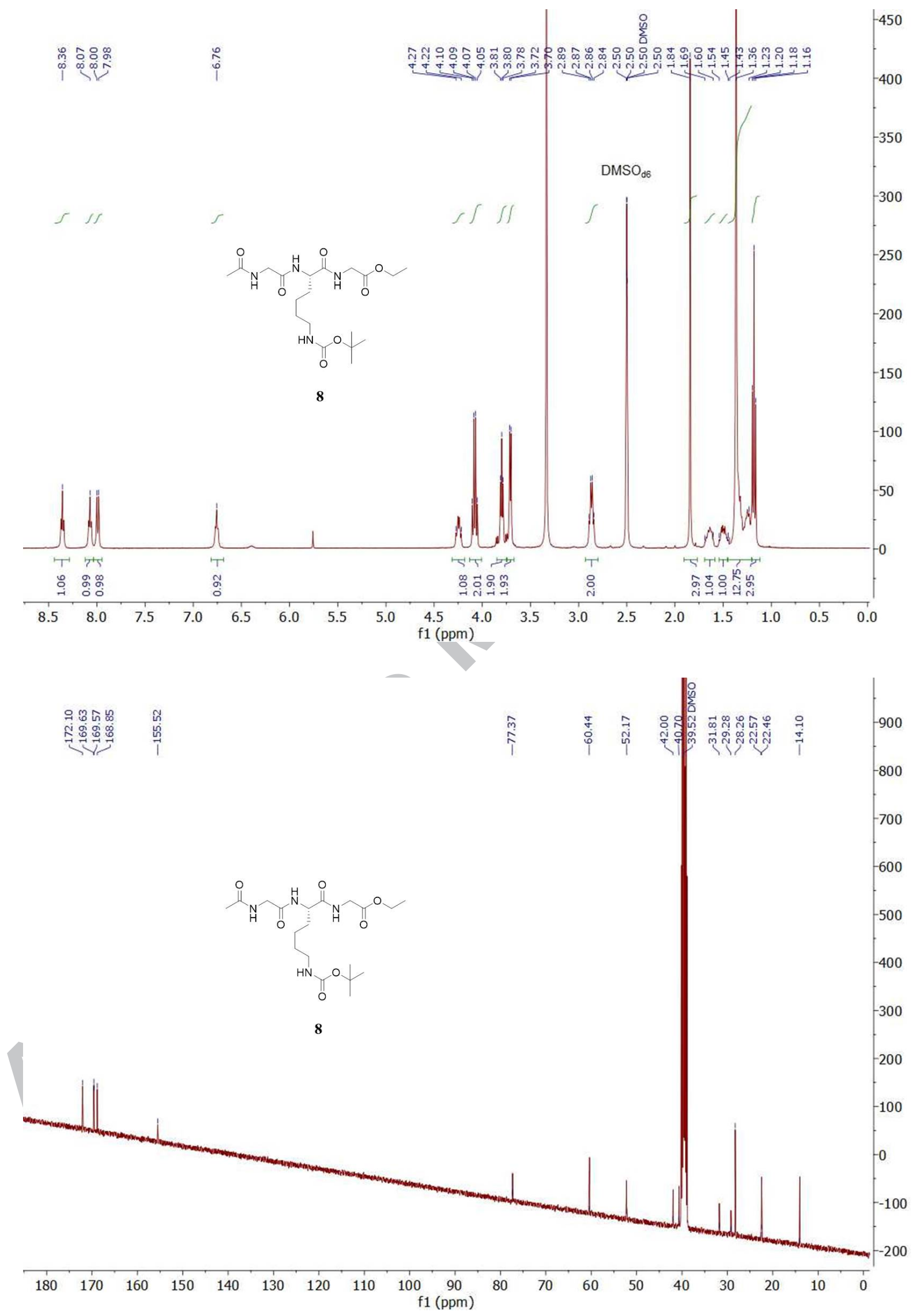

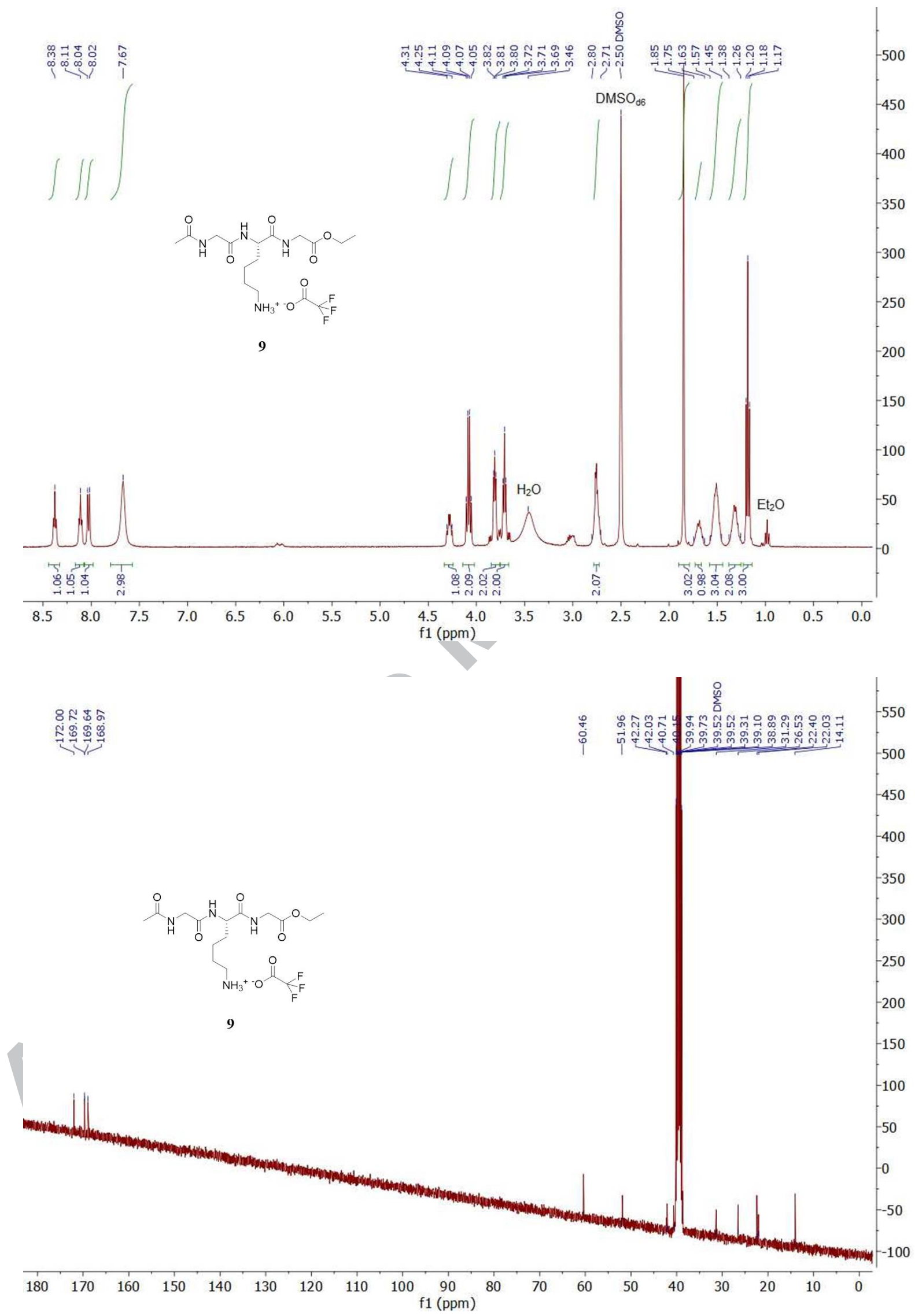


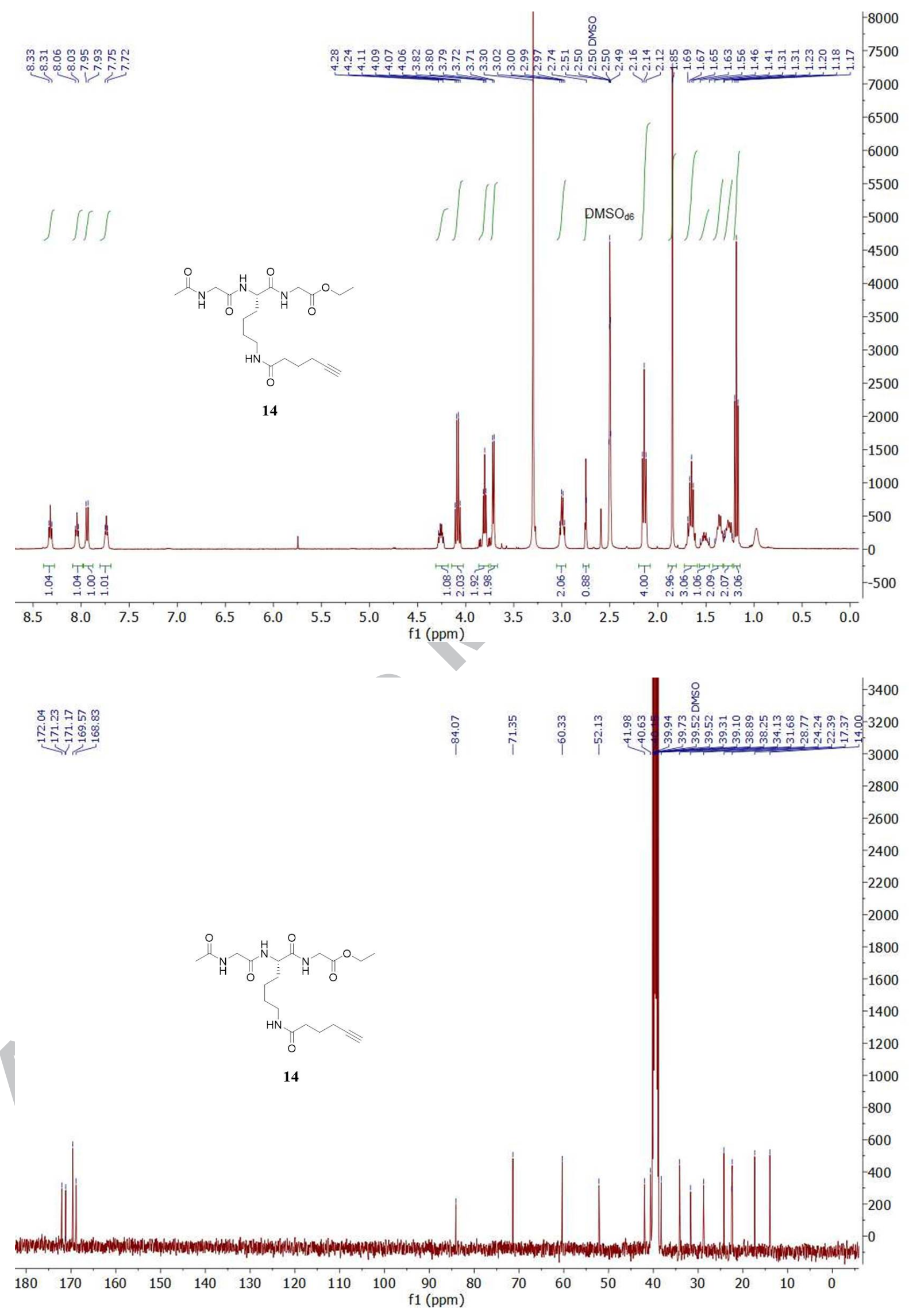




\section{Single Mass Analysis}

Tolerance $=5.0$ PPM / DBE: $\min =-1.5, \max =400.0$

Element prediction: Off

Number of isotope peaks used for i-FIT $=3$

Monoisotopic Mass, Even Electron Ions

2529 formula(e) evaluated with 10 results within limits (all results (up to 1000) for each mass)

Elements Used:

$\begin{array}{lllll}\text { C: } 0-50 & \mathrm{H}: 0-50 & \mathrm{~N}: 0-20 & \mathrm{O}: 0-20 & \mathrm{Na}: 0-1\end{array}$

\begin{tabular}{|c|c|c|c|c|c|c|c|c|c|c|c|c|c|}
\hline Mass & Calc. Mass & $\mathrm{mDa}$ & PPM & DBE & Formula & i-FIT & i-FIT Norm & Fit Conf $\%$ & $C$ & $\mathrm{H}$ & $\mathrm{N}$ & 0 & $\mathrm{Na}$ \\
\hline & 447.2190 & 1.2 & 2.7 & 0.5 & $\mathrm{C} 16$ H35 N2 012 & 94.7 & 6.736 & 0.12 & 16 & 35 & 2 & 12 & \\
\hline & 447.2206 & -0.4 & -0.9 & 12.5 & $\mathrm{C} 17 \mathrm{H}_{24} \mathrm{~N} 14 \mathrm{Na}$ & 91.0 & 2.980 & 5.08 & 17 & 24 & 14 & & 1 \\
\hline & 447.2203 & -0.1 & -0.2 & 5.5 & $\mathrm{C} 17 \mathrm{H} 31 \mathrm{~N} 6 \mathrm{O} 8$ & 91.8 & 3.772 & 2.30 & 17 & 31 & 6 & 8 & \\
\hline & 447.2217 & -1.5 & -3.4 & 10.5 & $\mathrm{C} 18 \mathrm{H} 27 \quad \mathrm{~N} 10 \mathrm{O} 4$ & 91.2 & 3.208 & 4.04 & 18 & 27 & 10 & 4 & \\
\hline & 447.2206 & -0.4 & -0.9 & 1.5 & $\mathrm{C} 19 \mathrm{H} 36 \mathrm{O} 10 \mathrm{Na}$ & 94.4 & 6.354 & 0.17 & 19 & 36 & & 10 & 1 \\
\hline & 447.2220 & -1.8 & -4.0 & 6.5 & $\mathrm{C} 20 \mathrm{H} 32 \mathrm{~N} 4 \mathrm{O} 6 \mathrm{Na}$ & 94.1 & 6.131 & 0.22 & 20 & 32 & 4 & 6 & 1 \\
\hline & 447.2185 & 1.7 & 3.8 & 18.5 & $\mathrm{C} 29 \mathrm{H} 27 \mathrm{~N} 4 \mathrm{O}$ & 100.4 & 12.420 & 0.00 & 29 & 27 & 4 & 1 & \\
\hline
\end{tabular}

LN129 49 (0.523) AM2 (Ar, 10000.0,0.00,0.00); Cm (41:56)

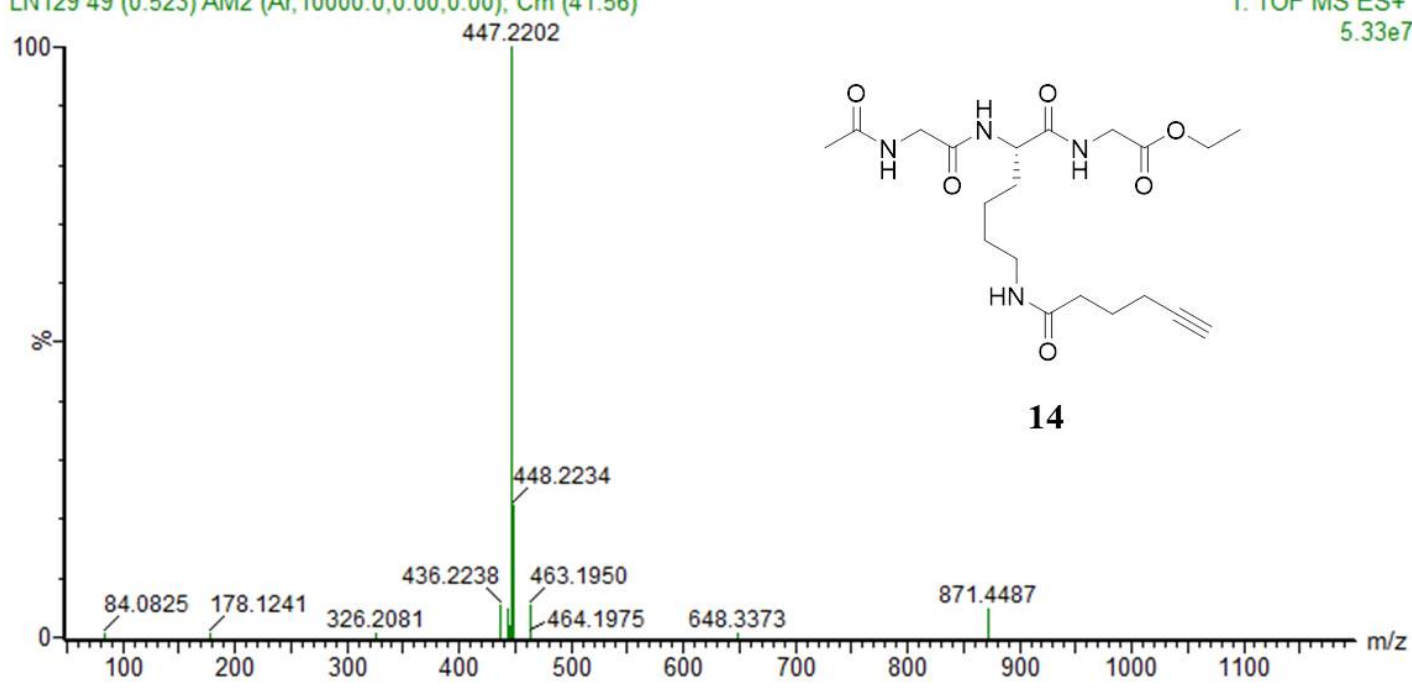



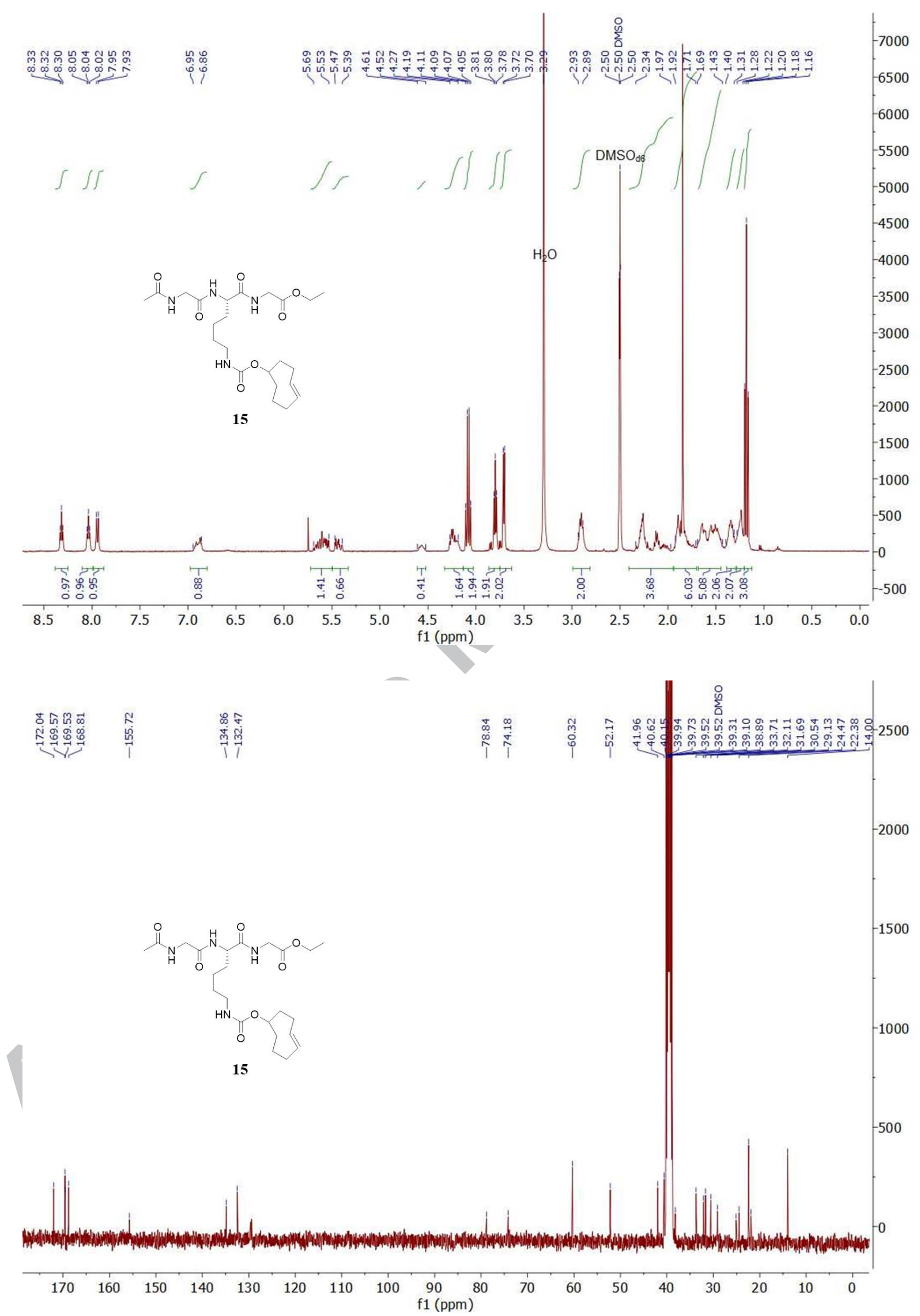


\begin{tabular}{|c|c|c|c|c|c|c|c|c|c|c|c|c|c|}
\hline \multicolumn{14}{|c|}{$\begin{array}{l}\text { Single Mass Analysis } \\
\text { Tolerance }=5.0 \text { PPM / DBE: } \min =-1.5, \max =400.0 \\
\text { Element prediction: Off } \\
\text { Number of isotope peaks used for i-FIT }=3 \\
\text { Monoisotopic Mass, Even Electron lons } \\
3033 \text { formula(e) evaluated with } 14 \text { results within limits (all results (up to 1000) for each mass) } \\
\text { Elements Used: }\end{array}$} \\
\hline Mass & Calc. Mass & $\mathrm{mDa}$ & PPM & DBE & Formula & i-FIT & i-FTT Norm & Fit Conf \% & $\mathrm{c}$ & $\mathrm{H}$ & $\mathrm{N}$ & 0 & $\mathrm{Na}$ \\
\hline \multirow{13}{*}{505.2656} & 505.2643 & 1.3 & 2.6 & -0.5 & $\mathrm{C} 8 \mathrm{H} 34 \mathrm{~N} 1608 \mathrm{Na}$ & 41.4 & 4.360 & 1.28 & 8 & 34 & 16 & 8 & 1 \\
\hline & 505.2657 & -0.1 & -0.2 & 4.5 & $\mathrm{Cg} \mathrm{H} 30 \mathrm{~N} 20 \quad 04 \mathrm{Na}$ & 40.0 & 2.936 & 5.31 & 9 & 30 & 20 & 4 & 1 \\
\hline & 505.2667 & -1.1 & -2.2 & 2.5 & $\mathrm{C} 10 \mathrm{H} 33 \mathrm{~N} 16 \mathrm{O} 8$ & 39.6 & 2.514 & 8.09 & 10 & 33 & 16 & 8 & \\
\hline & 505.2681 & -2.5 & -4.9 & 7.5 & $\mathrm{C} 11 \mathrm{H}_{22} \mathrm{~N} 20 \mathrm{O}$ & 39.4 & 2.315 & 9.88 & 11 & 29 & 20 & 4 & \\
\hline & 505.2670 & -1.4 & -2.8 & -1.5 & $\mathrm{C} 12 \mathrm{H} 38 \mathrm{~N} 10 \mathrm{O} 10 \mathrm{Na}$ & 38.6 & 1.507 & 22.15 & 12 & 38 & 10 & 10 & 1 \\
\hline & 505.2635 & 2.1 .4 & 4.2 & 10.5 & $\mathrm{C} 21 \mathrm{H} 33 \mathrm{~N} 1005$ & 40.7 & 3.619 & 2.68 & 21 & 33 & 10 & 5 & \\
\hline & 505.2649 & 0.7 & 1.4 & 15.5 & $\mathrm{C} 22 \mathrm{H} 29 \mathrm{~N} 140$ & 39.2 & 2.161 & 11.52 & 22 & 29 & 14 & 1 & \\
\hline & 505.2638 & 1.8 & 3.6 & 6.5 & $\mathrm{C} 23 \mathrm{H} 38 \mathrm{N4} 07 \mathrm{Na}$ & 40.2 & 3.083 & 4.58 & 23 & 38 & 4 & $\frac{1}{7}$ & 1 \\
\hline & 505.2652 & 0.4 & 0.8 & 11.5 & $\mathrm{C} 24 \mathrm{H} 34 \mathrm{~N} 8 \mathrm{O} 3 \mathrm{Na}$ & 38.6 & 1.480 & 22.77 & 24 & 34 & 8 & 3 & 1 \\
\hline & 505.2649 & 0.7 & 1.4 & 4.5 & $\mathrm{C} 24 \mathrm{H} 41 \mathrm{O} 011$ & 40.0 & 2.936 & 5.31 & 24 & 41 & & 11 & \\
\hline & 505.2662 & -0.6 & -1.2 & 9.5 & $\mathrm{C} 25 \mathrm{H} 37 \mathrm{~N} 4 \mathrm{O} 07$ & 40.0 & 2.966 & 5.15 & 25 & 37 & 4 & 7 & \\
\hline & 505.2676 & -2.0 & -4.0 & 14.5 & $\mathrm{C} 26 \mathrm{H} 33 \mathrm{~N} 8 \mathrm{O} 3$ & 41.7 & 4.659 & 0.95 & 26 & 33 & 8 & 3 & \\
\hline & 505.2678 & -2.2 & -4.4 & 10.5 & $\mathrm{C} 28 \mathrm{H} 38 \mathrm{~N} 2 \quad 05 \mathrm{Na}$ & 43.4 & 6.358 & 0.17 & 28 & 38 & 2 & 5 & 1 \\
\hline
\end{tabular}

LN130 33 (0.360) AM2 (Ar, 10000.0,0.00,0.00); Cm (33:67)

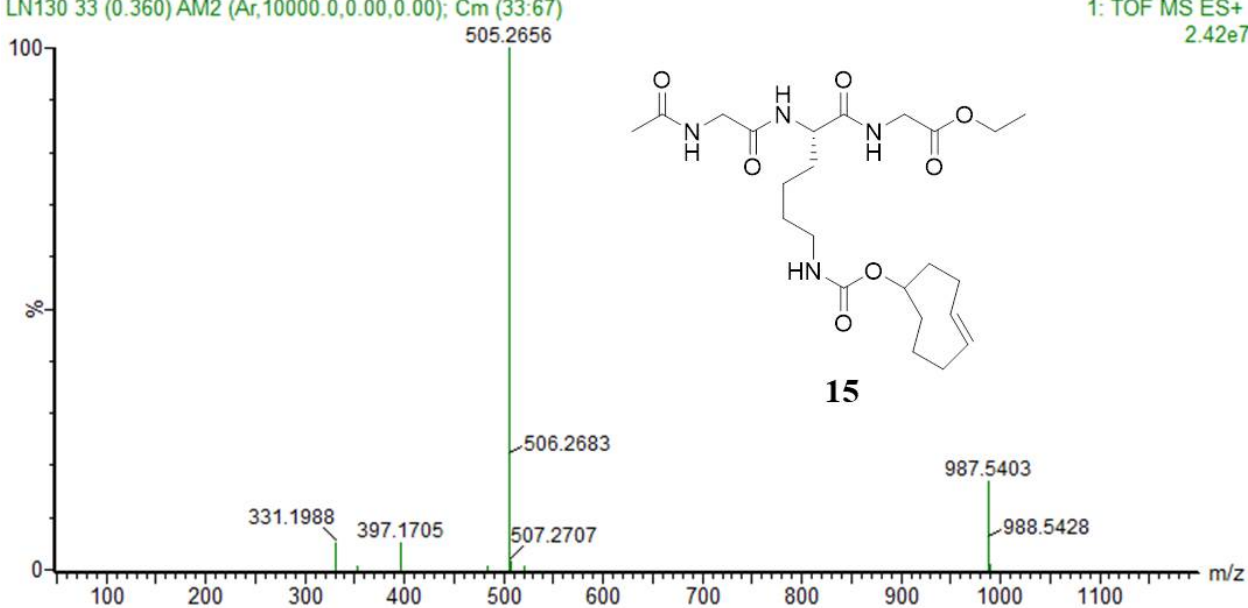




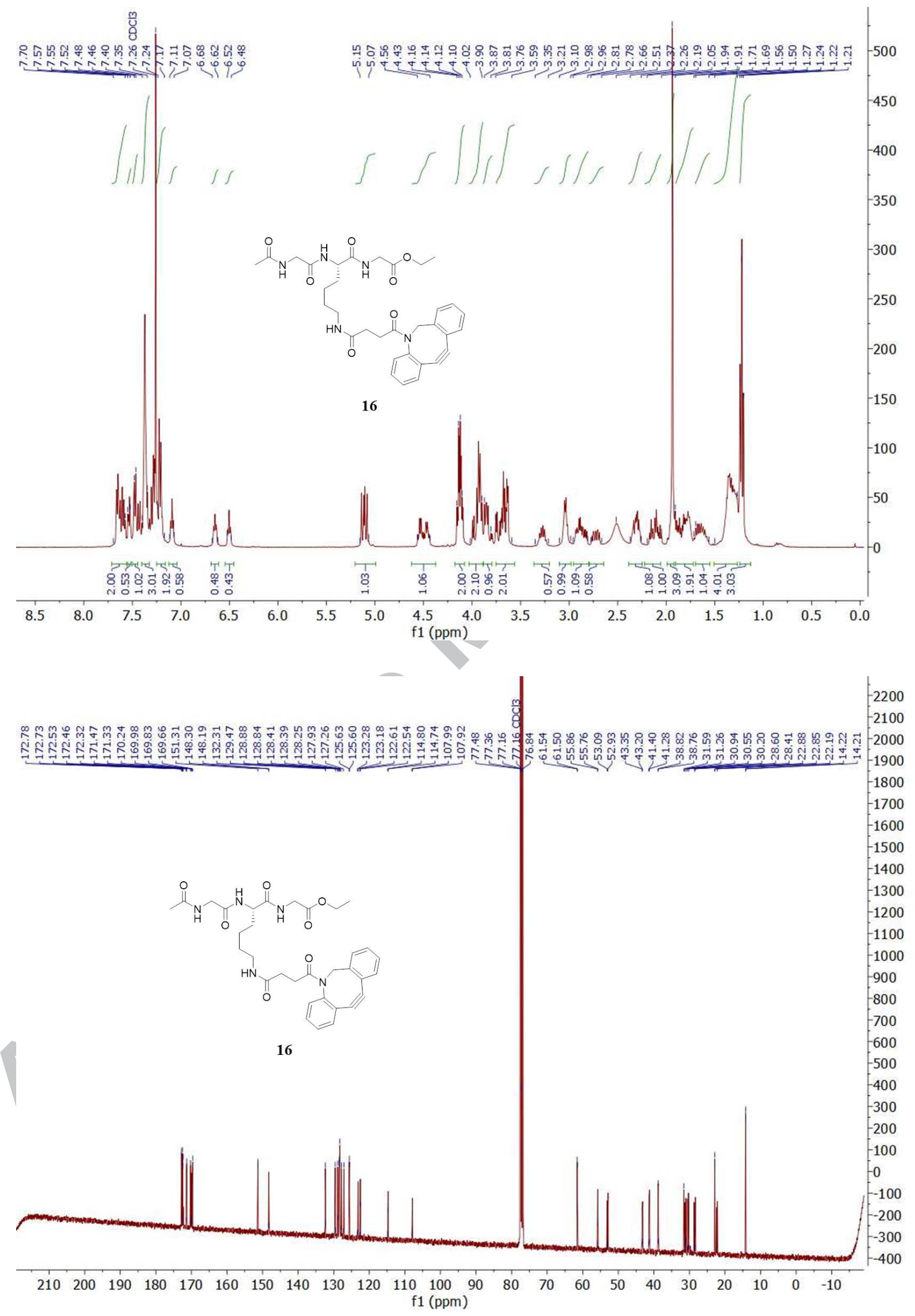




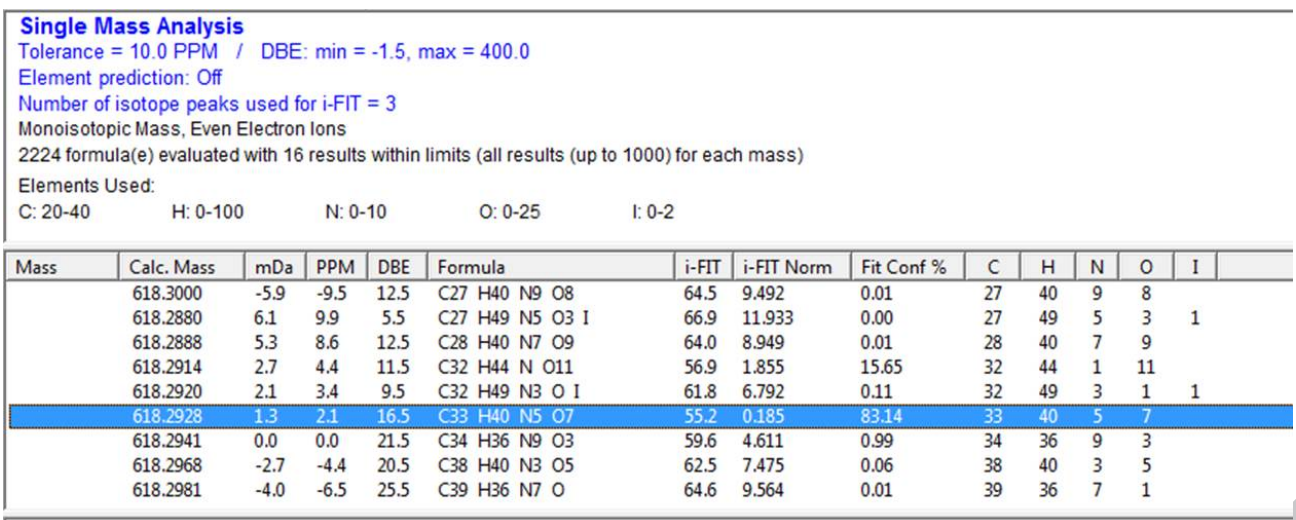

FG529 5 (0.050) AM2 (Ar,20000.0,0.00,0.00); Cm (5.29)

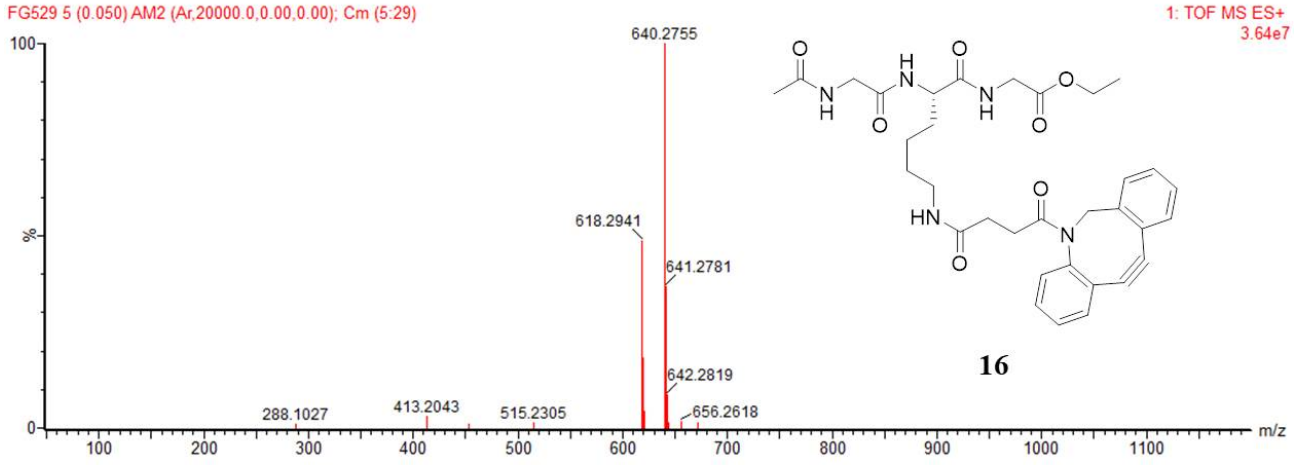



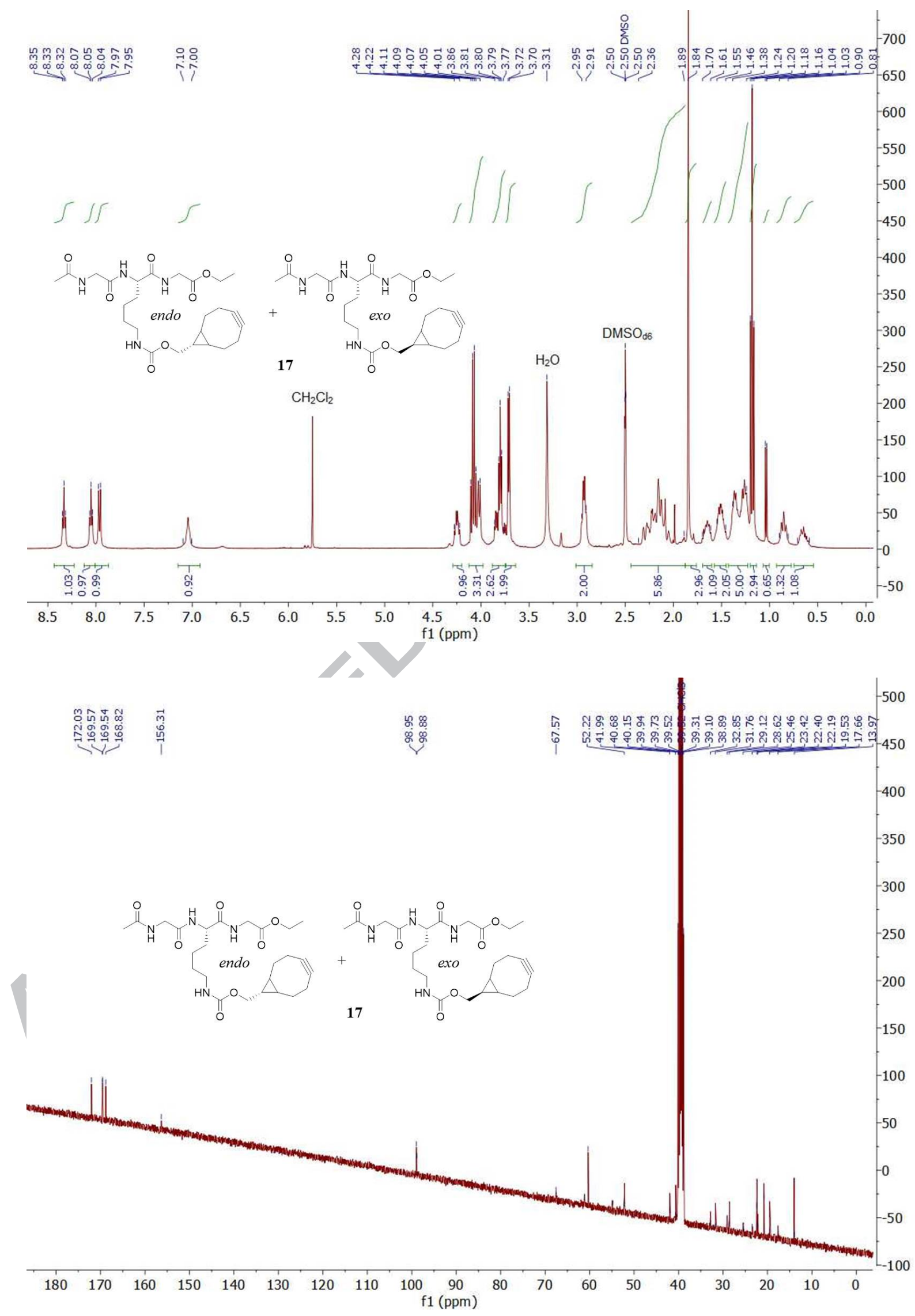
Single Mass Analysis

Tolerance $=5.0$ PPM / DBE: $\min =-1.5, \max =400.0$

Element prediction: Off

Number of isotope peaks used for $\mathrm{i}-\mathrm{FIT}=3$

Monoisotopic Mass, Even Electron Ions

3195 formula(e) evaluated with 17 results within limits (all results (up to 1000) for each mass)

Elements Used:

$\begin{array}{lllll}\text { C: } 0-50 & H: 0-50 & \text { N: } 0-20 & 0: 0-20 & \text { Na: } 0-1\end{array}$

\begin{tabular}{|c|c|c|c|c|c|c|c|c|c|c|c|c|c|}
\hline Mass & Calc. Mass & $\mathrm{mDa}$ & PPM & DBE & Formula & i-FTT & i-FIT Norm & Fit Conf \% & C & $\mathrm{H}$ & $\mathrm{N}$ & 0 & $\mathrm{Na}$ \\
\hline \multirow[t]{14}{*}{529.2644} & 529.2627 & 1.7 & 3.2 & 0.5 & $\mathrm{C} 7 \mathrm{H} 33 \mathrm{~N} 18 \mathrm{O} 10$ & 39.1 & 5.910 & 0.27 & 7 & 33 & 18 & 10 & \\
\hline & 529.2643 & 0.1 & 0.2 & 1.5 & C10 H34 N16 O8 Na & 36.8 & 3.601 & 2.73 & 10 & 34 & 16 & 8 & 1 \\
\hline & 529.2654 & -1.0 & -1.9 & -0.5 & $\mathrm{C} 11 \mathrm{H} 37 \mathrm{~N} 12 \mathrm{O} 2$ & 36.3 & 3.132 & 4.36 & 11 & 37 & 12 & 12 & \\
\hline & 529.2657 & -1.3 & -2.5 & 6.5 & $\mathrm{C} 11 \mathrm{H} 30 \mathrm{~N} 20 \mathrm{O} 4 \mathrm{Na}$ & 35.7 & 2.440 & 8.72 & 11 & 30 & 20 & 4 & 1 \\
\hline & 529.2667 & -2.3 & -4.3 & 4.5 & $\mathrm{C} 12 \mathrm{H} 33 \mathrm{~N} 16$ O8 & 36.2 & 3.027 & 4.84 & 12 & 33 & 16 & 8 & \\
\hline & 529.2670 & -2.6 & -4.9 & 0.5 & C14 H38 N10 O10 Na & 36.1 & 2.873 & 5.65 & 14 & 38 & 10 & 10 & 1 \\
\hline & 529.2622 & 2.2 & 4.2 & 7.5 & $\mathrm{C} 22 \mathrm{H} 37 \mathrm{~N} 6 \mathrm{O}$ & 37.3 & 4.100 & 1.66 & 22 & 37 & 6 & 9 & \\
\hline & 529.2625 & 1.9 & 3.6 & 14.5 & $\mathrm{C} 22 \mathrm{H} 30 \mathrm{~N} 140 \mathrm{Na}$ & 37.4 & 4.150 & 1.58 & 22 & 30 & 14 & 1 & 1 \\
\hline & 529.2635 & 0.9 & 1.7 & 12.5 & $\mathrm{C} 23 \mathrm{H} 33 \mathrm{~N} 10$ O5 & 35.8 & 2.590 & 7.50 & 23 & 33 & 10 & 5 & \\
\hline & 529.2625 & 1.9 & 3.6 & 3.5 & $\mathrm{C} 24 \mathrm{H} 42 \mathrm{O} 11 \mathrm{Na}$ & 36.5 & 3.263 & 3.83 & 24 & 42 & & 11 & 1 \\
\hline & 529.2649 & -0.5 & -0.9 & 17.5 & $\mathrm{C} 24 \mathrm{H}_{29} \mathrm{~N} 14 \mathrm{O}$ & 35.8 & 2.612 & 7.34 & 24 & 29 & 14 & 1 & \\
\hline & 529.2638 & 0.6 & 1.1 & 8.5 & $\mathrm{C} 25 \mathrm{H} 38 \mathrm{~N} 4 \mathrm{O} 7 \mathrm{Na}$ & 34.8 & 1.613 & 19.92 & 25 & 38 & 4 & 7 & 1 \\
\hline & 529.2652 & -0.8 & -1.5 & 13.5 & $\mathrm{C} 26 \mathrm{H} 34 \mathrm{~N} 803 \mathrm{Na}$ & 35.0 & 1.784 & 16.79 & 26 & 34 & 8 & 3 & 1 \\
\hline & 529.2649 & -0.5 & -0.9 & 6.5 & $\mathrm{C} 26 \mathrm{H} 41011$ & 35.4 & 2.155 & 11.58 & 26 & 41 & & 11 & \\
\hline
\end{tabular}

LN137 25 (0.279) AM2 (Ar, 10000.0,0.00,0.00); Cm (25:34)

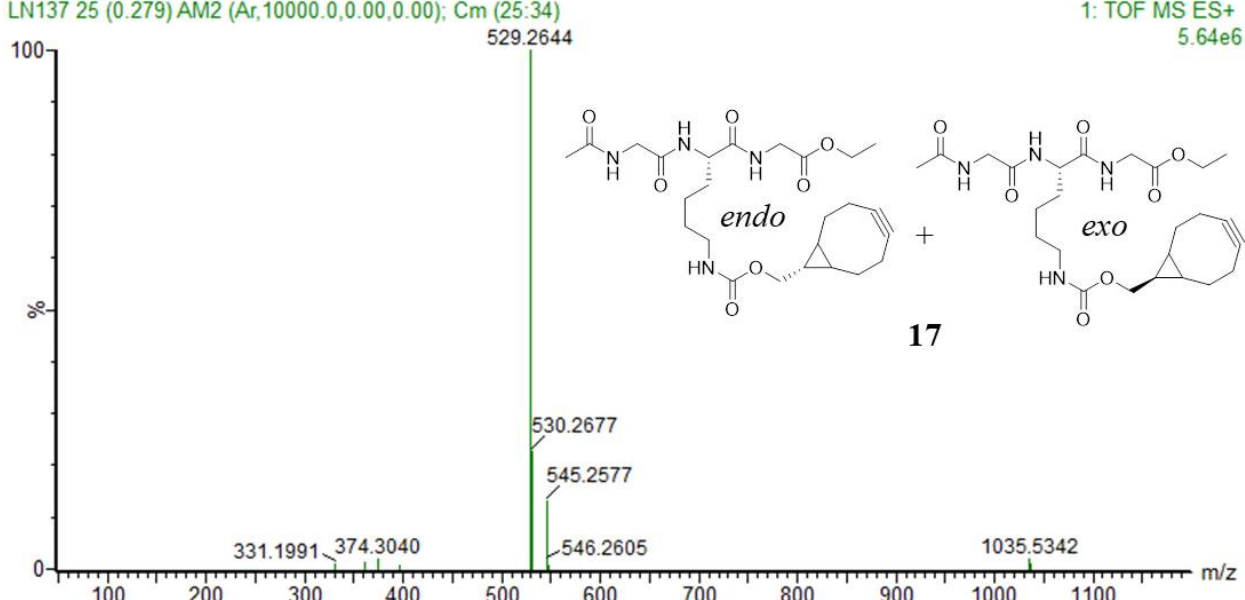

$100 \quad 200 \quad 300 \quad 400$

500

$900 \quad 1000 \quad 1100$ 

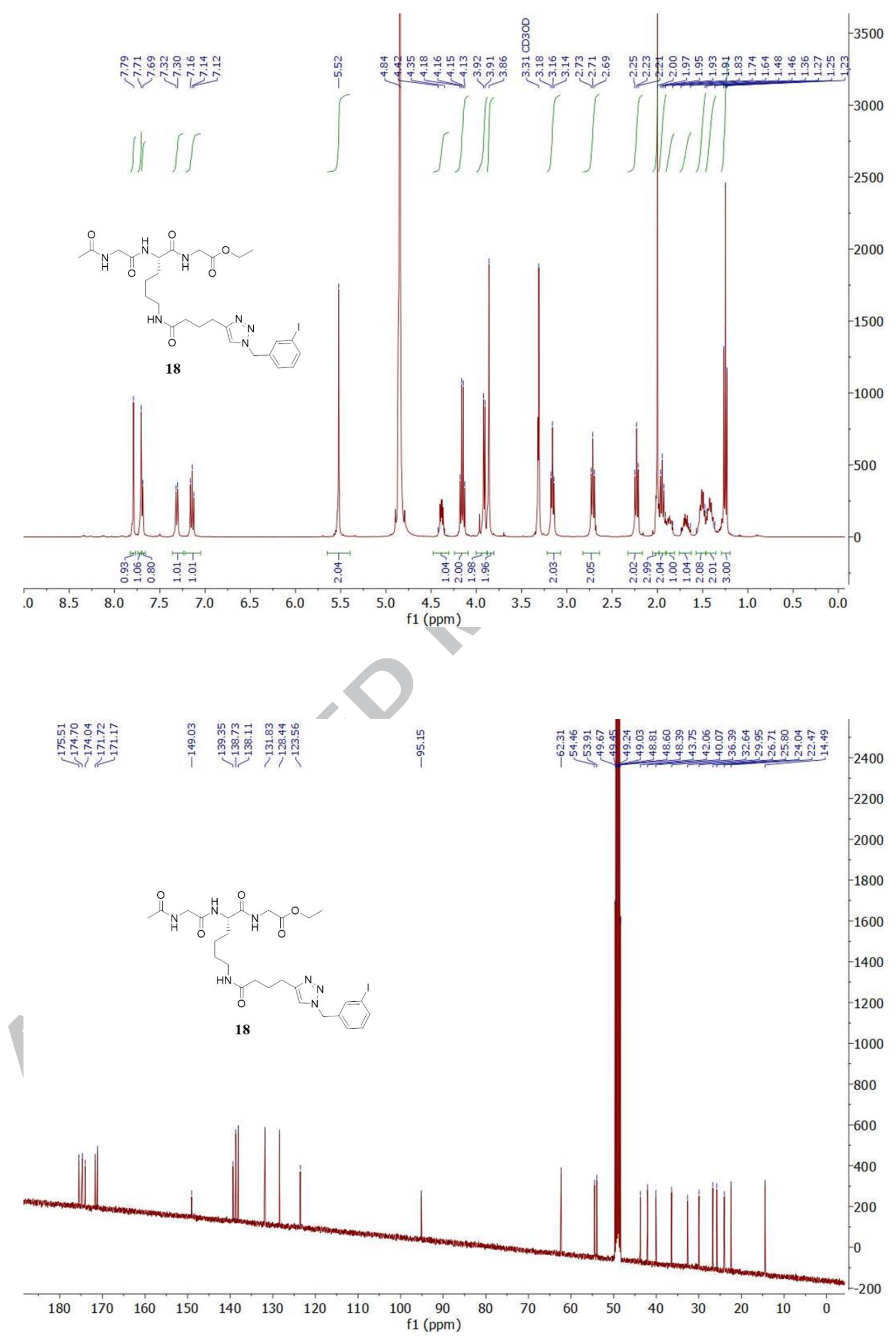


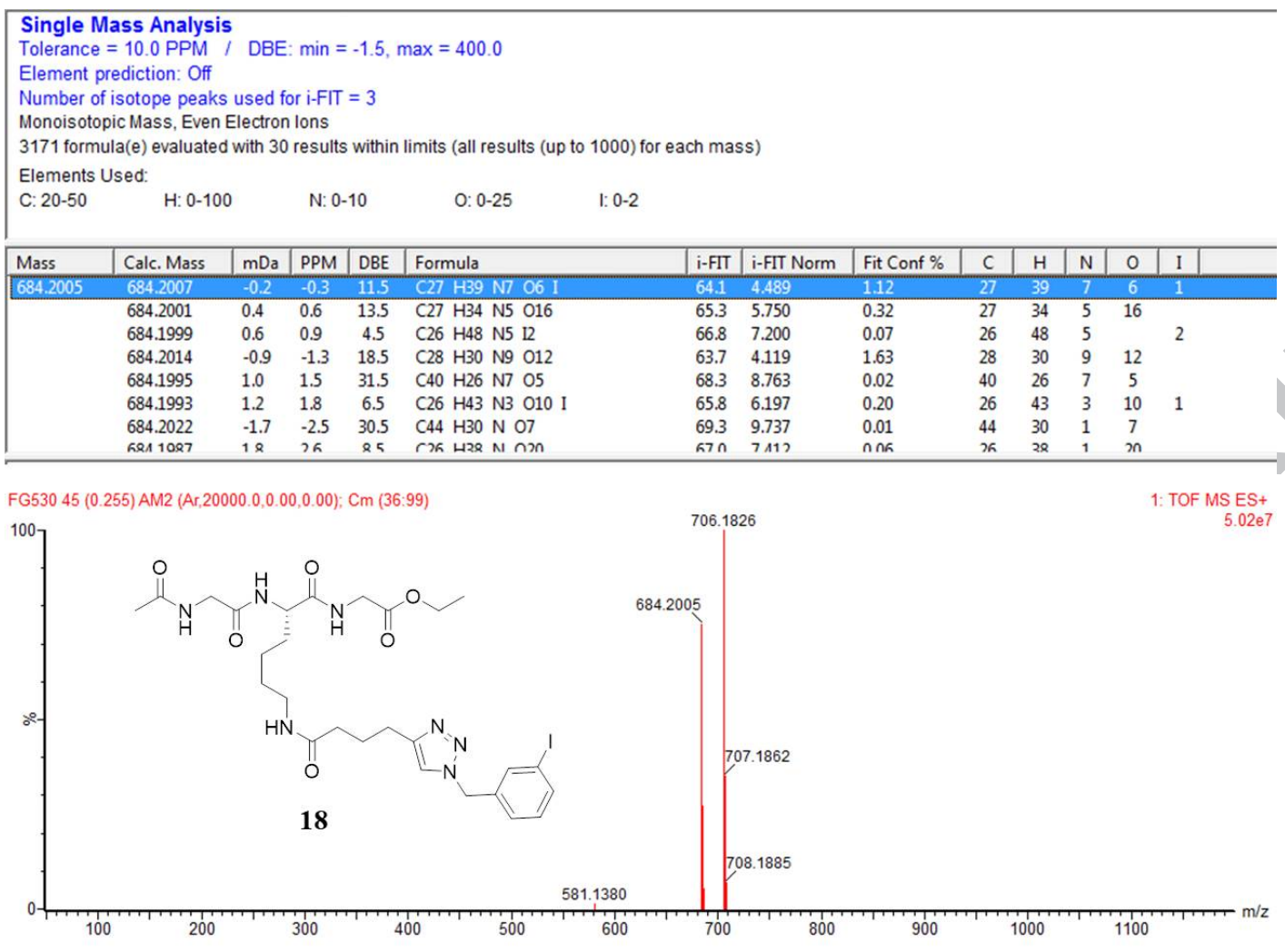




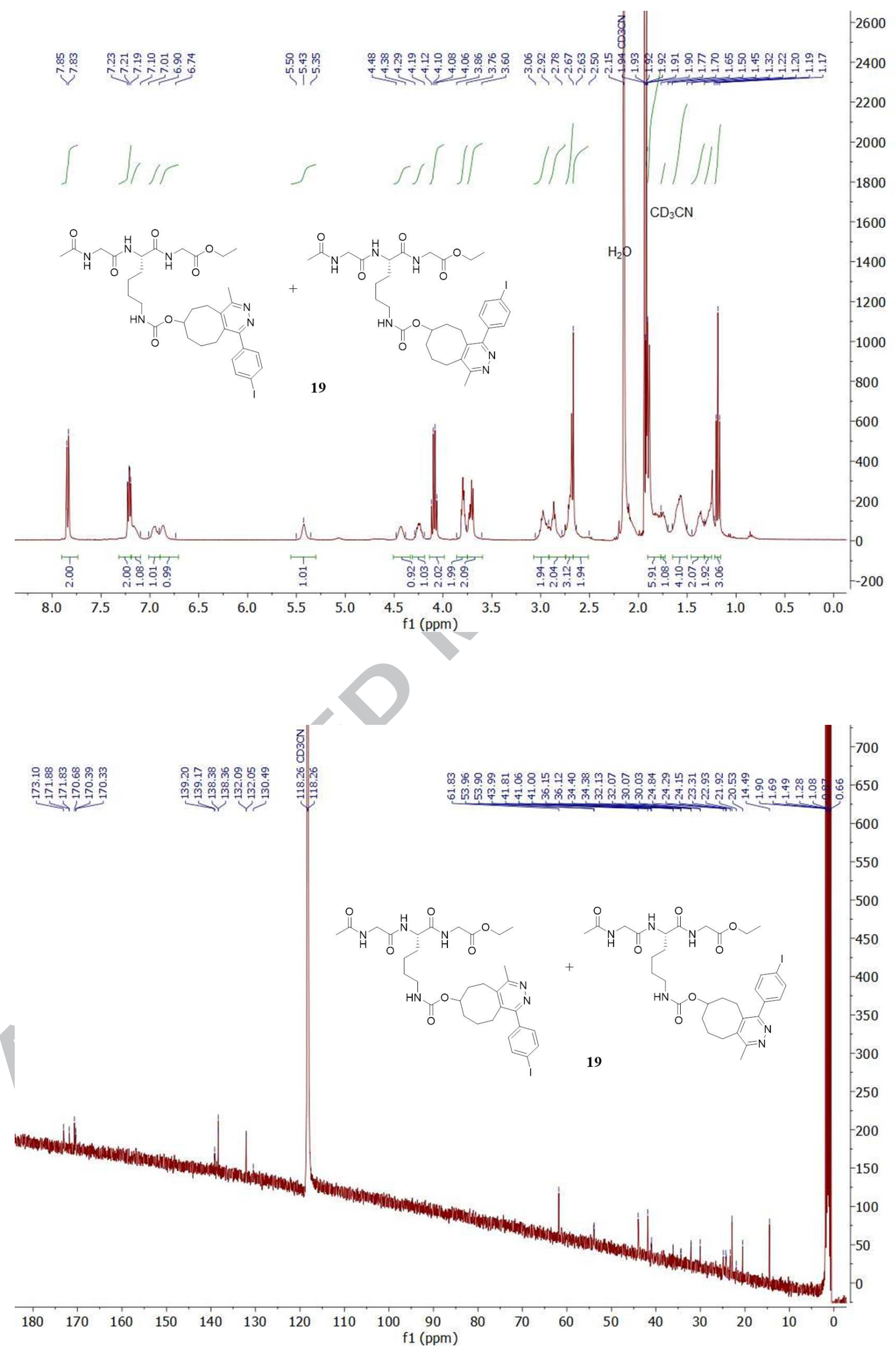




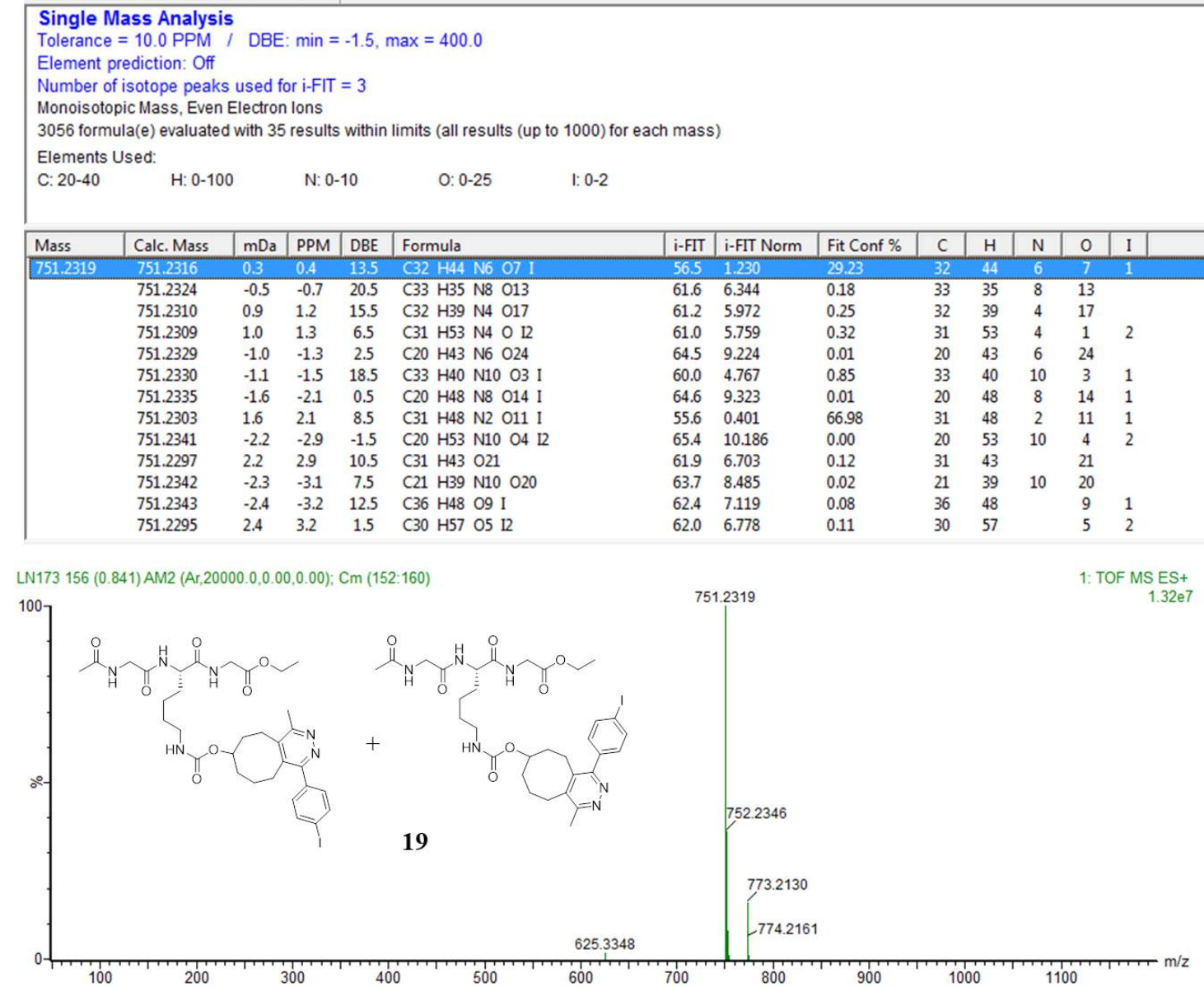



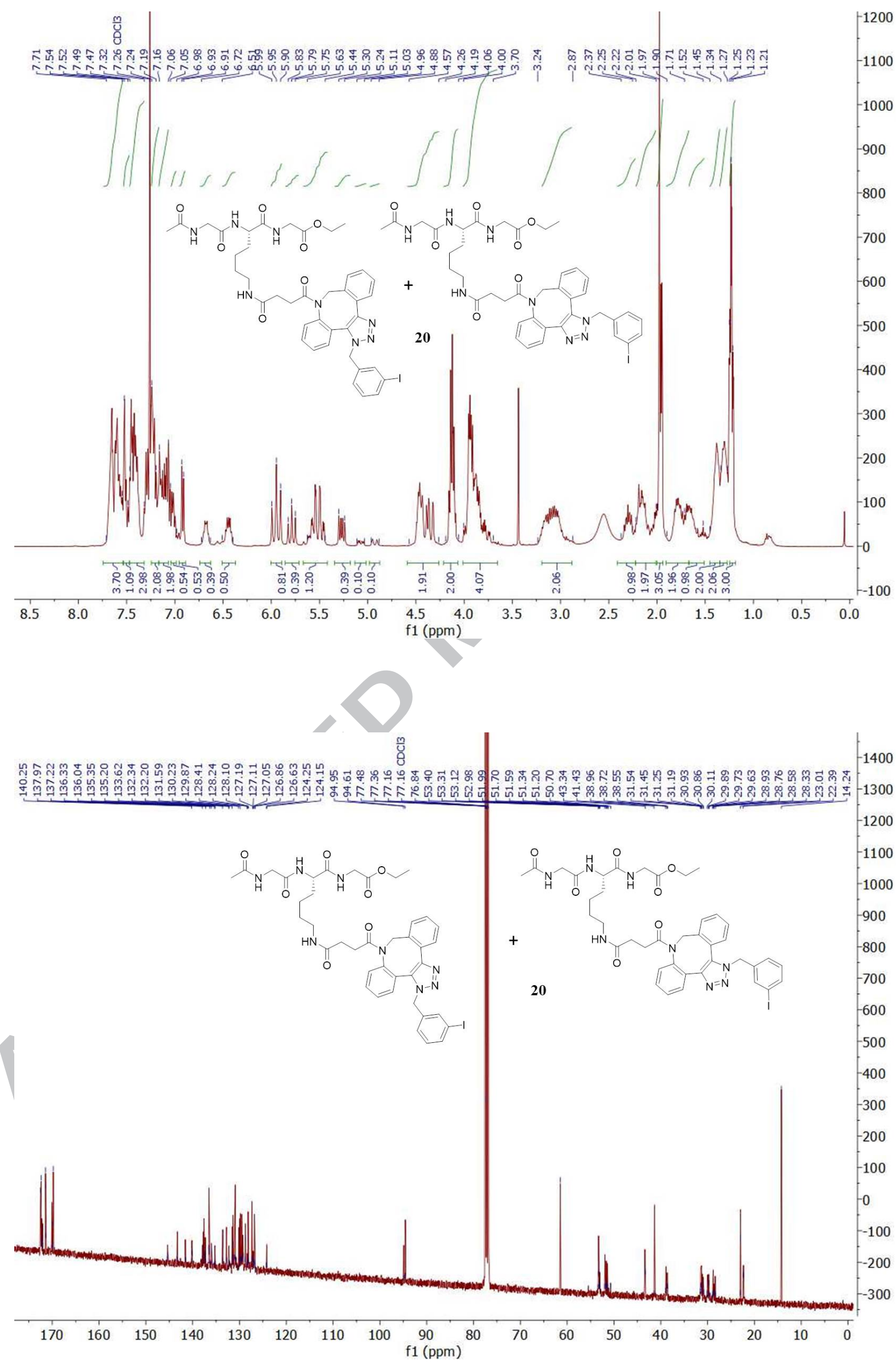


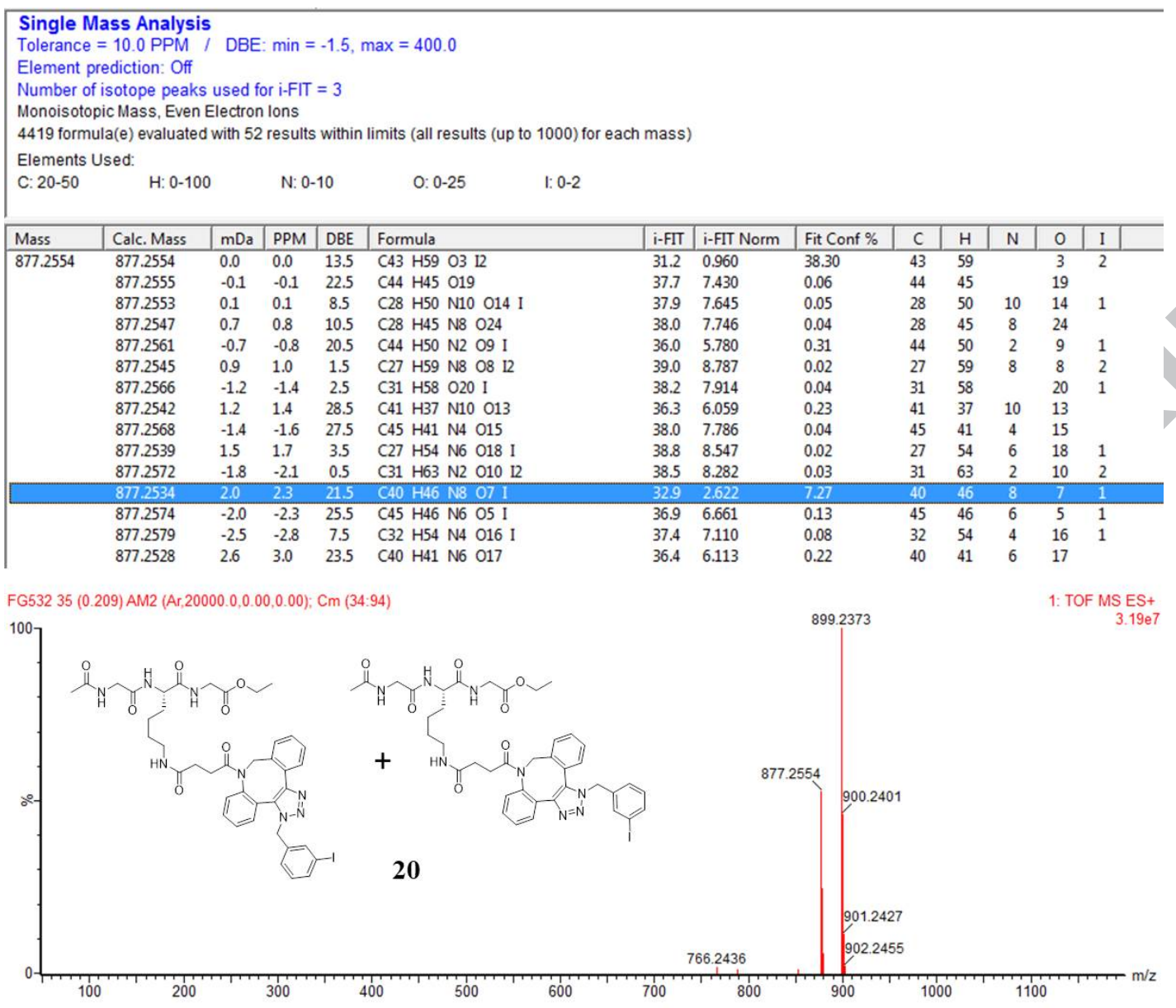



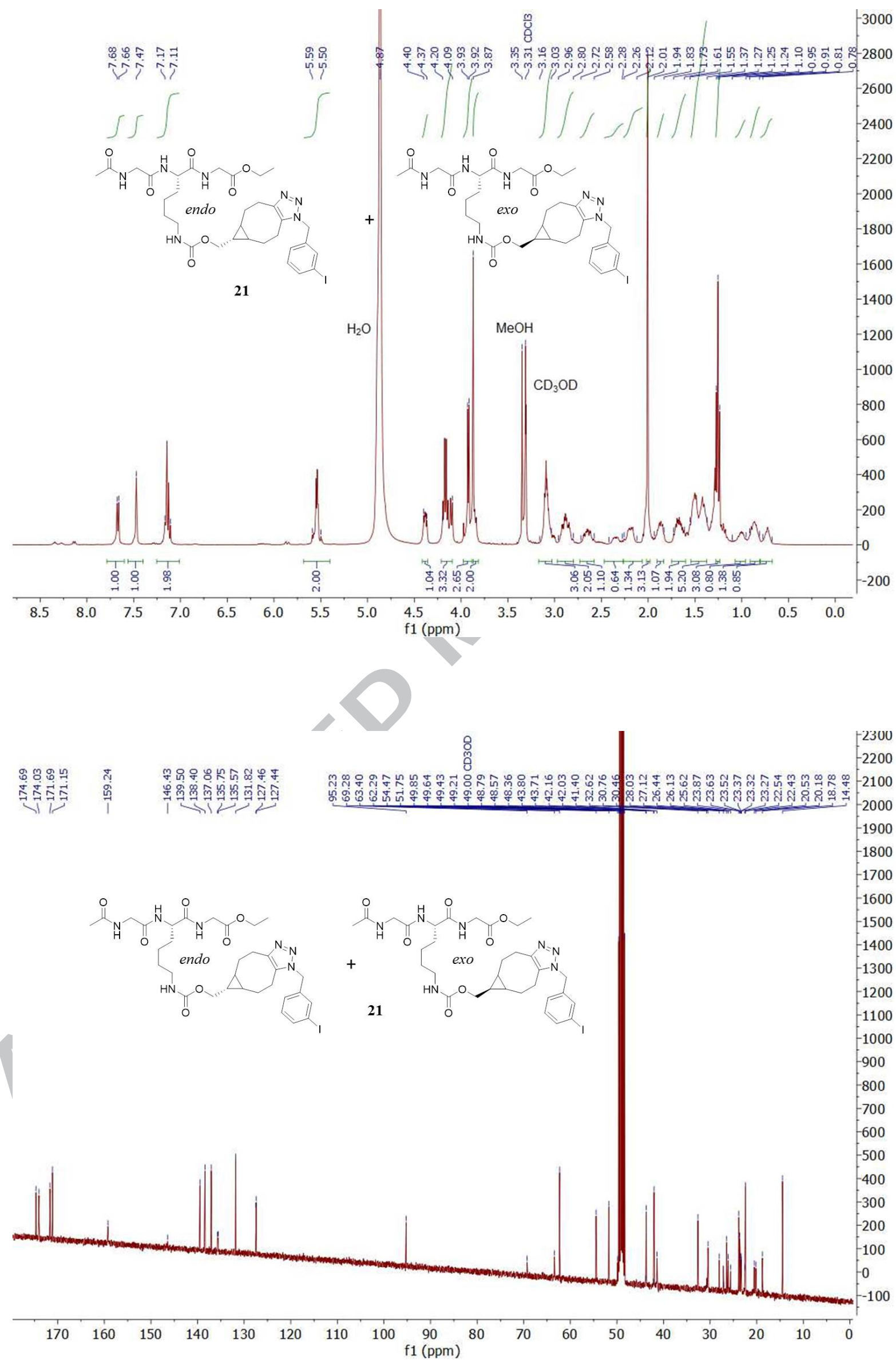


\section{Single Mass Analysis}

Tolerance $=10.0$ PPM / DBE: $\min =-1.5, \max =400.0$

Element prediction: Off

Number of isotope peaks used for i-FIT $=3$

Monoisotopic Mass, Even Electron Ions

3951 formula(e) evaluated with 37 results within limits (all results (up to 1000) for each mass)

Elements Used:

$\begin{array}{lllll}\text { C: } 20-50 \quad \mathrm{H}: 0-100 & \mathrm{~N}: 0-10 & \text { O: } 0-25 & \text { I: } 0-2\end{array}$

\begin{tabular}{|c|c|c|c|c|c|c|c|c|c|c|c|c|c|}
\hline Mass & Calc. Mass & $\mathrm{mDa}$ & PPM & DBE & Formula & i-FIT & i-FIT Norm & Fit Conf $\%$ & $\mathrm{C}$ & $\mathrm{H}$ & $\mathrm{N}$ & 0 & I \\
\hline \multirow[t]{5}{*}{766.2421} & 766.2419 & 0.2 & 0.3 & 15.5 & $\mathrm{C} 32 \mathrm{H} 40 \mathrm{N5} \mathrm{O} 17$ & 34.0 & 5.277 & 0.51 & 32 & 40 & 5 & 17 & \\
\hline & 766.2418 & 0.3 & 0.4 & 6.5 & $\mathrm{C} 31 \mathrm{H} 54$ N5 O $\mathrm{I} 2$ & 35.7 & 6.923 & 0.10 & 31 & 54 & 5 & 1 & 2 \\
\hline & 766.2425 & -0.4 & -0.5 & 13.5 & $\mathrm{C} 32 \mathrm{H} 45$ N7 $07 \mathrm{I}$ & 33.0 & 4.304 & 1.35 & 32 & 45 & 7 & 7 & 1 \\
\hline & 766.2414 & 0.7 & 0.9 & 33.5 & $\mathrm{C} 45 \mathrm{H} 32 \mathrm{~N} 7 \mathrm{O} 6$ & 37.2 & 8.462 & 0.02 & 45 & 32 & 7 & 6 & \\
\hline & 766.2412 & 0.9 & 1.2 & 8.5 & C31 H49 N3 O11 I & 34.7 & 5.959 & 0.26 & 31 & 49 & 3 & 11 & 1 \\
\hline
\end{tabular}

FG531 35 (0.209) AM2 (Ar, 20000.0,0.00,0.00); Cm (12:51)

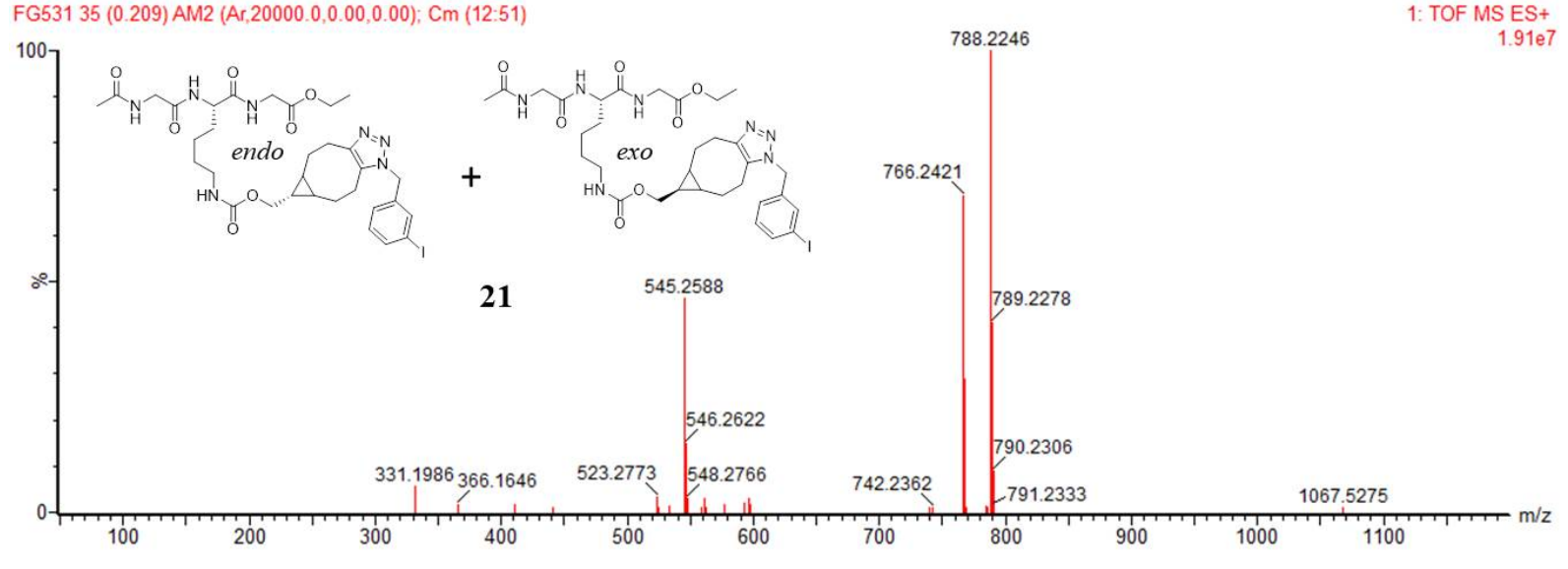




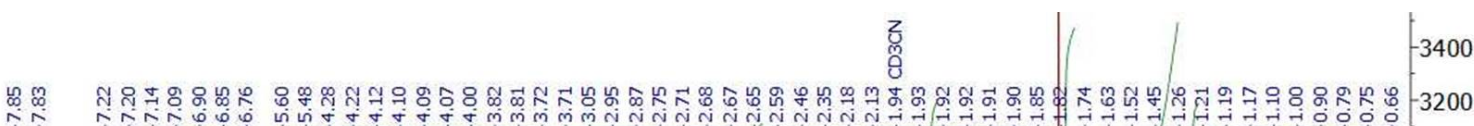

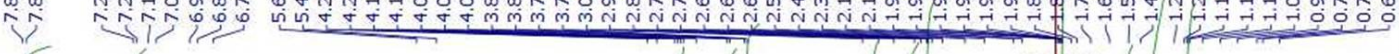

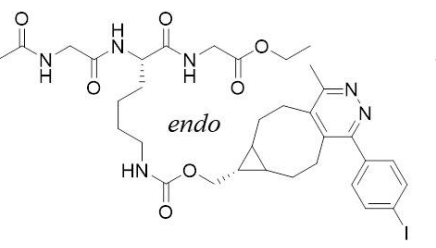

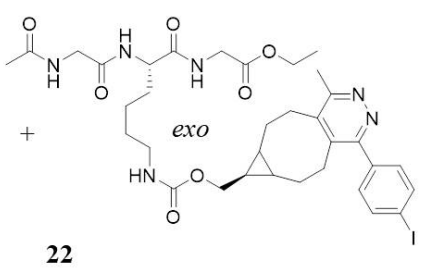

$\mathrm{H} 2 \mathrm{O}$
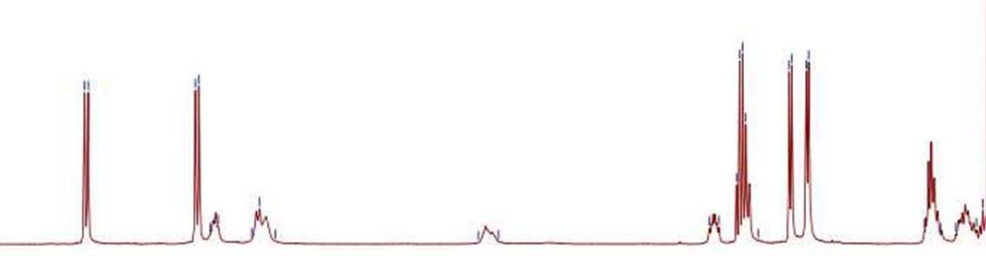

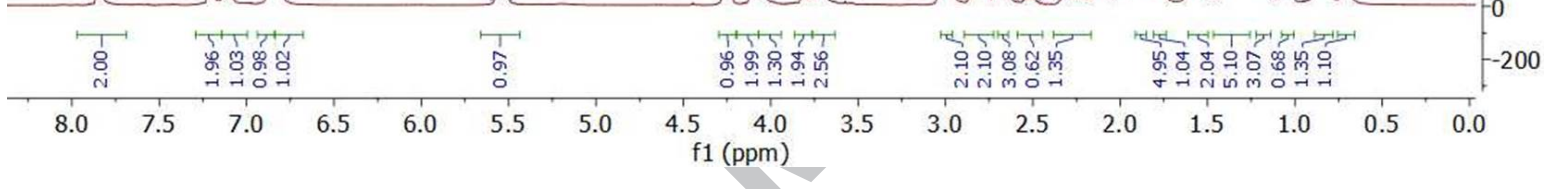

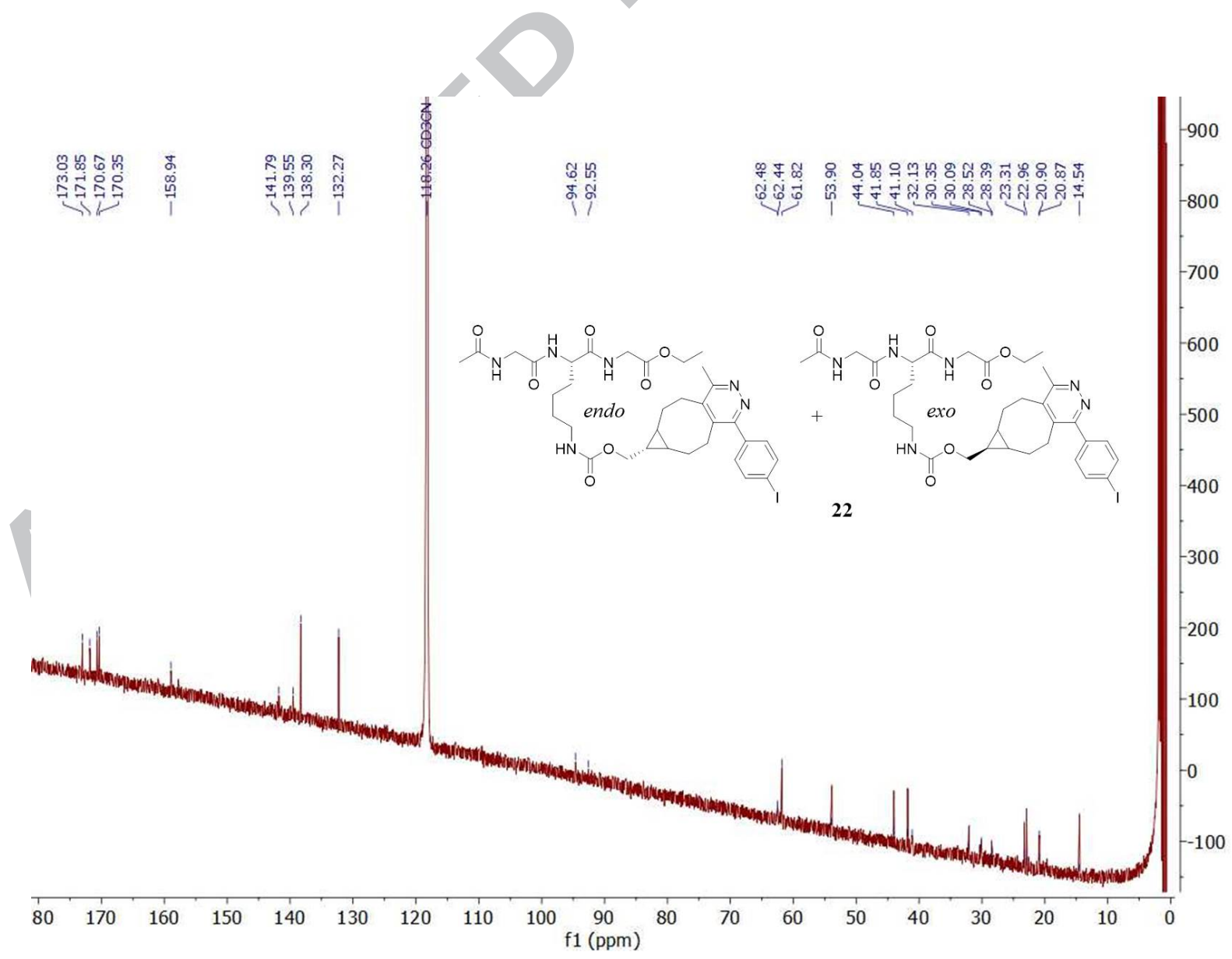



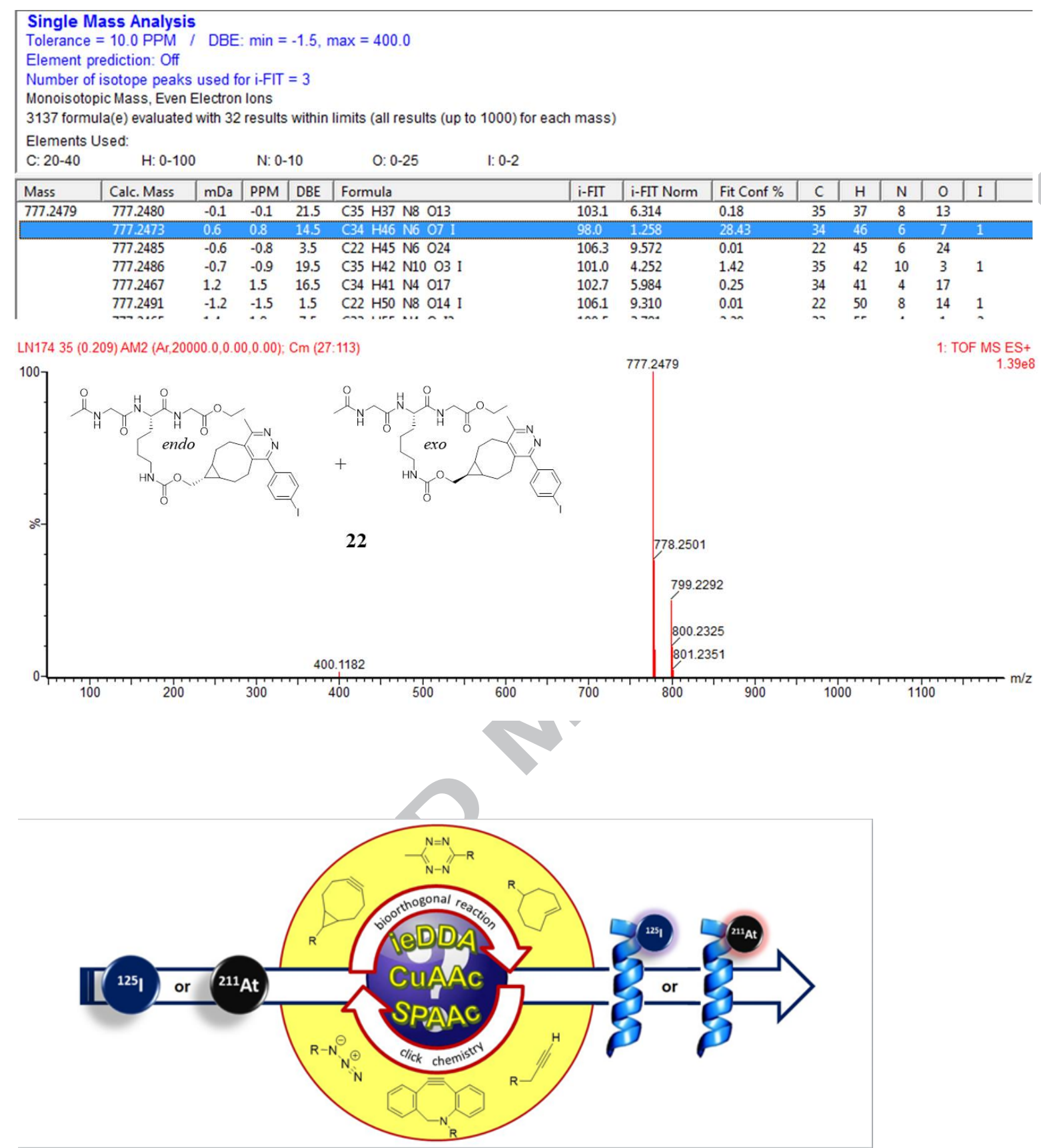